\title{
EIIIII|ESE $\begin{aligned} & \text { IESE } \\ & \text { Cities in }\end{aligned}$ Business School Motion University of Navarra
}

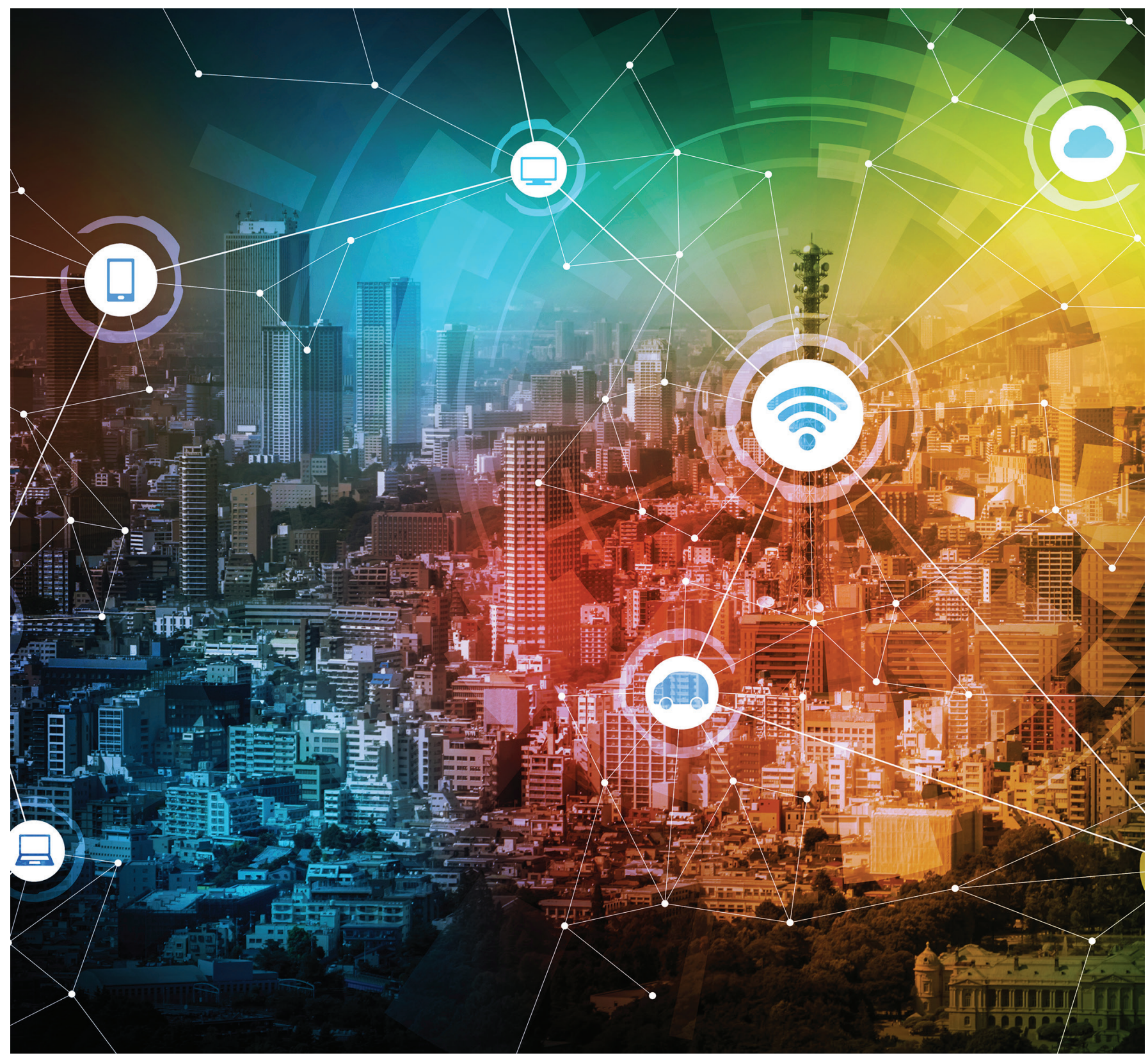

IESE Cities

in Motion Index 


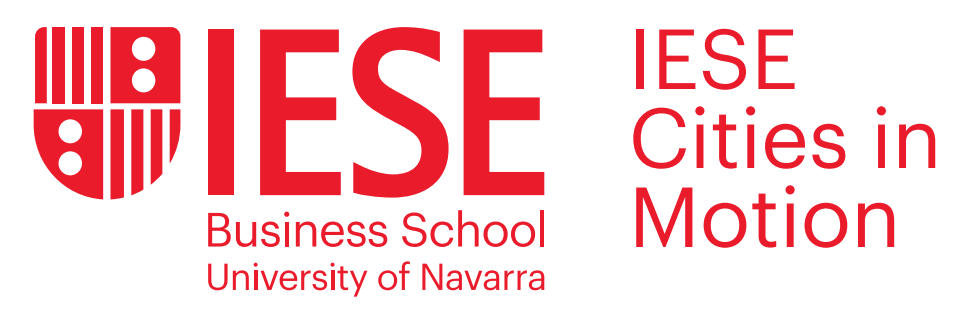

\section{IESE Cities




\section{CONTENTS}

Foreword — 07

About Us _ 09

$\begin{array}{ll}\text { Working Team _ـ } & 09\end{array}$

$\begin{array}{lr}\text { Introduction: The Need for a Global Vision } & 10\end{array}$

Our Model: Cities in Motion. Conceptual Framework, Definitions and Indicators __ 11

Limitations of the Indicators _ـ 22

Geographic Coverage _ـ 22

Cities in Motion. Ranking __ 24

Cities in Motion. Ranking by dimension __ 26

Cities in Motion. Regional Ranking __ 38

$\begin{array}{ll}\text { Noteworthy Cases __ } & 42\end{array}$

Evolution of the Cities in Motion Index __ 45

Cities in Motion Compared With Other Indexes___ 48

Cities in Motion: City Ranking by Population __ 49

Cities in Motion: Analysis of Dimensions in Pairs __ 52

Cities in Motion: A Dynamic Analysis __ 55

Recommendations and Conclusions _ـ 57

Appendix 1. Indicators _ 60

Appendix 2. Graphical Analysis of the Profiles of 165 Cities __ 66 


\section{FOREWORD}

Once again, we are pleased to present a new annual edition (the fifth) of our IESE Cities in Motion Index (CIMI). We have observed with great satisfaction how various cities, companies and other social actors have used our study to carry out a comprehensive first diagnosis and an initial benchmarking of other major cities through comparative analysis.

From its beginnings, the CIMI has aimed to improve year after year, and this fifth edition is no exception. As in previous editions, we have tried to provide an index that is objective, comprehensive, wide-ranging and guided by the criteria of conceptual relevance and statistical rigor. However, this fifth edition features some different elements with respect to previous editions. The first important difference is that we have significantly increased the number of variables at the city level. This edition includes a total of 83 indicators, which reflect both objective and subjective data and offer a comprehensive view of each city. Among the new variables, we have included, for example, ISO 37120 certification indicators, the number of terrorist attacks and the number of Apple stores in each city. In addition, we have incorporated prospective variables, such as the projections of GDP per capita or forecast temperature readings resulting from climate change. We believe that this increase in the quantity and quality of the variables used allows for a more accurate assessment of the reality of the cities included in our index.

The cost of this improvement in indicators is reflected in the inclusion of a smaller number of cities compared to the previous edition. Despite this, this edition includes 165 cities - 74 of them capitals - which represent a total of 80 countries. In this regard, a second difference compared to previous editions is that 13 new cities have been incorporated, including Reykjavik (Iceland), Bern (Switzerland), Wellington (New Zealand) and San Diego (USA), among others. The breadth and scope of the CIMI establishes it as one of the city indexes with the widest geographical coverage available today.

The third different element of this edition is the merging of two dimensions of our conceptual model, which originally took into account 10 key dimensions: human capital, social cohesion, the economy, public management, governance, the environment, mobility and transportation, urban planning, international outreach and technology. We have merged "governance" with "public management" (in a dimension called simply "governance") for two fundamental reasons. In the first place, there is a certain overlap between both dimensions that makes it difficult to distinguish between them conceptually. Secondly, the limited number of indicators at the city level that cover these dimensions led us to merge them to ensure we have a more reliable measure. We believe that this change does not significantly affect the conclusions of the CIMI but rather it makes them more robust. In any case, we continue to work to obtain more and better indicators to capture these dimensions.

We see this work as a dynamic project and therefore we continue to work so that the future editions of the index will have the best indicators and give wider coverage and a growing analytical and predictive value. Your comments and suggestions are welcome, as they will enable us to improve. Therefore, we invite you to get in touch with the platform through our website: www.iese.edu/cim.

We would like to inform our readers that our efforts here at the IESE Cities in Motion platform have not been limited to just ranking cities. We have continued to publish our series of "minibooks" in English, which identify good practices in each of the dimensions of the IESE Cities in Motion model. Currently there are four books available on Amazon on good practices for the dimensions 
of "the environment," "mobility and transportation," "the economy" and "social cohesion." This collection will be expanded shortly to cover the rest of our model's dimensions, with "international outreach" being the next volume in the series.

Moreover, new case studies have been published in addition to those that already exist on the cities of Vancouver (Vancouver: The Challenge of Becoming the Greenest City) and Barcelona (A Roman Village Becoming a Smart City). During this academic year we have written a case study on the city of Málaga entitled Málaga: In Search of Its Identity as a Smart City and a case study on the city of Medellín, whose provisional title is Medellín's Transformation: Toward a More Equitable, Innovative and Participatory Urban Society. These cases are available on the IESE case study portal (www.iesep.com) and there will soon be new cases available, including one dedicated to the city of Singapore and its "digital identity" project. As well as these publications, several academic papers have been published in prestigious journals such as the Academy of Management Journal, the California Management Review and the Harvard Deusto Business Review. Finally, we have strengthened the presence of the IESE Cities in Motion platform on the Internet with our Twitter account (@iese_cim) and our monthly posts on the IESE Cities in Motion blog (blog.iese. edu/cities-challenges-and-management/).

We regard our publications and our presence in cyberspace as being the ideal complements of this index as they contribute to a better understanding of the reality of cities. Therefore, we believe that it will be useful for those in charge of making our cities better environments in which to live, work and enjoy life. Urban managers face significant obstacles such as difficulties in mobility, aging populations, increases in inequality, the persistence of poverty and pollution, among many other challenges. The scope and magnitude of these challenges demonstrate the need for the world's cities to undertake a strategic review process that covers: what type of city they want to be, what their priorities are, and what process of change they will adopt in order to take advantage of the opportunities - and minimize the threats - of urbanization. This report is our humble contribution to advancing this process. We are convinced that we can live in better cities, but this will be possible only if all the social actors - the public sector, private companies, civic organizations and academic institutions - contribute and collaborate to achieve this common goal.

\section{THE AUTHORS}

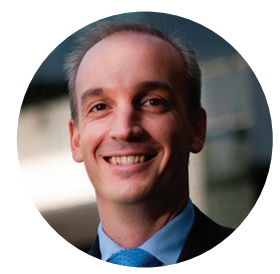

Prof. Pascual Berrone

Holder of the Schneider Electric

Sustainability and Business

Strategy Chair

Academic codirector of IESE Cities in Motion Strategies

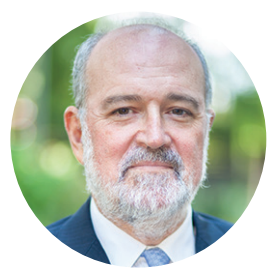

Prof. Joan Enric Ricart

Holder of the Carl Schrøder

Chair of Strategic Management

Academic codirector of

IESE Cities in Motion Strategies

*You will find a complete list of publications on the website www.iese.edu/cim. 


\section{ABOUT US}

IESE Cities in Motion Strategies is a research platform launched jointly by the Center for Globalization and Strategy and IESE Business School's Department of Strategy.

The initiative connects a global network of experts in cities and specialist private companies with local governments from around the world. The aim is to promote changes at the local level and to develop valuable ideas and innovative tools that will lead to more sustainable and smarter cities.

The platform's mission is to promote the Cities in Motion model, with an innovative approach to city governance and a new urban model for the 21st century based on four main factors: sustainable ecosystem, innovative activities, equality among citizens, and connected territory.

\section{WORKING TEAM}

\section{ACADEMIC TEAM}

\section{Prof. Pascual Berrone}

Holder of the Schneider Electric Sustainability and

Business Strategy Chair

\section{Prof. Joan Enric Ricart}

Holder of the Carl Schrøder Chair of Strategic

Management

\section{Carlos Carrasco}

Research Collaborator

\section{Ana Isabel Duch T-Figueras}

Research Collaborator

\section{TECHNICAL TEAM}

\section{David Augusto Giuliodori}

Econfocus Consulting

\section{María Andrea Giuliodori}

Professor of statistics at the Institute of Stock Exchange Studies (IEB) 


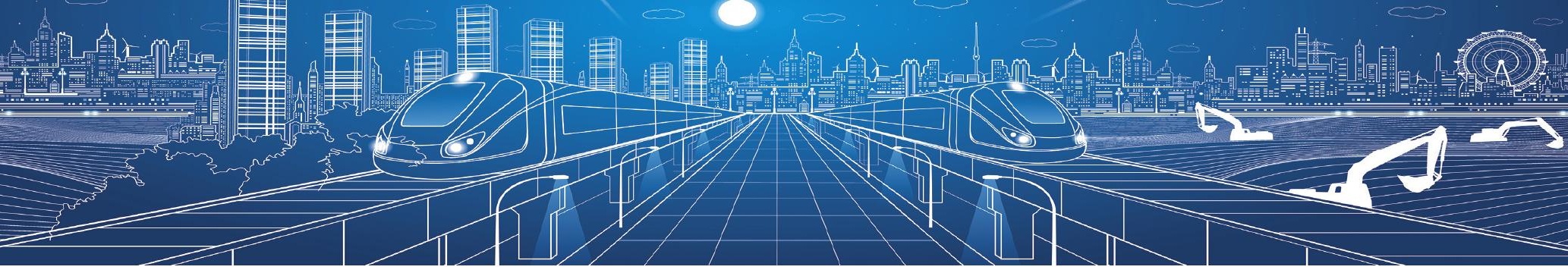

\section{INTRODUCTION: THE NEED FOR A GLOBAL VISION}

Today more than ever, cities need to develop strategic planning processes, since only then can they outline paths toward innovation and prioritize the aspects that are most important for their future.

The strategic planning process should be participatory and flexible, and a central aim should be established: to define a sustainable action plan that will make the metropolis unique and renowned. Just as two companies do not have the same recipe for success, each city must look for its own model based on a series of common reflections and considerations.

Experience shows that cities must eschew short-termism and broaden their field of view. They should turn to innovation more frequently to improve the efficiency and sustainability of their services. Also, they should promote communication and ensure that the public and businesses are involved in their projects.

The time has come to practice smart governance that takes into account all the factors and social actors in a global vision. In fact, over the past few decades, various national and international organizations have produced studies focusing on the definition, creation and use of indicators with a variety of aims, although mainly to contribute to a diagnosis of the state of cities. The definition of the indicators and the process of their creation are the result of the characteristics of each study, the statistical and econometric techniques that best fit the theoretical model and the available data, as well as the analysts' preferences.

Today we have a great deal of "urban" indicators, although many of them are neither standardized nor consistent and they cannot be used to compare cities. In fact, despite numerous attempts to develop city indicators at a national, regional and international level, few have been sustainable in the medium term, as they were created for studies meant to cover the specific in- formation needs of certain bodies, whose lifespan depended on how long the financing would last. In other cases, the system of indicators depended on a political desire in specific circumstances, so they were abandoned when political priorities or the authorities themselves changed. As for the indicators developed by international organizations, it is true that they strive for the consistency and solidity necessary to compare cities; however, for the most part, they tend to be biased or focused on a particular area (technology, the economy, and the environment, among others).

Taking all this into account, the Cities in Motion Index (CIMI) has been designed with the aim of constructing a "breakthrough" indicator in terms of its completeness, characteristics, comparability and the quality and objectivity of its information. Its goal is to enable measurement of the future sustainability of the world's main cities as well as the quality of life of their inhabitants.

The $\mathbf{C I M I}$ is intended to help the public and governments to understand the performance of nine fundamental dimensions for a city: human capital, social cohesion, the economy, governance, the environment, mobility and transportation, urban planning, international outreach, and technology. All the indicators are linked with a strategic aim that leads to a novel form of local economic development: the creation of a global city, the promotion of the entrepreneurial spirit, and innovation, among other aspects.

Each city is unique and unrepeatable and has its own needs and opportunities, so it must design its own plan, set its priorities, and be flexible enough to adapt to changes.

Smart cities generate numerous business opportunities and possibilities for collaboration between the public and private sectors. All stakeholders can contribute, so an ecosystem network must be developed that will involve all of them: members of the public, organizations, institutions, government, universities, experts, research centers, etc.

Networking has its advantages: better identification of the needs of the city and its residents, the establishment of common aims and constant communication among participants, the expansion of learning opportunities, increased transparency, and the implementation of more flexible public policies. As a report by the Organization- 
for Economic Cooperation and Development (OECD) pointed out back in 2001, the network approach allows local policies to be focused on the public.

Private enterprise also has much to gain with this system of networking: it can collaborate with the administration in the long term, access new business opportunities, gain a greater understanding of the needs of the local ecosystem, gain greater international visibility and attract talent.

Thanks to its technical expertise and its experience in project management, private enterprise, in collaboration with universities and other institutions, is suited to lead and develop smart city projects. In addition, it can provide efficiency and result in significant savings for public-private bodies.

Finally, it must not be forgotten that the human factor is fundamental in the development of cities. Without a participatory and active society, any strategy, albeit intelligent and comprehensive, will be doomed to failure. Beyond technological and economic development, it is the public that holds the key for cities to go from "smart" to "wise." That is precisely the goal to which every city should aspire: that the people who live there and their rulers deploy all their talent in favor of progress.

To help cities identify effective solutions, we have created an index that integrates nine dimensions in a single indicator and covers 165 cities worldwide. Thanks to its broad and integrated vision of the city, the Cities in Motion Index enables the strengths and weaknesses of each city to be identified.

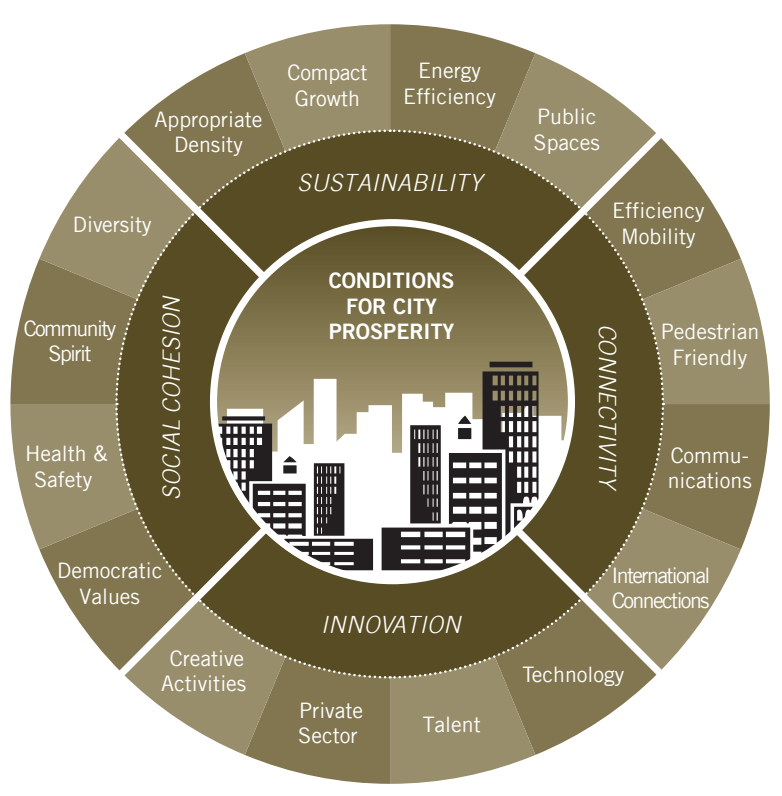

OUR MODEL:

CITIES IN MOTION. CONCEPTUAL FRAMEWORK, DEFINITIONS AND INDICATORS

Our platform proposes a conceptual model based on the study of a large number of success stories and a series of in-depth interviews with city leaders, entrepreneurs, academics and experts linked to the development of cities.

Our model proposes a set of steps that include diagnosis of the situation, the development of a strategy, and its subsequent implementation. The first step to giving a good diagnosis is to analyze the status of the key dimensions, which we will set out below along with the indicators used to calculate the CIMI.

\section{HUMAN CAPITAL}

The main goal of any city should be to improve its human capital. A city with smart governance must be capable of attracting and retaining talent, of creating plans to improve education, and of promoting creativity and research.

Table 1 sets out the indicators used in the human capital dimension, along with their descriptions, units of measurement, and information sources.

While human capital includes factors that make it more extensive than what can be measured with these indicators, there is international consensus that level of education and access to culture are irreplaceable components for measuring human capital. One of the pillars of human development is human capital and, given that the Human Development Index published annually by the United Nations Development Program (UNDP) includes education and culture as dimensions, it is valid to regard these indicators as factors explaining the differences in human capital in a city.

To define the human capital dimension, the CIMI includes the nine variables detailed in Table 1 . All these variables are incorporated into the index with a positive sign due to their contribution to the development of the dimension. 


\section{TABLE 1. HUMAN CAPITAL INDICATORS}

\begin{tabular}{|c|c|c|c|}
\hline NO. & INDICATOR & DESCRIPTION / UNIT OF MEASUREMENT & SOURCE \\
\hline 1 & Higher education & Proportion of population with secondary and higher education. & Euromonitor \\
\hline 2 & Business schools & Number of business schools (top 100). & Financial Times \\
\hline 3 & Movement of students & International movement of higher-level students. Number of students. & UNESCO \\
\hline 4 & Universities & Number of universities in the city that are in the top 500. & QS Top Universities \\
\hline 5 & Museums and art galleries & Number of museums and art galleries per city. & OpenStreetMap \\
\hline 6 & Schools & Number of public or private schools per city. & OpenStreetMap \\
\hline 7 & Theaters & Number of theaters per city & OpenStreetMap \\
\hline 8 & $\begin{array}{l}\text { Expenditure on leisure and } \\
\text { recreation }\end{array}$ & Expenditure on leisure and recreation per capita. & Euromonitor \\
\hline 9 & $\begin{array}{l}\text { Expenditure on leisure and } \\
\text { recreation }\end{array}$ & Expenditure on leisure and recreation. In millions of dollars. & Euromonitor \\
\hline
\end{tabular}

To measure access to culture, the number of museums, art galleries and theaters and the expenditure on leisure and recreation are taken into account. These indicators show the city's commitment to culture and human capital. Cities that are considered creative and dynamic on a global level typically have museums and art galleries open to the public, offer visits to art collections, and carry out activities aimed at the conservation of art. The existence of a city's cultural and recreation provision results in greater expenditure on these activities by the population.

\section{SOCIAL COHESION}

Social cohesion is a sociological dimension of cities that can be defined as the degree of consensus among the members of a social group or as the perception of belonging to a common situation or project. It is a measure of the intensity of social interaction within the group. Social cohesion in the urban context refers to the degree of coexistence among groups of people with different incomes, cultures, ages, and professions who live in a city. Concern about the city's social setting requires an analysis of factors such as immigration, community development, care of the elderly, the effectiveness of the health system, and public inclusion and safety.

The presence of various groups in the same space and mixing and interaction between groups are essential in a sustainable urban system. In this context, social cohesion is a state in which citizens and the government share a vision of a society based on social justice, the primacy of the rule of law, and solidarity. This allows us to understand the importance of policies that foment and reinforce social cohesion based on democratic values.
Table 2 sets out the indicators selected for this dimension, descriptions of them, their units of measurement and the sources of information. This selection of indicators seeks to incorporate all the sociological subdimensions of social cohesion, taking into account the different variables available.

The ratio of deaths per 100,000 inhabitants and the crime rate are incorporated with a negative sign, while the health index is incorporated with a positive sign when creating this dimension. Furthermore, both the health index and the number of public and private hospitals and health centers per city are added with a positive sign, since access to and coverage provided by basic social services help strengthen social cohesion.

Employment, meanwhile, is a fundamental aspect in societies, to the extent that, according to historical evidence, a lack of employment can break the consensus or the implicit social contract. For this reason, the unemployment rate is incorporated with a negative sign in the dimension of social cohesion. For its part, the ratio of women who work in public administration is incorporated with a positive sign, since it is an indicator of gender equality in access to government jobs.

The Gini index is calculated from the Gini coefficient and measures social inequality. It assumes a value equal to 0 for situations in which there is a perfectly equitable distribution of income (everyone has the same income) and it assumes a value equal to 100 when the income distribution is completely unequal (one person has all the income and the others nothing). This indicator is included in the dimension with a negative sign, since a 


\section{TABLE 2. SOCIAL COHESION INDICATORS}

\begin{tabular}{|c|c|c|c|}
\hline NO. & INDICATOR & DESCRIPTION / UNIT OF MEASUREMENT & SOURCE \\
\hline 10 & Mortality & Ratio of deaths per 100,000 inhabitants. & Euromonitor \\
\hline 11 & Crime rate & Crime rate. & Numbeo \\
\hline 12 & Health & Health index. & Numbeo \\
\hline 13 & Unemployment & Unemployment rate (number of unemployed out of the workforce). & Euromonitor \\
\hline 14 & Gini index & $\begin{array}{l}\text { Measure of social inequality. It varies from } 0 \text { to } 100 \text {, with zero being a } \\
\text { situation of perfect equality and } 100 \text { that of perfect inequality. }\end{array}$ & Euromonitor \\
\hline 15 & Price of property & Price of property as percentage of income. & Numbeo \\
\hline 16 & Female workers & Ratio of female workers in the public administration. & $\begin{array}{l}\text { International Labour } \\
\text { Organization }\end{array}$ \\
\hline 17 & Global Peace Index & $\begin{array}{l}\text { An index that measures the peacefulness and the absence of violence } \\
\text { in a country or region. High values indicate countries with a high level of } \\
\text { violence. }\end{array}$ & $\begin{array}{l}\text { Institute for Economics } \\
\text { and Peace }\end{array}$ \\
\hline 18 & Hospitals & Number of public and private hospitals and health centers per city & OpenStreetMap \\
\hline 19 & Happiness index & $\begin{array}{l}\text { Happiness index of a country. The highest values on the index indicate } \\
\text { countries that have a higher degree of overall happiness. }\end{array}$ & $\begin{array}{l}\text { World Happiness } \\
\text { Index }\end{array}$ \\
\hline 20 & Global Slavery Index & $\begin{array}{l}\text { Ranking that considers the proportion of people in a situation of slavery } \\
\text { in the country. The countries occupying the top positions in the ranking } \\
\text { are those with the highest proportion of the population in a situation of } \\
\text { slavery. }\end{array}$ & Walk Free Foundation \\
\hline 21 & $\begin{array}{l}\text { Government response to } \\
\text { situations of slavery }\end{array}$ & $\begin{array}{l}\text { This variable measures how the government deals with situations of } \\
\text { slavery in the country. The top positions in the ranking indicate countries } \\
\text { that have a more effective and comprehensive response to slavery. }\end{array}$ & Walk Free Foundation \\
\hline 22 & Terrorism & Number of terrorist acts of vandalism by city in the previous three years. & $\begin{array}{l}\text { Global Terrorism } \\
\text { Database, University of } \\
\text { Maryland }\end{array}$ \\
\hline
\end{tabular}

greater Gini coefficient has a negative effect on a city's social cohesion.

The Global Peace Index is an indicator that represents the degree of tranquility and peace in a country or region, as well as the absence of violence and war. It includes internal variables such as violence and crime and external ones, such as military spending and the wars in which the country is taking part. The countries at the top of the ranking are countries with a low level of violence, so the indicator has a negative relationship with the CIMI.

The price of property as a percentage of income is also negatively related since, when the percentage of income to be used to buy a property increases, the incentives to belong to a particular city's society decrease.

Happiness is increasingly considered a suitable measure of social progress and has become a goal of government policies. According to the World Happiness Report, people consider themselves happy if they have a stable job and are healthy and if there is a more homo- geneous distribution of wealth within the country or city where they live. To represent this degree of satisfaction, the happiness index of a country has been included. This variable is considered positive, since the countries that show themselves to be "happiest" (with high index values) are those that pay special attention to freedom, employment, health care, income and good governance. Thus, the happiness of a country or city would also be reflected in greater social coexistence.

This year, two new variables related to slavery have been incorporated: the proportion of people living in slavery and the measures that governments take to respond to this type of crime. Both variables are incorporated with a negative sign in the ranking, since they do not contribute to the development of a just and socially cohesive city.

Finally, a variable for terrorist acts of vandalism by city, committed in the previous three years, has been included. This variable is incorporated with a negative sign since this type of act undermines the social peace of the city. 


\section{TABLE 3. ECONOMIC INDICATORS}

\begin{tabular}{|c|c|c|c|}
\hline NO. & INDICATOR & DESCRIPTION / UNIT OF MEASUREMENT & SOURCE \\
\hline 23 & Productivity & $\begin{array}{l}\text { Labor productivity calculated as GDP per working population (in } \\
\text { thousands). }\end{array}$ & Euromonitor \\
\hline 24 & Time required to start a business & Number of calendar days needed so a business can operate legally. & World Bank \\
\hline 25 & Ease of starting a business & $\begin{array}{l}\text { The top positions in the ranking indicate a more favorable regulatory } \\
\text { environment for creating and developing a local company. }\end{array}$ & World Bank \\
\hline 26 & Headquarters & Number of headquarters of publicly traded companies. & $\begin{array}{l}\text { Globalization and World } \\
\text { Cities (GaWC) }\end{array}$ \\
\hline 27 & $\begin{array}{l}\text { Motivation for early-stage } \\
\text { entrepreneurial activity }\end{array}$ & $\begin{array}{l}\text { Percentage of people involved in total entrepreneurial activity (TEA) } \\
\text { who are motivated by an opportunity for improvement, divided by the } \\
\text { percentage of TEA motivated by need. Total entrepreneurial activity (TEA): } \\
\text { new entrepreneurs or owners/managers of a new business }\end{array}$ & $\begin{array}{l}\text { Global } \\
\text { Entrepreneurship } \\
\text { Monitor (GEM) }\end{array}$ \\
\hline 28 & GDP estimate & Estimated annual GDP growth & Euromonitor \\
\hline 29 & GDP & Gross domestic product in millions of dollars at 2015 prices. & Euromonitor \\
\hline 30 & GDP per capita & Gross domestic product per capita. & Euromonitor \\
\hline
\end{tabular}

\section{ECONOMY}

This dimension includes all those aspects that promote the economic development of a territory: local economic development plans, transition plans, strategic industrial plans, and cluster generation, innovation and entrepreneurial initiatives.

The indicators used to represent the performance of cities in the economic dimension are specified in Table 3, along with brief descriptions, units of measurement, and information sources.

Considering that the $\mathbf{C I M I}$ seeks to measure, via multiple dimensions, sustainability in the future of the world's main cities and the quality of life of their inhabitants, real GDP is a measure of the city's economic power and of its inhabitants' income. Indeed, in numerous studies, GDP is considered the only or the most important measure of the performance of a city or country. However, in this report, it is not considered as exclusive nor as the most important measure but as one more indicator within the framework of the nine dimensions of the CIMI. Thus, its share of the total is similar to that of other indicators. For example, if a city with a high or relatively high GDP does not have a good performance in other indicators, it may not be in one of the top positions. In this way, a city that is very productive but has problems with transportation, inequality, weak public finance or a production process that uses polluting technology probably will not be in the top positions of the ranking. AdditionaIly, this year we have also included the estimated annual GDP growth to measure the future progress of the city.
For its part, labor productivity allows for a measurement of the strength, efficiency and technological level of the production system, which, with regard to local and international competitiveness, will have repercussions, obviously, on real salaries, capital income, and business profits. For this reason, it is very important to consider the measure in the economic dimension, since different productivity rates can explain differences in the quality of life of a city's workers - and in the sustainability over time of the production system.

The other indicators selected as representative of this dimension enable the measurement of some aspects of the business landscape of a city, such as the number of headquarters of publicly traded parent companies; the entrepreneurial capacity and possibilities of a city's inhabitants, represented by the percentage of entrepreneurs who start their activity motivated by personal improvement; the time required to start a business; and the ease of setting up a business in regulatory terms. These indicators measure a city's sustainability capacity over time and the potential ability to improve the quality of life of its inhabitants. The time required to start a business and the ease of launching it are incorporated into the economic dimension with a negative sign, since lower values indicate a greater ease of starting businesses. The number of headquarters of publicly traded parent companies, the entrepreneurial capacity and possibilities of a city's inhabitants and the number of entrepreneurs have a positive relationship, since the high values of these indicators reflect the economic dynamism of a city and the ease of setting up and starting a new business. 


\section{GOVERNANCE}

Governance is the term commonly used to describe the effectiveness, quality and sound guidance of state intervention. Given that the citizen is the meeting point for solving all the challenges facing cities, factors such as the level of the public's participation, the authorities' ability to involve business leaders and local stakeholders, and the application of e-government plans should be taken into account. Moreover, this dimension encompasses all those actions aimed at improving the administration's efficiency, including the design of new organizational and management models. In this area, great opportunities open up for private initiative, which can bring greater efficiency.

In this work, governance is understood to have a strong correlation with the state of public finances of a city or country. In this sense, public accounts decisively affect people's quality of life and a city's sustainability, since they determine the level of present and future taxes that the residents and the production system must face, the expected growth of the general level of prices, the possibilities of public investment in basic social infrastructure, and incentives for private investment. In addition, if the state has financing needs, it will compete with the private sector for funds available in the financial system, which will affect investment.

The indicators that represent the governance dimension in this report are listed in Table 4, along with their descriptions, units of measurement, and sources of information.

The level of reserves is an indicator of the strength of the public finance system in the short and medium term, of their ability to cope with changing economic cycles, and of the strength and sustainability of the economic structure in relation to the state. Likewise, the number of embassies and consulates is an indicator of the city's international importance for global standards and is based on the embassies that foreign countries assign to the city.

Those cities with certification are committed to improving their services and quality of life. Therefore, a new variable is included this year that takes into account whether or not a city has ISO 37120 certification. The standards for smart cities are established in this standard, which is based on 100 indicators and aims to provide a parameter to compare all cities equally. This variable is incorporated with a positive sign.

The number of research centers and the number of government buildings show the degree of representativeness of local government among the public for attending to their requests and carrying out administrative tasks, regulation, etc. These variables are incorporated with a positive sign in the CIMI calculation.

The strength of legal rights index measures the degree to which collateral and bankruptcy laws protect the rights of borrowers and lenders and thus facilitate access to loans. The values go from 0 (low) to 12 (high) and the highest ratings indicate that the laws are better designed to expand access to credit. Creating the conditions and ensuring the effective implementation of the rights of the public and companies situated in their territory are functions that pertain to national or local governments and cannot be delegated. The perception of the observance of legal rights influences all aspects of life in a country or city, such as its business climate, investment incentives, and legal certainty, among others. For this reason, the strength of rights index has been incorporated with a positive sign in the creation of this dimension.

The government corruption perceptions index is a way to measure the quality of governance, since a high perception in society of corruption in public bodies is a sign that state intervention is not being efficient from the point of view of the social economy, given that public services - understood in a broad sense - involve higher costs in relation to a situation with no corruption. In addition, incentives to invest or settle in countries or cities with a high perception of corruption will be lower than in others with low levels, which negatively affects the sustainability of the country or city. In the case of the $\mathbf{C I M I}$, it is taken as an explanatory indicator of the governance dimension, with a positive sign, due to how the index is calculated by the organization Transparency International, which assigns a value of 0 to countries with a high level of corruption and 100 for those that are very transparent.

Finally, the variable that considers whether a city's government has an open data platform is an indicator of transparency in government management, a communication channel with the public and a platform for generating new business models. The variable assigns a value of 1 if there is an open data platform and 0 otherwise. Therefore, the indicator is incorporated with a positive sign into this dimension.

The E-Government Development Index (EGDI) reflects how a country is using information technology to promote access and inclusion for its people. It is a measure composed of three important dimensions of e-government: the provision of online services, telecommunications connectivity and human capacity. This variable is incorporated with a positive sign. 


\section{TABLE 4. GOVERNANCE INDICATORS}

\begin{tabular}{|c|c|c|c|}
\hline No. & INDICATOR & DESCRIPTION / UNIT OF MEASUREMENT & SOURCE \\
\hline 31 & Reserves & Total reserves in millions of current dollars. & World Bank \\
\hline 32 & Reserves per capita & Reserves per capita in millions of current dollars. & World Bank \\
\hline 33 & Embassies & Number of embassies and consulates per city. & OpenStreetMap \\
\hline 34 & ISO 37120 certification & $\begin{array}{l}\text { This establishes whether or not the city has ISO } 37120 \text { certification. } \\
\text { Certified cities are committed to improving their services and quality of } \\
\text { life. Variable coded from } 0 \text { to } 6 \text {. Cities that have been certified for the } \\
\text { longest time have the highest value. The value } 0 \text { is for cities without } \\
\text { certification. }\end{array}$ & $\begin{array}{l}\text { World Council on City } \\
\text { Data (WCCD) }\end{array}$ \\
\hline 35 & Research centers & Number of research and technology centers per city. & OpenStreetMap \\
\hline 36 & Strength of legal rights & $\begin{array}{l}\text { The strength of legal rights index measures the degree to which collateral } \\
\text { and bankruptcy laws protect the rights of borrowers and lenders and thus } \\
\text { facilitate access to loans. The values go from } 0=\text { low to } 12=\text { high, where } \\
\text { the highest ratings indicate that the laws are better designed to expand } \\
\text { access to credit. }\end{array}$ & World Bank \\
\hline 37 & Corruption perceptions & $\begin{array}{l}\text { Corruption perceptions index. Countries with values close to } 0 \text { are } \\
\text { perceived as very corrupt and those with an index close to } 100 \text { are } \\
\text { perceived as very transparent. }\end{array}$ & $\begin{array}{l}\text { Transparency } \\
\text { International }\end{array}$ \\
\hline 38 & Open data platform & This describes whether the city has an open data system. & $\begin{array}{l}\text { CTIC Foundation and } \\
\text { Open World Bank }\end{array}$ \\
\hline 39 & $\begin{array}{l}\text { E-Government Development } \\
\text { Index }\end{array}$ & $\begin{array}{l}\text { The E-Government Development Index (EGDI) reflects how a country } \\
\text { is using information technology to promote access and inclusion for its } \\
\text { people. }\end{array}$ & United Nations \\
\hline 40 & Democracy & $\begin{array}{l}\text { Ranking where the countries in the highest positions are those considered } \\
\text { more democratic. }\end{array}$ & The Economist \\
\hline 41 & Government buildings & Number of government buildings and premises in the city. & OpenStreetMap \\
\hline
\end{tabular}

Finally, the Democracy Index is considered. This index shows a country's degree of democracy, represented by its electoral system, freedom of expression, functioning of the government, political participation and political culture. It is incorporated with a negative sign since the countries in the highest positions are those considered more democratic.

\section{THE ENVIRONMENT}

Sustainable development of a city can be defined as "development that meets the needs of the present without compromising the ability of future generations to meet their own needs." In this respect, factors such as improving environmental sustainability through antipollution plans, support for green buildings and alternative energy, efficient water management, and the existence of policies that help counter the effects of climate change are essential to guarantee the long-term sustainability of cities.

Since the CIMI also seeks to measure the environmental sustainability of cities, the environment is included as one of the essential aspects of measurement. Table 5

${ }^{1}$ Definition used in 1987 by the UN's World Commission on Environment and Development, created in 1983. sets out the indicators selected in this dimension, as well as brief descriptions, their units of measurement, and the sources of the information.

The indicators selected include measurements of air pollution sources and water quality in cities, which are indicators of the quality of life of their inhabitants, as well as the sustainability of their production or urban matrix.

Carbon dioxide emissions come from the burning of fossil fuels and the manufacture of cement, while methane emissions arise from human activities such as agriculture and the industrial production of methane. $\mathrm{CO}_{2}$ and methane emissions are the main measures that are commonly used to quantify the degree of air pollution, since they are substances that are strongly related to the greenhouse effect. In fact, the decline in these indicators' values is one of targets of the Kyoto Protocol.

Other very important indicators for measuring air pollution in cities are PM2.5 and PM10, a designation that corresponds to small particles, solid or liquid, of dust, ash, soot, metal particles, cement, or pollen, scattered in the atmosphere and whose diameter is less than 2.5 and 10 micrometers $(\mu \mathrm{m})$, respectively. These particles 


\section{TABLE 5. ENVIRONMENTAL INDICATORS}

\begin{tabular}{|c|c|c|c|}
\hline No. & INDICATOR & DESCRIPTION / UNIT OF MEASUREMENT & SOURCE \\
\hline 42 & $\mathrm{CO}_{2}$ emissions & $\begin{array}{l}\text { Carbon dioxide emissions from the burning of fossil fuels and the } \\
\text { manufacture of cement. Measured in kilotons (kt). }\end{array}$ & World Bank \\
\hline 43 & $\mathrm{CO}_{2}$ emission index & $\mathrm{CO}_{2}$ emission index. & Numbeo \\
\hline 44 & Methane emissions & $\begin{array}{l}\text { Methane emissions that arise from human activities such as agriculture } \\
\text { and the industrial production of methane. Measured in } \mathrm{kt} \text { of } \mathrm{CO}_{2} \\
\text { equivalent. }\end{array}$ & World Bank \\
\hline 45 & Access to the water supply & $\begin{array}{l}\text { Percentage of the population with reasonable access to an appropriate } \\
\text { quantity of water resulting from an improvement in the water supply. }\end{array}$ & World Bank \\
\hline 46 & PM2.5 & $\begin{array}{l}\text { PM2.5 measures the number of particles in the air whose diameter is } \\
\text { less than } 2.5 \mu \mathrm{m} \text {. Annual mean. }\end{array}$ & $\begin{array}{l}\text { World Health } \\
\text { Organization }\end{array}$ \\
\hline 47 & PM10 & $\begin{array}{l}\text { PM10 measures the number of particles in the air whose diameter is less } \\
\text { than } 10 \mu \mathrm{m} \text {. Annual mean. }\end{array}$ & $\begin{array}{l}\text { World Health } \\
\text { Organization }\end{array}$ \\
\hline 48 & Pollution & Pollution index. & Numbeo \\
\hline 49 & $\begin{array}{l}\text { Environmental Performance } \\
\text { Index }\end{array}$ & $\begin{array}{l}\text { This measures environmental health and ecosystem vitality. Scale from } 1 \\
\text { (poor) to } 100 \text { (good). }\end{array}$ & Yale University \\
\hline 50 & Renewable water resources & Total renewable water sources per capita. & FAO \\
\hline 51 & Future climate & $\begin{array}{l}\text { Percentage of summer temperature increase in the city forecast for } 2100 \\
\text { if carbon pollution continues to increase. }\end{array}$ & Climate Central \\
\hline 52 & Solid waste & $\begin{array}{l}\text { Average amount of municipal solid waste (garbage) generated annually } \\
\text { per person ( } \mathrm{kg} / \mathrm{yr} \text { ). }\end{array}$ & $\begin{array}{l}\text { Waste Management } \\
\text { for Everyone }\end{array}$ \\
\hline
\end{tabular}

are formed primarily by inorganic compounds such as silicates and aluminates, heavy metals, and organic material associated with carbon particles (soot). These indicators are commonly used in the indexes that seek to measure the state of environmental pollution. They are also complemented by the information provided by a city's pollution index, which estimates its overall pollution. The greatest weight is given to those cities with the highest air pollution.

The Environmental Performance Index (EPI), calculated by Yale University, is an indicator based on the measurement of two major dimensions related to the environment: environmental health and ecosystem vitality. The first is divided into three subdimensions: effects on human health of air pollution, water quality and the environmental burden of diseases. Ecosystem vitality contains seven subdimensions: effects on the ecosystem of air pollution, water quality, biodiversity and habitat, afforestation, fish, agriculture, and climate change. Given the completeness of this indicator - which covers almost all aspects related to measuring the state and evolution of the environment in a city, complemented by the other indicators that the CIMI incorporates - the environment dimension is considered to be represented proportionately.
Water is a renewable energy source that is fundamental for dealing with climate change and its devastating effects. The variable of total renewable water sources per capita considers both internal and external renewable surface water resources. The variable represents the resources that a country has for a sustainable future. For this reason, it is included with a positive sign in the calculation of the index.

This year's edition includes a variable that represents the percentage increase of the city's summer temperature, forecast for 2100 if carbon pollution continues to increase. This variable shows the future risks of today's pollution. This variable is included with a negative sign, since a continuous increase in a city's temperature poses a threat to public health and the economy.

Finally, the average amount of municipal solid waste (garbage) generated annually per person (kg/year) in a city represents potential harm for its inhabitants and the environment due to the prevalence of poor solid waste management. In many cities, this poor management also means an additional health risk for the people who work with this waste. For this reason, the variable is incorporated into the index with a negative sign. 


\section{MOBILITY AND TRANSPORTATION}

The cities of the future have to tackle two major challenges in the field of mobility and transportation: facilitating movement through cities (often large ones) and access to public services.

Mobility and transportation - both with regard to road and route infrastructure, the vehicle fleet, and public transportation, as well as to air transportation - affect the quality of life of a city's inhabitants and can be vital to the sustainability of cities over time. However, perhaps the most important aspect is the externalities that are generated in the production system, both because of the workforce's need to commute and because of the need for an outlet for production.

Table 6 sets out the indicators selected in the dimension of mobility and transportation, descriptions of them, their units of measurement and the sources of information.

The general traffic index, the index of traffic caused by commuting to work, and the inefficiency index are estimates of the traffic inefficiencies caused by long driving times and by the dissatisfaction that these situations generate in the population. These indicators are a measure of the safety of roads and public transportation, which, if it is effective and has a good infrastructure, promotes a decrease in vehicular traffic on the roads and reduces the number of accidents. All these are included with a negative sign in the calculation of the CIMI, since they have a negative impact on the development of a sustainable city.

The bike-sharing indicator collects information about a city's bike-sharing system, which enables moving from one location to another using bicycles available for public use. The indicator varies between 0 and 8 , where 0 refers to the lack of this system in the city and 8 refers to a highly developed system. The variable is incorporated with a positive sign in the CIMI.

The number of metro stations and the length of the system are indicators of commitment to the development of the city and investment with respect to the population size. The number of air routes (arrivals), having a high-speed train and the number of gas stations represent the degree of infrastructure and development of a city. A highly developed city will favor the incorporation of new commercial air routes, as well as the circulation and transit of passengers using different means of transport. These indicators are included with a positive sign in the calculation of the index because of the positive influence they have on the dimension.

\section{URBAN PLANNING}

The urban planning of a city has several subdimensions and is closely related to sustainability. If this is inadequate, it causes a reduction in the public's quality of life

\section{TABLE 6. MOBILITY AND TRANSPORTATION INDICATORS}

\begin{tabular}{|c|c|c|c|}
\hline NO. & INDICATOR & DESCRIPTION / UNIT OF MEASUREMENT & SOURCE \\
\hline 53 & Traffic index & $\begin{array}{l}\text { Consideration of the time spent in traffic, the dissatisfaction this } \\
\text { generates, } \mathrm{CO}_{2} \text { consumption and other inefficiencies of the traffic system. }\end{array}$ & Numbeo \\
\hline 54 & Inefficiency index & Estimation of traffic inefficiencies (such as long journey times). & Numbeo \\
\hline 55 & $\begin{array}{l}\text { Index of traffic for commuting } \\
\text { to work }\end{array}$ & Index of time based on how many minutes it takes to commute to work. & Numbeo \\
\hline 56 & Bike sharing & $\begin{array}{l}\text { The bicycle-sharing system shows the automated services for the public } \\
\text { use of shared bicycles that provide transport from one location to another } \\
\text { within a city. The indicator varies between } 0 \text { and } 8 \text { according to how } \\
\text { developed the system is. }\end{array}$ & $\begin{array}{l}\text { Bike-Sharing World } \\
\text { Map }\end{array}$ \\
\hline 57 & Metro length & Length of the metro system per city. & Metrobits.org \\
\hline 58 & Metro stations & Number of metro stations per city. & Metrobits.org \\
\hline 59 & Flights & Number of arrival flights (air routes) in a city. & OpenFlights \\
\hline 60 & Gas stations & Number of gas stations per city. & OpenStreetMap \\
\hline 61 & High-speed train & Binary variable that shows whether the city has a high-speed train or not. & OpenRailwayMap \\
\hline
\end{tabular}


in the medium term and can also negatively affect investment incentives, since a city with inadequate planning or with no planning at all hinders and increases the costs of logistics and workers' transportation, among other aspects.

To improve the habitability of any territory, it is necessary to take into account the local master plans and the design of green areas and spaces for public use, as well as opting for smart growth. The new urban planning methods should focus on creating compact, well-connected cities with accessible public services.

Depending on the information available, several aspects related to urban plans, the quality of health infrastructure, and housing policies are incorporated as indicators of this dimension. Table 7 sets out the indicators included in this dimension, along with their descriptions, their units of measurement, and the sources of information used.

The bicycle is an effective, fast, economical, healthy, and environmentally friendly means of transportation. Therefore its use has a positive impact on a city's sustainable development as it does not cause pollution or use fuel, among other benefits. Considering this positive effect, the index includes the number of bike-rental or bike-sharing points, based on docking stations where bicycles can be picked up or dropped off. Many cities historically considered to be smart cities have a certain positive correlation with a widespread presence of cycling. As a result, this variable is incorporated with a positive sign.
The quality of health infrastructure refers to the percentage of the population with at least sufficient access to sanitation facilities that help avoid the contact of humans, animals, and insects with excreta. For them to be effective, these facilities must be built correctly and undergo proper maintenance. This indicator has a high correlation with that of urban planning, since it can be shown that inadequate planning inevitably results in health problems in the short and medium term.

In addition, from the urban planning and housing point of view, a city with proper urban planning generally has few or no problems of overcrowding in households, since normally housing policy, in relation to the estimated growth of the urban population, is a determining factor in urban planning. For this reason, within the explanatory indicators of this dimension, the number of occupants of each household was considered with a negative sign.

The number of completed buildings and the percentage of high-rises in a city contribute to the creation of compact and organized cities. These variables are incorporated with a positive sign.

\section{INTERNATIONAL OUTREACH}

Cities that want to progress must secure a privileged place in the world. Maintaining global impact involves improving the city brand and its international recognition through strategic tourism plans, the attracting of foreign investment and representation abroad.

\section{TABLE 7. URBAN PLANNING INDICATORS}

\begin{tabular}{|c|c|c|c|}
\hline NO. & INDICATOR & DESCRIPTION / UNIT OF MEASUREMENT & SOURCE \\
\hline 62 & Bicycles for rent & $\begin{array}{l}\text { Number of bike-rental or bike-sharing points, based on docking stations } \\
\text { where they can be picked up or dropped off. }\end{array}$ & OpenStreetMap \\
\hline 63 & $\begin{array}{l}\text { Percentage of the population } \\
\text { with access to sanitation } \\
\text { facilities }\end{array}$ & $\begin{array}{l}\text { Percentage of the population with at least sufficient access to facilities for } \\
\text { the disposal of excreta that can efficiently avoid the contact of humans, } \\
\text { animals and insects with excreta. }\end{array}$ & World Bank \\
\hline 64 & $\begin{array}{l}\text { Number of people per } \\
\text { household }\end{array}$ & $\begin{array}{l}\text { Number of people per household. Occupancy by household is measured } \\
\text { compared to the average. This makes it possible to estimate if a city has } \\
\text { overoccupied or underoccupied households. }\end{array}$ & Euromonitor \\
\hline 65 & High-rise buildings & $\begin{array}{l}\text { Percentage of buildings that are considered high-rises. A high-rise is a } \\
\text { building of at least } 12 \text { stories or } 35 \text { meters ( } 115 \text { feet) high. }\end{array}$ & $\begin{array}{l}\text { Skyscraper Source } \\
\text { Media }\end{array}$ \\
\hline 66 & Buildings & $\begin{array}{l}\text { The buildings variable is the number of completed buildings in the city. } \\
\text { This includes structures such as high-rises, towers and smaller buildings } \\
\text { but excludes other diverse structures and buildings in different states of } \\
\text { completion (in construction, planned, etc.). }\end{array}$ & $\begin{array}{l}\text { Skyscraper Source } \\
\text { Media }\end{array}$ \\
\hline
\end{tabular}


Cities can have a greater or lesser international outreach even if they are from the same country but this is not independent of the degree of openness nationally. This dimension seeks to reflect these differences and to measure the international outreach of cities.

In this respect, the following indicators have been included: airports, number of passengers by airport, number of hotels in a city, ranking of the most-photographed places in the world according to Sightsmap, and number of meetings and conferences that take place according to data from the International Congress and Convention Association. This last indicator is important for a city's international reputation, taking into account that these events usually take place in cities with international hotels, rooms specially fitted out for such ends, good frequency of international flights, and appropriate security measures. Table 8 summarizes these indicators, along with descriptions of them, their units of measurement, and the source of the information.

All indicators of this dimension, except Sightsmap, are incorporated with a positive sign into the calculation of the CIMI since, faced with higher values of the indicators, the city has a greater impact on the world. Sightsmap is incorporated with a negative sign, since the top positions in the ranking correspond with the most-photographed cities.

\section{TECHNOLOGY}

Although not the only important aspect for cities, information and communications technology (ICT) is part of the backbone of any society that wants to achieve "smart" status.

Technology, an integral dimension of the CIMI, is an aspect of society that improves the present quality of life, and its level of development or spread is an indicator of the quality of life achieved or the potential quality of life. In addition, technological development is a dimension that allows cities to be sustainable over time and to maintain or extend the competitive advantages of their production system and the quality of employment. A technologically backward city has comparative disadvantages with respect to other cities, both from the point of view of security, education, and health, all fundamental to the sustainability of society, and from the point of view of the productive apparatus. As a consequence of this, the production functions become anachronistic. Competitiveness, without protectionism, becomes depleted, which has a negative effect on the city's capacity for consumption and investment, as well as reducing labor productivity.

The indicators selected for measuring the cities' performance in terms of the reach of technology and growth in the cities are set out in Table 9 below.

\section{TABLE 8. INTERNATIONAL OUTREACH INDICATORS}

\begin{tabular}{|c|c|c|c|}
\hline NO. & INDICATOR & DESCRIPTION / UNIT OF MEASUREMENT & SOURCE \\
\hline 67 & McDonald's & Number of McDonald's restaurants per city. & OpenStreetMap \\
\hline 68 & Airports & $\begin{array}{l}\text { Number of points where flight operations take place within a } 40 \mathrm{~km} \\
\text { radius from the latitude and longitude defining the center of the city. } \\
\text { It includes airports, aerodromes, airfields, and landing strips whether } \\
\text { international, private, military or otherwise. Also included are the } \\
\text { buildings used for processing passengers and cargo (terminals). }\end{array}$ & OpenStreetMap \\
\hline 69 & $\begin{array}{l}\text { Number of passengers per } \\
\text { airport }\end{array}$ & Number of passengers per airport in thousands. & Euromonitor \\
\hline 70 & Sightsmap & $\begin{array}{l}\text { Ranking of cities according to the number of photos taken in the city and } \\
\text { uploaded to Panoramio (community for sharing photographs online). The } \\
\text { top positions correspond to the cities with the most photographs. }\end{array}$ & Sightsmap \\
\hline 71 & $\begin{array}{l}\text { Number of conferences and } \\
\text { meetings }\end{array}$ & $\begin{array}{l}\text { Number of international conferences and meetings that take place in a } \\
\text { city. }\end{array}$ & $\begin{array}{l}\text { International Congress } \\
\text { and Convention } \\
\text { Association }\end{array}$ \\
\hline 72 & Hotels & Number of hotels per capita. & OpenStreetMap \\
\hline
\end{tabular}


The indicators that represent the number of Twitter, Facebook and LinkedIn users are grouped into a variable called "social media." The variable is incorporated with a positive sign in the CIMI, since it shows the degree to which a city's inhabitants are connected to the technology.

The variables showing the percentage of households with the Internet, percentage of households with mobile phones, landline subscriptions and broadband subscriptions show the degree of technological development that a city has, facilitating the access of households and businesses to the means necessary to make efficient use of technology.

The Innovation Cities Index (ICl) is calculated by carrying out assessments on the basis of various factors regarding technological innovation in cities, in sectors such as health, the economy in general and the population, among others. It is now the most comprehensive indicator for measuring the degree of development of innovation in cities, and is divided methodologically into three aspects or dimensions: cultural assets, human infrastructure and interconnected markets.
The number of wireless access points globally represents the connection options available to the city's inhabitants when they are outside their home. This variable represents the city's degree of commitment to technological development.

Finally, the number of Apple Stores that a city has represents its inhabitants' demand for technology. A high number of stores in a city is due to a greater need among the population to have the latest generation of technological means.

All the indicators of this dimension are related directly to technology, so they are incorporated with a positive sign in this dimension.

\section{TABLE 9. TECHNOLOGY INDICATORS}

\begin{tabular}{|c|c|c|c|}
\hline No. & INDICATOR & DESCRIPTION / UNIT OF MEASUREMENT & SOURCE \\
\hline 73 & Twitter & $\begin{array}{l}\text { Registered Twitter users in the city. This is part of the "social media" } \\
\text { variable. }\end{array}$ & Tweet Map \\
\hline 74 & Linkedln & $\begin{array}{l}\text { Number of registered users in the city. This is part of the "social media" } \\
\text { variable. }\end{array}$ & Linkedln \\
\hline 75 & Facebook & $\begin{array}{l}\text { Number of people who are currently registered in the city. Facebook is } \\
\text { part of the "social media" variable. }\end{array}$ & Facebook \\
\hline 76 & Mobile phones & $\begin{array}{l}\text { Number of mobile phones in the city, using estimates in line with } \\
\text { country-level data. }\end{array}$ & $\begin{array}{l}\text { International } \\
\text { Telecommunication } \\
\text { Union }\end{array}$ \\
\hline 77 & Wi-Fi hot spot & $\begin{array}{l}\text { Number of wireless access points globally. These represent the options } \\
\text { there are in the city for connecting to the Internet. }\end{array}$ & Wi-Fi Map app \\
\hline 78 & Apple Store & Number of Apple Stores per city. & OpenStreetMap \\
\hline 79 & Innovation index & $\begin{array}{l}\text { The city's innovation index. Valuation from } 0=\text { no innovation to } 60=\text { a lot } \\
\text { of innovation. }\end{array}$ & $\begin{array}{l}\text { Innovation Cities } \\
\text { Program }\end{array}$ \\
\hline 80 & Landline subscriptions & Number of landline subscriptions per 100 inhabitants. & $\begin{array}{l}\text { International } \\
\text { Telecommunication } \\
\text { Union }\end{array}$ \\
\hline 81 & Broadband subscriptions & Broadband subscriptions per 100 inhabitants. & $\begin{array}{l}\text { International } \\
\text { Telecommunication } \\
\text { Union }\end{array}$ \\
\hline 82 & Internet & Percentage of households with access to the Internet. & Euromonitor \\
\hline 83 & Mobile telephony & Percentage of households with mobile phones in the city. & Euromonitor \\
\hline
\end{tabular}




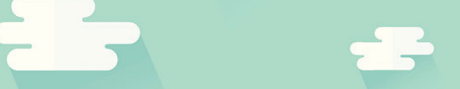

\section{LIMITATIONS OF THE INDICATORS}

Appendix 1 describes, by way of summary, all the indicators used in each of the dimensions and includes brief descriptions, units of measurement and the sources of information.

Perhaps the most significant limitation in the calculation of the $\mathbf{C I M I}$ is linked to the availability of data. Nevertheless, efforts were made to minimize this impact. First of all, for those indicators that did not have data for the entire period under analysis, extrapolation techniques were used. For situations where the indicator values by city were nonexistent but where there were valid values by country, individual values were assigned to each city, connecting the indicator at the country level via some other variable linked theoretically at the city level. Lastly, there were cases where no data were available for a particular city or group of cities for the whole period under consideration. In this case, statistical cluster techniques were used. The scope and detail of these tools are discussed in detail in the supplementary document "Methodology and Modeling" from 2014.

With the CIMI platform, we continue to work to obtain more complete and accurate indicators, while we urge cities to allow access to the information they generate.

\section{GEOGRAPHIC COVERAGE}

For the calculation of this year's CIMI, 165 cities have been included, 74 of which are capitals, with the geographical distribution depicted in Figure 1. 


\section{FIGURE 1. GEOGRAPHICAL DISTRIBUTION OF THE CITIES INCLUDED IN THE INDEX}

\section{Western Europe}

Linz, Austria

Vienna, Austria

Antwerp, Belgium
Brussels, Belgium

Brussels, Belgium
Copenhagen, Denmark
Helsinki, Finland

Lille, France

Lyon, France

Marseille, France

Nice, France
Paris, France

Berlin, Germany

Cologne, Germany

Duisburg, Germany

Hamburg, Germany
Munich, Germany
Stuttgart, Germany
Athens, Greece
Reykjavik, Iceland
Dublin, Ireland
Florence, Italy
Milan, Italy
Naples, Italy
Rome, Italy
Turin, Italy
Amsterdam, Netherlands
Eindhoven, Netherlands
Rotterdam, Netherlands
Oslo, Norway

Lisbon, Portugat

A Coruña, Spain

Barcelona, Spain

Bilbao, Spain
Madrid, Spain

Málaga, Spain

Murcia, Spain

Palma de Mallorca, Spain

Seville, Spain

Valencia, Spain
Valladolid, Spain

Valladolid, Spain
Vigo, Spain

Zaragoza, Spain

Göteborg, Sweden
Stockholm, Sweden

Basel, Switzerland

Gern, Switzerland

Geneva, Switzerland

Birmingham, United Kingdom

Glasgow, United Kingdom

Leeds, United Kingdom

Liverpool, United Kingdom

London, United Kingdom

Manchester, United Kingdom

Nottingham, United Kingdom

\section{Eastern Europe and Russia}

Baku, Azerbaija
Minsk, Belarus

Sofia, Bulgaria and Herzegovina

Zagreb, Croatia

Prague, Czech Republic

Tallinn, Estonia

Tbilisi, Georgia

Budapest, Hunge

Riga, Latvia
Vilnius, Lithuania

Moscow, Russia
Novosibirsk, Russi

Saint Petersburg, Russia

Belgrade, Serbia

Bratislava, Slovakia

Ljubljana, Slovenia
Ankara, Turkey

Istanbul Turkey

Kiev, Ukraine

\section{Asia}

Beijing, China

Guangzhou, China

Hong Kong, China

Shanghai, China
Shenzhen, China

Tianijin, China

Kolkata, India

Mumbai, India

New Delhi, India

Nagoya, Japan

Osaka, Japan

Tokyo, Japan

Kuala Lumpur, Malaysia

Karachi, Pakistan

Singapore, Singa pore

Seoul, South Korea

Bangkok, Thailand

Manama, Bahrain Jerusalem, Israel
Tel Aviv, Israel

\section{Africa}

Douala, Cameroon Cairo, Egypt

Nairobi, Kenya

Casablanca, Morocco

Rabat, Morocco
Lagos, Nigeria

Lagos, Nigeria
Cape Town, South Africa

Johannesburg, South Africa

Tunis, Tunisia
Amman, Jordan

Kuwait City, Kuwait

Doha, Qatar

Riyadh, Saudi Arabi

Abu Dhabi, UAE

Montevideo, Uruguay

Caracas, Venezuela
Bogota, Colombia
San José, Costa Rica

Guayaquil, Ecuaa
Quito, Ecuador

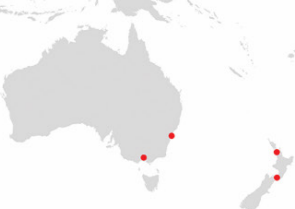

Oceania

Melbourne, Australia

Sydney, Australia

Auckland, New Zealand 


\section{CITIES IN MOTION. RANKING}

The CIMI, which is the subject of this report, is a synthetic indicator and, as such, is a function based on the partial indicators available.

The process of creating this synthetic indicator is based on a model of weighted aggregation of partial indicators that represent each of the nine dimensions that make up the CIMI theoretical model. The dimensions selected to describe the situation of cities in terms of sustainability and the quality of life of their inhabitants, both in the present and in the future, are as follows: governance, urban planning, technology, the environment, international outreach, social cohesion, human capital, mobility and transportation, and the economy.

The partial indicators representative of each dimension also correspond to the category of synthetic indicators, which are defined as "weighted aggregations of each of the selected indicators that represent different factors of each dimension."

Given the type of indicator in question and the data available, for the calculation of the CIMI, the DP2 technique has been used, this being the most widely used internationally and the most suitable. Its methodology is based on distance - that is, the difference between an indicator's given value and another value taken as a reference or target. Likewise, this technique attempts to correct the dependence among the partial indicators, which would artificially increase the indicator's sensitivity to variations in certain partial values. The correction consists of applying the same factor to each partial indicator, assuming a linearly dependent function is established between them. ${ }^{2}$
Given the partial indicators, the factors are given by the complement of the coefficient of determination $\left(R^{2}\right)$ for each indicator compared with the rest of the partial indicators. The order in which the indicators of each dimension have been included, as well as their relative weight in the CIMI, is as follows: the economy (1), human capital (0.521), international outreach (0.564), urban planning (0.538), the environment (0.859), technology (0.394), governance (0.444), social cohesion (0.571) and mobility and transportation (0.516).

While the order in which each synthetic index of each dimension is incorporated influences the value of the CIMI, the sensitivity studies carried out concluded that there are no significant variations in it. More details on the methodology can be seen in the supplementary document "Methodology and Modeling" published in 2014.

Table 10 sets out the CIMI city ranking, together with the index value. The cities are grouped according to their performance, measured by the value of the synthetic indicator. Cities with a high performance $(\mathrm{H})$ are considered to be those with an index greater than 90; relatively high $(\mathrm{RH})$, between 60 and 90 ; average $(\mathrm{A})$, between 45 and 60; and low (L), below 45.

For 2017 , it can be observed that $27.27 \%$ of the cities (45) have a performance rated high $(\mathrm{H})$ or relatively high (RH), headed by New York City, London and Paris. There are 68 cities $(41.21 \%)$ with an average (A) performance, while the performances classified as low (L) include $31.52 \%$ of the selected cities. None of them has a rating of very low. Of the top 25, 12 are in Europe, six in North America, four in Asia, and three in Oceania.

\footnotetext{
${ }^{2}$ Because linear estimates are involved, variables with a normal distribution are required, so a log transformation has been applied to some variables to obtain the said normality. Likewise, outlier techniques have been applied to avoid bias and overestimations of coefficients.
} 
TABLE 10. CITY RANKING

\begin{tabular}{|c|c|c|c|c|c|c|c|}
\hline RANKING & CITY & PERFORMANCE & CIMI & RANKING & CITY & PERFORMANCE & CIMI \\
\hline 1 & New York-United States & A & 100.00 & 62 & San Antonio-United States & $M$ & 56.50 \\
\hline 2 & London-United Kingdom & A & 99.27 & 63 & Valencia-Spain & M & 56.41 \\
\hline 3 & Paris-France & A & 90.20 & 64 & Warsaw-Poland & M & 56.33 \\
\hline 4 & Tokyo-Japan & RA & 84.38 & 65 & Eindhoven-The Netherlands & M & 56.30 \\
\hline 5 & Reykjavik-Iceland & RA & 83.26 & 66 & Rome-Italy & M & 56.23 \\
\hline 6 & Singapore-Singapore & RA & 79.52 & 67 & Bratislava-Slovakia & M & 56.18 \\
\hline 7 & Seoul-South Korea & RA & 79.21 & 68 & Glasgow-United Kingdom & M & 55.87 \\
\hline 8 & Toronto-Canada & RA & 78.16 & 69 & Antwerp-Belgium & M & 55.77 \\
\hline 9 & Hong Kong-China & RA & 77.48 & 70 & Moscow-Russia & M & 55.50 \\
\hline 10 & Amsterdam-The Netherlands & RA & 77.44 & 71 & Nagoya-Japan & M & 55.29 \\
\hline 11 & Berlin-Germany & RA & 76.34 & 72 & Tel Aviv-Israel & M & 55.25 \\
\hline 12 & Melbourne-Australia & RA & 74.91 & 73 & Linz-Austria & M & 54.85 \\
\hline 13 & Copenhagen-Denmark & RA & 74.55 & 74 & Ljubljana-Slovenia & M & 54.72 \\
\hline 14 & Chicago-United States & RA & 73.55 & 75 & Phoenix-United States & M & 54.72 \\
\hline 15 & Sydney-Australia & RA & 73.50 & 76 & Buenos Aires-Argentina & M & 54.68 \\
\hline 16 & Stockholm-Sweden & RA & 73.29 & 77 & Baltimore-United States & M & 54.50 \\
\hline 17 & Los Angeles-United States & RA & 72.80 & 78 & Beijing-China & M & 54.20 \\
\hline 18 & Wellington-New Zealand & RA & 71.64 & 79 & Nice-France & M & 54.15 \\
\hline 19 & Vienna-Austria & RA & 71.51 & 80 & Marseille-France & M & 53.47 \\
\hline 20 & Washington-United States & RA & 70.31 & 81 & Leeds-United Kingdom & M & 53.10 \\
\hline 21 & Boston-United States & RA & 69.39 & 82 & Liverpool-United Kingdom & M & 53.06 \\
\hline 22 & Helsinki-Finland & RA & 69.17 & 83 & Zagreb-Croatia & M & 52.31 \\
\hline 23 & Oslo-Norway & RA & 68.14 & 84 & Lille-France & M & 52.09 \\
\hline 24 & Zurich-Switzerland & RA & 68.04 & 85 & Seville-Spain & M & 51.96 \\
\hline 25 & Madrid-Spain & RA & 67.76 & 86 & Santiago-Chile & M & 51.45 \\
\hline 26 & Barcelona-Spain & RA & 67.53 & 87 & Kuala Lumpur-Malaysia & M & 51.38 \\
\hline 27 & San Francisco-United States & RA & 67.31 & 88 & Porto-Portugal & M & 51.32 \\
\hline 28 & Auckland-New Zealand & RA & 66.33 & 89 & Málaga-Spain & M & 50.44 \\
\hline 29 & Bern-Switzerland & RA & 66.12 & 90 & Bangkok-Thailand & M & 50.34 \\
\hline 30 & Dublin-Ireland & RA & 65.63 & 91 & Duisburg-Germany & M & 50.19 \\
\hline 31 & Hamburg-Germany & RA & 65.10 & 92 & Palma de Mallorca-Spain & M & 49.96 \\
\hline 32 & Geneva-Switzerland & RA & 64.96 & 93 & Zaragoza-Spain & M & 49.82 \\
\hline 33 & Göteborg-Sweden & RA & 64.95 & 94 & Panama City-Panama & M & 49.77 \\
\hline 34 & Basel-Switzerland & RA & 64.88 & 95 & Murcia-Spain & M & 49.76 \\
\hline 35 & Ottawa-Canada & RA & 64.79 & 96 & Nottingham-United Kingdom & M & 49.26 \\
\hline 36 & Vancouver-Canada & RA & 64.78 & 97 & Abu Dhabi-United Arab Emirates & M & 49.22 \\
\hline 37 & Munich-Germany & RA & 64.42 & 98 & Florence-Italy & M & 48.88 \\
\hline 38 & Montreal-Canada & RA & 64.42 & 99 & Valladolid-Spain & M & 48.57 \\
\hline 39 & Houston-United States & RA & 64.36 & 100 & Montevideo-Uruguay & M & 48.25 \\
\hline 40 & Prague-Czech Republic & RA & 63.85 & 101 & Sofia-Bulgaria & M & 48.10 \\
\hline 41 & Dallas-United States & RA & 61.70 & 102 & San José-Costa Rica & M & 48.08 \\
\hline 42 & Frankfurt-Germany & RA & 61.61 & 103 & Bilbao-Spain & M & 47.97 \\
\hline 43 & Rotterdam-The Netherlands & RA & 60.62 & 104 & Vigo-Spain & M & 47.82 \\
\hline 44 & Lyon-France & RA & 60.49 & 105 & A Coruña-Spain & M & 46.45 \\
\hline 45 & Milan-Italy & RA & 60.06 & 106 & Turin-Italy & M & 46.39 \\
\hline 46 & Philadelphia-United States & M & 59.70 & 107 & Mexico City-Mexico & M & 46.35 \\
\hline 47 & San Diego-United States & M & 59.34 & 108 & Minsk-Belarus & M & 46.16 \\
\hline 48 & Brussels-Belgium & M & 59.01 & 109 & Guangzhou-China & M & 45.78 \\
\hline 49 & Riga-Latvia & M & 58.98 & 110 & Belgrade-Serbia & M & 45.73 \\
\hline 50 & Tallinn-Estonia & M & 58.97 & 111 & Doha-Qatar & M & 45.69 \\
\hline 51 & Miami-United States & M & 58.72 & 112 & Tbilisi-Georgia & M & 45.69 \\
\hline 52 & Lisbon-Portugal & M & 58.61 & 113 & Kiev-Ukraine & M & 45.22 \\
\hline 53 & Budapest-Hungary & M & 58.55 & 114 & Istanbul-Turkey & B & 44.98 \\
\hline 54 & Cologne-Germany & M & 58.37 & 115 & Shenzhen-China & B & 44.84 \\
\hline 55 & Stuttgart-Germany & M & 57.94 & 116 & São Paulo-Brazil & B & 44.63 \\
\hline 56 & Osaka-Japan & M & 57.43 & 117 & Bogota-Colombia & B & 44.10 \\
\hline 57 & Shanghai-China & M & 57.33 & 118 & Almaty-Kazakhstan & B & 43.73 \\
\hline 58 & Birmingham-United Kingdom & M & 56.95 & 119 & Naples-Italy & B & 43.59 \\
\hline 59 & Manchester-United Kingdom & $M$ & 56.76 & 120 & Ankara-Turkey & B & 43.57 \\
\hline 60 & Dubai-United Arab Emirates & M & 56.70 & 121 & Jerusalem-Israel & B & 43.14 \\
\hline 61 & Vilnius-Lithuania & M & 56.57 & 122 & Athens-Greece & B & 42.55 \\
\hline
\end{tabular}




\begin{tabular}{|c|c|c|c|}
\hline RANKING & CITY & PERFORMANCE & CIMI \\
\hline 123 & Saint Petersburg-Russia & B & 42.37 \\
\hline 124 & Ho Chi Minh City-Vietnam & B & 42.08 \\
\hline 125 & Skopje-Macedonia & B & 42.04 \\
\hline 126 & Rio de Janeiro-Brazil & B & 41.89 \\
\hline 127 & Baku-Azerbaijan & B & 40.92 \\
\hline 128 & Kuwait City-Kuwait & B & 39.85 \\
\hline 129 & Medellín-Colombia & B & 39.53 \\
\hline 130 & Rosario-Argentina & B & 38.80 \\
\hline 131 & Lima-Peru & B & 38.68 \\
\hline 132 & Sarajevo-Bosnia and Herzegovina & B & 38.60 \\
\hline 133 & Cordoba-Argentina & B & 37.59 \\
\hline 134 & Tunis-Tunisia & B & 37.29 \\
\hline 135 & Curitiba-Brazil & B & 37.09 \\
\hline 136 & Jakarta-Indonesia & B & 36.56 \\
\hline 137 & Cali-Colombia & B & 36.08 \\
\hline 138 & Brasilia-Brazil & B & 36.05 \\
\hline 139 & Amman-Jordan & B & 35.69 \\
\hline 140 & Quito-Ecuador & B & 35.57 \\
\hline 141 & Guatemala City-Guatemala & $\mathrm{B}$ & 35.23 \\
\hline 142 & Novosibirsk-Russia & $\mathrm{B}$ & 34.48 \\
\hline 143 & Cape Town-South Africa & B & 34.30 \\
\hline 144 & Manama-Bahrain & B & 33.30 \\
\hline
\end{tabular}

\section{CITIES IN MOTION. RANKING BY DIMENSION}

This section sets out the ranking according to each of the dimensions that make up the index, together with the city's position overall and for each dimension. To make the visual layout more intuitive, the darker greens correspond to the highest positions in the CIMI ranking, and the darker reds represent the worst-positioned cities. The intermediate positions appear highlighted in yellow shades.

New York City (United States) is in first place in the overall ranking, thanks to its performance in the dimensions of the economy (position 1), urban planning (position 1), international outreach (position 3), human capital (position 4), and mobility and transportation (position 4). However, it continues to be in very low positions in the dimensions of social cohesion (position 109) and the environment (position 99).

London (United Kingdom) is in second place in the overall ranking, thanks to its performance in the dimensions of human capital (position 1), international outreach (position 2), mobility and transportation (position 2), and the economy (position 4). It performs worse in social cohesion (position 68) and the environment (position 40).

\begin{tabular}{|c|l|c|c|}
\hline \multicolumn{1}{|c|}{ RANKITY } & \multicolumn{2}{c|}{ PERFORMANGE } & \multicolumn{1}{c|}{ CIMI } \\
\hline 145 & Santa Cruz-Bolivia & B & 32.97 \\
146 & Manila-Philippines & B & 32.73 \\
147 & Salvador-Brazil & B & 31.65 \\
148 & Casablanca-Morocco & B & 31.26 \\
149 & Tianjin-China & B & 30.61 \\
150 & Guayaquil-Ecuador & B & 30.35 \\
151 & Belo Horizonte-Brazil & B & 30.21 \\
152 & La Paz-Bolivia & B & 30.08 \\
153 & Riyadh-Saudi Arabia & B & 29.13 \\
154 & Santo Domingo-Dominican Republic & B & 29.10 \\
155 & Rabat-Morocco & B & 28.12 \\
156 & Johannesburg-South Africa & B & 27.42 \\
157 & Cairo-Egypt & B & 27.24 \\
158 & Mumbai-India & B & 26.67 \\
159 & New Delhi-India & B & 26.60 \\
160 & Douala-Cameroon & B & 26.52 \\
161 & Nairobi-Kenya & B & 25.97 \\
162 & Caracas-Venezuela & B & 21.38 \\
163 & Kolkata-India & B & 21.14 \\
164 & Lagos-Nigeria & B & 20.41 \\
165 & Karachi-Pakistan & B & 17.23 \\
\hline
\end{tabular}

The city of Reykjavik (Iceland), added to the CIMI this year, stands out in position 5 of the overall ranking, occupying first place in the environment dimension. It also stands out in mobility and transportation and in technology, in position 7 in both dimensions. However, it performs poorly in the international outreach dimension, where it occupies position 121.

Of the top 30 positions in the overall ranking, half are occupied by European cities. Additionally, of the 14 U.S. cities considered in the $\mathbf{C I M I}$, six are in the top 30 of the overall ranking.

Table 11 shows both the overall ranking and the ranking by dimension for the 165 cities included in the CIMI. The interpretation of the table is very important for the analysis of the results, since the relative position of all cities in each of the dimensions can be observed. In Figure 2, the positions of the cities on the world map can be seen. In addition, the data for each city can be accessed at the official webpage of IESE Cities in Motion with an interactive interface that also allows the user to compare two cities at once. 


\section{$\overline{\text { TABLE 11. RANKING BY DIMENSION }}$}

\begin{tabular}{|c|c|c|c|c|c|c|c|c|c|c|}
\hline City & Economy & $\begin{array}{l}\text { Human } \\
\text { Capital }\end{array}$ & $\begin{array}{l}\text { Social } \\
\text { Cohesion }\end{array}$ & Environment & Governance & $\begin{array}{l}\text { Urban } \\
\text { Planning }\end{array}$ & $\begin{array}{l}\text { International } \\
\text { Outreach }\end{array}$ & Technology & $\begin{array}{l}\text { Mobility and } \\
\text { Transportation }\end{array}$ & $\begin{array}{l}\text { Cities in } \\
\text { Motion }\end{array}$ \\
\hline New York-United States & 1 & 4 & 109 & 99 & 38 & 1 & 3 & 5 & 4 & 1 \\
\hline London-United Kingdom & 4 & 1 & 68 & 40 & 5 & 7 & 2 & 6 & 2 & 2 \\
\hline Paris-France & 7 & 8 & 87 & 49 & 43 & 3 & 1 & 12 & 1 & 3 \\
\hline Tokyo-Japan & 2 & 5 & 48 & 11 & 40 & 32 & 17 & 27 & 22 & 4 \\
\hline Reykjavik-Iceland & 27 & 83 & 47 & 1 & 27 & 66 & 121 & 7 & 7 & 5 \\
\hline Singapore-Singapore & 13 & 39 & 90 & 10 & 8 & 39 & 5 & 2 & 63 & 6 \\
\hline Seoul-South Korea & 15 & 11 & 38 & 25 & 22 & 40 & 20 & 10 & 3 & 7 \\
\hline Toronto-Canada & 28 & 24 & 28 & 55 & 4 & 2 & 25 & 16 & 68 & 8 \\
\hline Hong Kong-China & 19 & 12 & 147 & 21 & 16 & 10 & 16 & 1 & 87 & 9 \\
\hline Amsterdam-Netherlands & 36 & 46 & 26 & 36 & 23 & 13 & 6 & 3 & 13 & 10 \\
\hline Berlin-Germany & 66 & 7 & 3 & 54 & 14 & 49 & 4 & 33 & 6 & 11 \\
\hline Melbourne-Australia & 34 & 18 & 8 & 26 & 2 & 19 & 10 & 48 & 38 & 12 \\
\hline Copenhagen-Denmark & 12 & 54 & 23 & 3 & 13 & 90 & 32 & 20 & 43 & 13 \\
\hline Chicago-United States & 10 & 10 & 96 & 127 & 46 & 5 & 9 & 28 & 42 & 14 \\
\hline Sydney-Australia & 35 & 15 & 20 & 22 & 26 & 17 & 21 & 8 & 76 & 15 \\
\hline Stockholm-Sweden & 5 & 55 & 64 & 8 & 19 & 45 & 36 & 25 & 44 & 16 \\
\hline Los Angeles-United States & 3 & 2 & 79 & 144 & 7 & 23 & 11 & 38 & 112 & 17 \\
\hline Wellington-New Zealand & 22 & 85 & 15 & 2 & 25 & 14 & 132 & 62 & 15 & 18 \\
\hline Vienna-Austria & 72 & 31 & 36 & 18 & 18 & 41 & 8 & 23 & 14 & 19 \\
\hline Washington-United States & 11 & 6 & 72 & 128 & 21 & 12 & 49 & 32 & 41 & 20 \\
\hline Boston-United States & 14 & 3 & 61 & 118 & 12 & 30 & 55 & 39 & 77 & 21 \\
\hline Helsinki-Finland & 32 & 57 & 1 & 12 & 6 & 61 & 50 & 55 & 67 & 22 \\
\hline Oslo-Norway & 17 & 62 & 21 & 13 & 51 & 48 & 64 & 24 & 78 & 23 \\
\hline Zurich-Switzerland & 24 & 40 & 4 & 24 & 9 & 97 & 62 & 31 & 75 & 24 \\
\hline Madrid-Spain & 64 & 34 & 53 & 50 & 34 & 37 & 19 & 21 & 9 & 25 \\
\hline Barcelona-Spain & 78 & 37 & 86 & 66 & 15 & 16 & 14 & 15 & 12 & 26 \\
\hline San Francisco-United States & 6 & 13 & 75 & 110 & 70 & 28 & 41 & 14 & 98 & 27 \\
\hline Auckland-New Zealand & 18 & 87 & 27 & 14 & 52 & 27 & 70 & 65 & 69 & 28 \\
\hline Bern-Switzerland & 47 & 72 & 2 & 73 & 1 & 108 & 131 & 107 & 31 & 29 \\
\hline Dublin-Ireland & 16 & 80 & 22 & 35 & 45 & 75 & 44 & 17 & 100 & 30 \\
\hline Hamburg-Germany & 57 & 27 & 33 & 67 & 31 & 44 & 48 & 53 & 11 & 31 \\
\hline Geneva-Switzerland & 31 & 70 & 25 & 68 & 3 & 93 & 80 & 13 & 54 & 32 \\
\hline Göteborg-Sweden & 21 & 64 & 62 & 19 & 32 & 76 & 104 & 73 & 20 & 33 \\
\hline
\end{tabular}




\section{TABLE 11. RANKING BY DIMENSION (CONTINUED)}

\begin{tabular}{|c|c|c|c|c|c|c|c|c|c|c|}
\hline City & Economy & $\begin{array}{l}\text { Human } \\
\text { Capital }\end{array}$ & $\begin{array}{l}\text { Social } \\
\text { Cohesion }\end{array}$ & Environment & Governance & $\begin{array}{c}\text { Urban } \\
\text { Planning }\end{array}$ & $\begin{array}{c}\text { International } \\
\text { Outreach }\end{array}$ & Technology & $\begin{array}{l}\text { Mobility and } \\
\text { Transportation }\end{array}$ & $\begin{array}{l}\text { Cities in } \\
\text { Motion }\end{array}$ \\
\hline Basel-Switzerland & 44 & 59 & 5 & 41 & 11 & 100 & 58 & 70 & 18 & 34 \\
\hline Ottawa-Canada & 52 & 38 & 14 & 59 & 10 & 8 & 109 & 78 & 71 & 35 \\
\hline Vancouver-Canada & 42 & 45 & 37 & 78 & 35 & 4 & 43 & 44 & 105 & 36 \\
\hline Munich-Germany & 38 & 42 & 9 & 72 & 67 & 72 & 42 & 69 & 8 & 37 \\
\hline Montreal-Canada & 51 & 51 & 39 & 63 & 24 & 9 & 23 & 118 & 80 & 38 \\
\hline Houston-United States & 8 & 17 & 59 & 146 & 44 & 25 & 29 & 29 & 107 & 39 \\
\hline Prague-Czech Republic & 82 & 61 & 31 & 23 & 60 & 94 & 27 & 18 & 66 & 40 \\
\hline Dallas-United States & 9 & 19 & 81 & 134 & 57 & 55 & 45 & 66 & 104 & 41 \\
\hline Frankfurt-Germany & 45 & 32 & 67 & 93 & 81 & 29 & 34 & 94 & 29 & 42 \\
\hline Rotterdam-Netherlands & 75 & 58 & 18 & 56 & 82 & 11 & 92 & 61 & 21 & 43 \\
\hline Lyon-France & 43 & 60 & 45 & 52 & 63 & 38 & 67 & 101 & 36 & 44 \\
\hline Milan-Italy & 69 & 35 & 92 & 57 & 104 & 47 & 46 & 71 & 16 & 45 \\
\hline Philadelphia-United States & 20 & 14 & 93 & 143 & 62 & 42 & 59 & 63 & 85 & 46 \\
\hline San Diego-United States & 25 & 23 & 80 & 136 & 17 & 53 & 73 & 19 & 113 & 47 \\
\hline Brussels-Belgium & 65 & 95 & 69 & 47 & 71 & 59 & 53 & 45 & 19 & 48 \\
\hline Riga-Latvia & 84 & 78 & 78 & 5 & 72 & 24 & 106 & 49 & 47 & 49 \\
\hline Tallinn-Estonia & 83 & 84 & 54 & 4 & 96 & 26 & 126 & 30 & 59 & 50 \\
\hline Miami-United States & 29 & 20 & 107 & 132 & 89 & 46 & 22 & 46 & 90 & 51 \\
\hline Lisbon-Portugal & 88 & 66 & 77 & 9 & 74 & 95 & 33 & 41 & 93 & 52 \\
\hline Budapest-Hungary & 110 & 52 & 101 & 17 & 64 & 70 & 35 & 34 & 65 & 53 \\
\hline Cologne-Germany & 67 & 47 & 19 & 98 & 37 & 118 & 54 & 60 & 55 & 54 \\
\hline Stuttgart-Germany & 49 & 53 & 13 & 64 & 68 & 113 & 79 & 116 & 45 & 55 \\
\hline Osaka-Japan & 41 & 49 & 60 & 30 & 83 & 104 & 74 & 96 & 84 & 56 \\
\hline Shanghai-China & 60 & 16 & 148 & 149 & 30 & 56 & 26 & 52 & 5 & 57 \\
\hline Birmingham-United Kingdom & 53 & 22 & 29 & 74 & 41 & 63 & 98 & 90 & 116 & 58 \\
\hline Manchester-United Kingdom & 56 & 21 & 30 & 104 & 58 & 82 & 65 & 75 & 108 & 59 \\
\hline Dubai-United Arab Emirates & 54 & 130 & 44 & 151 & 33 & 112 & 13 & 4 & 102 & 60 \\
\hline Vilnius-Lithuania & 91 & 68 & 98 & 16 & 39 & 52 & 114 & 84 & 40 & 61 \\
\hline San Antonio-United States & 23 & 26 & 84 & 133 & 97 & 57 & 101 & 42 & 79 & 62 \\
\hline Valencia-Spain & 98 & 97 & 50 & 43 & 20 & 60 & 112 & 74 & 25 & 63 \\
\hline Warsaw-Poland & 108 & 65 & 58 & 83 & 50 & 15 & 30 & 114 & 58 & 64 \\
\hline Eindhoven-Netherlands & 58 & 73 & 7 & 113 & 49 & 21 & 162 & 51 & 60 & 65 \\
\hline Rome-Italy & 76 & 50 & 120 & 107 & 69 & 129 & 15 & 50 & 23 & 66 \\
\hline
\end{tabular}




\section{TABLE 11. RANKING BY DIMENSION (CONTINUED)}

\begin{tabular}{|c|c|c|c|c|c|c|c|c|c|c|}
\hline City & Economy & $\begin{array}{l}\text { Human } \\
\text { Capital }\end{array}$ & $\begin{array}{l}\text { Social } \\
\text { Cohesion }\end{array}$ & Environment & Governance & $\begin{array}{l}\text { Urban } \\
\text { Planning }\end{array}$ & $\begin{array}{c}\text { International } \\
\text { Outreach }\end{array}$ & Technology & $\begin{array}{l}\text { Mobility and } \\
\text { Transportation }\end{array}$ & $\begin{array}{l}\text { Cities in } \\
\text { Motion }\end{array}$ \\
\hline Bratislava-Slovakia & 74 & 81 & 16 & 32 & 42 & 64 & 90 & 131 & 91 & 67 \\
\hline Glasgow-United Kingdom & 59 & 36 & 35 & 75 & 56 & 91 & 69 & 67 & 119 & 68 \\
\hline Antwerp-Belgium & 80 & 99 & 32 & 45 & 117 & 33 & 123 & 85 & 17 & 69 \\
\hline Moscow-Russia & 105 & 9 & 146 & 101 & 36 & 22 & 51 & 80 & 70 & 70 \\
\hline Nagoya-Japan & 46 & 56 & 40 & 20 & 73 & 102 & 133 & 109 & 118 & 71 \\
\hline Tel Aviv-Israel & 48 & 116 & 76 & 38 & 79 & 31 & 103 & 37 & 110 & 72 \\
\hline Linz-Austria & 73 & 76 & 6 & 37 & 75 & 107 & 157 & 98 & 46 & 73 \\
\hline Ljubljana-Slovenia & 89 & 96 & 17 & 34 & 111 & 73 & 111 & 43 & 56 & 74 \\
\hline Phoenix-United States & 37 & 33 & 70 & 138 & 94 & 65 & 115 & 92 & 37 & 75 \\
\hline Buenos Aires-Argentina & 151 & 43 & 94 & 33 & 29 & 18 & 24 & 126 & 96 & 76 \\
\hline Baltimore-United States & 33 & 28 & 97 & 139 & 47 & 51 & 105 & 86 & 99 & 77 \\
\hline Beijing-China & 50 & 29 & 129 & 160 & 76 & 111 & 12 & 57 & 10 & 78 \\
\hline Nice-France & 71 & 63 & 55 & 69 & 90 & 85 & 87 & 81 & 82 & 79 \\
\hline Marseille-France & 63 & 82 & 88 & 87 & 78 & 68 & 75 & 122 & 49 & 80 \\
\hline Leeds-United Kingdom & 62 & 30 & 24 & 91 & 53 & 96 & 146 & 106 & 140 & 81 \\
\hline Liverpool-United Kingdom & 61 & 48 & 10 & 116 & 59 & 103 & 127 & 95 & 122 & 82 \\
\hline Zagreb-Croatia & 126 & 108 & 43 & 27 & 55 & 80 & 119 & 56 & 94 & 83 \\
\hline Lille-France & 70 & 88 & 66 & 84 & 120 & 77 & 83 & 123 & 39 & 84 \\
\hline Seville-Spain & 116 & 98 & 74 & 77 & 105 & 20 & 95 & 105 & 33 & 85 \\
\hline Santiago-Chile & 122 & 91 & 91 & 28 & 107 & 62 & 78 & 77 & 72 & 86 \\
\hline Kuala Lumpur-Malaysia & 81 & 120 & 115 & 85 & 102 & 99 & 40 & 79 & 48 & 87 \\
\hline Porto-Portugal & 106 & 126 & 83 & 15 & 112 & 98 & 38 & 130 & 120 & 88 \\
\hline Málaga-Spain & 123 & 107 & 51 & 89 & 85 & 83 & 99 & 87 & 26 & 89 \\
\hline Bangkok-Thailand & 77 & 123 & 102 & 135 & 136 & 50 & 7 & 59 & 114 & 90 \\
\hline Duisburg-Germany & 86 & 67 & 11 & 109 & 113 & 123 & 100 & 144 & 51 & 91 \\
\hline Palma de Mallorca-Spain & 99 & 114 & 82 & 96 & 88 & 71 & 96 & 47 & 50 & 92 \\
\hline Zaragoza-Spain & 102 & 93 & 71 & 106 & 101 & 67 & 130 & 82 & 28 & 93 \\
\hline Panama City-Panama & 79 & 75 & 110 & 42 & 126 & 121 & 72 & 36 & 125 & 94 \\
\hline Murcia-Spain & 100 & 110 & 56 & 111 & 93 & 43 & 156 & 104 & 24 & 95 \\
\hline Nottingham-United Kingdom & 68 & 41 & 34 & 119 & 65 & 105 & 160 & 93 & 136 & 96 \\
\hline Abu Dhabi-United Arab Emirates & 26 & 149 & 12 & 162 & 87 & 131 & 71 & 9 & 64 & 97 \\
\hline Florence-Italy & 92 & 77 & 100 & 126 & 135 & 125 & 85 & 22 & 30 & 98 \\
\hline Valladolid-Spain & 113 & 102 & 73 & 51 & 95 & 81 & 159 & 129 & 53 & 99 \\
\hline
\end{tabular}

29 IESE Business School - IESE Cities in Motion Index (ST-471-E) 


\section{TABLE 11. RANKING BY DIMENSION (CONTINUED)}

\begin{tabular}{|c|c|c|c|c|c|c|c|c|c|c|}
\hline City & Economy & $\begin{array}{l}\text { Human } \\
\text { Capital }\end{array}$ & $\begin{array}{l}\text { Social } \\
\text { Cohesion }\end{array}$ & Environment & Governance & $\begin{array}{l}\text { Urban } \\
\text { Planning }\end{array}$ & $\begin{array}{l}\text { International } \\
\text { Outreach }\end{array}$ & Technology & $\begin{array}{l}\text { Mobility and } \\
\text { Transportation }\end{array}$ & $\begin{array}{c}\text { Cities in } \\
\text { Motion }\end{array}$ \\
\hline Montevideo-Uruguay & 131 & 136 & 117 & 7 & 54 & 78 & 97 & 83 & 129 & 100 \\
\hline Sofia-Bulgaria & 128 & 79 & 95 & 79 & 61 & 138 & 108 & 68 & 73 & 101 \\
\hline San José-Costa Rica & 107 & 152 & 108 & 6 & 28 & 135 & 89 & 91 & 153 & 102 \\
\hline Bilbao-Spain & 96 & 105 & 85 & 103 & 84 & 86 & 137 & 100 & 92 & 103 \\
\hline Vigo-Spain & 117 & 117 & 63 & 48 & 123 & 79 & 154 & 124 & 74 & 104 \\
\hline A Coruña-Spain & 111 & 113 & 89 & 70 & 128 & 58 & 161 & 120 & 52 & 105 \\
\hline Turin-Italy & 101 & 71 & 106 & 123 & 110 & 92 & 124 & 111 & 34 & 106 \\
\hline Mexico City-Mexico & 94 & 44 & 116 & 147 & 91 & 54 & 37 & 146 & 86 & 107 \\
\hline Minsk-Belarus & 150 & 74 & 42 & 46 & 131 & 110 & 102 & 125 & 81 & 108 \\
\hline Guangzhou-China & 55 & 92 & 121 & 152 & 119 & 124 & 56 & 110 & 27 & 109 \\
\hline Belgrade-Serbia & 130 & 106 & 140 & 31 & 99 & 89 & 84 & 97 & 97 & 110 \\
\hline Doha-Qatar & 30 & 145 & 46 & 158 & 124 & 117 & 88 & 11 & 126 & 111 \\
\hline Tbilisi-Georgia & 104 & 125 & 125 & 39 & 100 & 130 & 116 & 108 & 103 & 112 \\
\hline Kiev-Ukraine & 148 & 86 & 157 & 121 & 103 & 6 & 60 & 76 & 83 & 113 \\
\hline Istanbul-Turkey & 87 & 118 & 155 & 124 & 139 & 106 & 18 & 26 & 124 & 114 \\
\hline Shenzhen-China & 39 & 104 & 135 & 150 & 137 & 143 & 66 & 121 & 32 & 115 \\
\hline São Paulo-Brazil & 155 & 103 & 145 & 90 & 121 & 34 & 28 & 72 & 88 & 116 \\
\hline Bogota-Colombia & 124 & 90 & 143 & 62 & 48 & 136 & 68 & 103 & 151 & 117 \\
\hline Almaty-Kazakhstan & 146 & 121 & 49 & 100 & 147 & 84 & 152 & 115 & 35 & 118 \\
\hline Naples-Italy & 119 & 89 & 114 & 105 & 144 & 88 & 94 & 136 & 101 & 119 \\
\hline Ankara-Turkey & 125 & 100 & 111 & 137 & 127 & 87 & 117 & 112 & 57 & 120 \\
\hline Jerusalem-Israel & 95 & 131 & 139 & 53 & 66 & 128 & 120 & 119 & 141 & 121 \\
\hline Athens-Greece & 135 & 69 & 160 & 61 & 146 & 109 & 52 & 40 & 89 & 122 \\
\hline Saint Petersburg-Russia & 137 & 25 & 137 & 125 & 92 & 115 & 61 & 113 & 127 & 123 \\
\hline Ho Chi Minh City-Vietnam & 109 & 150 & 119 & 76 & 133 & 137 & 77 & 127 & 111 & 124 \\
\hline Skopje-Macedonia & 112 & 148 & 133 & 81 & 109 & 122 & 147 & 99 & 117 & 125 \\
\hline Rio de Janeiro-Brazil & 160 & 94 & 154 & 102 & 77 & 36 & 47 & 88 & 133 & 126 \\
\hline Baku-Azerbaijan & 141 & 112 & 127 & 60 & 153 & 142 & 135 & 89 & 106 & 127 \\
\hline Kuwait City-Kuwait & 93 & 153 & 65 & 142 & 108 & 154 & 118 & 35 & 130 & 128 \\
\hline Medellín-Colombia & 132 & 128 & 124 & 71 & 116 & 126 & 113 & 153 & 121 & 129 \\
\hline Rosario-Argentina & 158 & 122 & 57 & 114 & 141 & 35 & 144 & 141 & 123 & 130 \\
\hline Lima-Peru & 115 & 111 & 130 & 122 & 86 & 146 & 81 & 143 & 158 & 131 \\
\hline Sarajevo-Bosnia and Herzegovina & 153 & 115 & 151 & 95 & 130 & 69 & 143 & 135 & 62 & 132 \\
\hline
\end{tabular}




\section{TABLE 11. RANKING BY DIMENSION (CONTINUED)}

\begin{tabular}{|c|c|c|c|c|c|c|c|c|c|c|}
\hline City & Economy & $\begin{array}{l}\text { Human } \\
\text { Capital }\end{array}$ & $\begin{array}{l}\text { Social } \\
\text { Cohesion }\end{array}$ & Environment & Governance & $\begin{array}{l}\text { Urban } \\
\text { Planning }\end{array}$ & $\begin{array}{l}\text { International } \\
\text { Outreach }\end{array}$ & Technology & $\begin{array}{l}\text { Mobility and } \\
\text { Transportation }\end{array}$ & $\begin{array}{l}\text { Cities in } \\
\text { Motion }\end{array}$ \\
\hline Tunis-Tunisia & 136 & 146 & 113 & 58 & 129 & 140 & 139 & 149 & 146 & 134 \\
\hline Curitiba-Brazil & 161 & 139 & 123 & 65 & 132 & 116 & 122 & 117 & 109 & 135 \\
\hline Jakarta-Indonesia & 114 & 133 & 126 & 140 & 114 & 153 & 31 & 132 & 164 & 136 \\
\hline Cali-Colombia & 139 & 135 & 99 & 80 & 122 & 133 & 153 & 160 & 148 & 137 \\
\hline Brasilia-Brazil & 163 & 138 & 144 & 82 & 125 & 127 & 91 & 142 & 61 & 138 \\
\hline Amman-Jordan & 145 & 157 & 103 & 115 & 106 & 149 & 138 & 64 & 160 & 139 \\
\hline Quito-Ecuador & 157 & 127 & 105 & 88 & 160 & 132 & 107 & 133 & 128 & 140 \\
\hline Guatemala City-Guatemala & 144 & 162 & 118 & 44 & 134 & 157 & 93 & 158 & 142 & 141 \\
\hline Novosibirsk-Russia & 142 & 119 & 128 & 131 & 118 & 141 & 129 & 148 & 138 & 142 \\
\hline Cape Town-South Africa & 143 & 134 & 156 & 117 & 98 & 148 & 76 & 138 & 155 & 143 \\
\hline Manama-Bahrain & 90 & 142 & 41 & 159 & 145 & 165 & 151 & 58 & 95 & 144 \\
\hline Santa Cruz-Bolivia & 140 & 143 & 152 & 29 & 158 & 156 & 155 & 150 & 137 & 145 \\
\hline Manila-Philippines & 121 & 141 & 122 & 153 & 143 & 152 & 39 & 147 & 162 & 146 \\
\hline Salvador-Brazil & 164 & 129 & 142 & 86 & 140 & 120 & 134 & 152 & 132 & 147 \\
\hline Casablanca-Morocco & 134 & 164 & 131 & 130 & 159 & 150 & 110 & 102 & 147 & 148 \\
\hline Tianjin-China & 40 & 109 & 134 & 165 & 150 & 139 & 150 & 134 & 115 & 149 \\
\hline Guayaquil-Ecuador & 159 & 144 & 104 & 92 & 161 & 144 & 149 & 157 & 152 & 150 \\
\hline Belo Horizonte-Brazil & 162 & 132 & 136 & 120 & 142 & 134 & 136 & 140 & 149 & 151 \\
\hline La Paz-Bolivia & 152 & 147 & 149 & 94 & 148 & 147 & 141 & 162 & 145 & 152 \\
\hline Riyadh-Saudi Arabia & 85 & 155 & 112 & 164 & 80 & 158 & 128 & 54 & 135 & 153 \\
\hline Santo Domingo-Dominican Republic & 97 & 161 & 164 & 145 & 155 & 114 & 125 & 151 & 134 & 154 \\
\hline Rabat-Morocco & 147 & 158 & 150 & 112 & 157 & 151 & 158 & 155 & 156 & 155 \\
\hline Johannesburg-South Africa & 149 & 140 & 161 & 141 & 115 & 145 & 148 & 145 & 143 & 156 \\
\hline Cairo-Egypt & 129 & 137 & 158 & 154 & 162 & 119 & 86 & 128 & 159 & 157 \\
\hline Mumbai-India & 127 & 154 & 138 & 156 & 138 & 160 & 57 & 137 & 161 & 158 \\
\hline New Delhi-India & 103 & 151 & 141 & 163 & 149 & 163 & 63 & 156 & 154 & 159 \\
\hline Douala-Cameroon & 138 & 156 & 132 & 97 & 164 & 159 & 165 & 163 & 144 & 160 \\
\hline Nairobi-Kenya & 120 & 160 & 162 & 148 & 154 & 155 & 140 & 159 & 163 & 161 \\
\hline Caracas-Venezuela & 165 & 101 & 159 & 129 & 156 & 101 & 82 & 165 & 139 & 162 \\
\hline Kolkata-India & 133 & 165 & 153 & 157 & 151 & 161 & 142 & 161 & 165 & 163 \\
\hline Lagos-Nigeria & 154 & 159 & 163 & 155 & 165 & 162 & 164 & 164 & 157 & 164 \\
\hline Karachi-Pakistan & 118 & 163 & 165 & 161 & 163 & 164 & 163 & 154 & 150 & 165 \\
\hline
\end{tabular}

31 IESE Business School - IESE Cities in Motion Index (ST-471-E) 
FIGURE 2. MAP OF CITIES IN THE CIMI RANKING

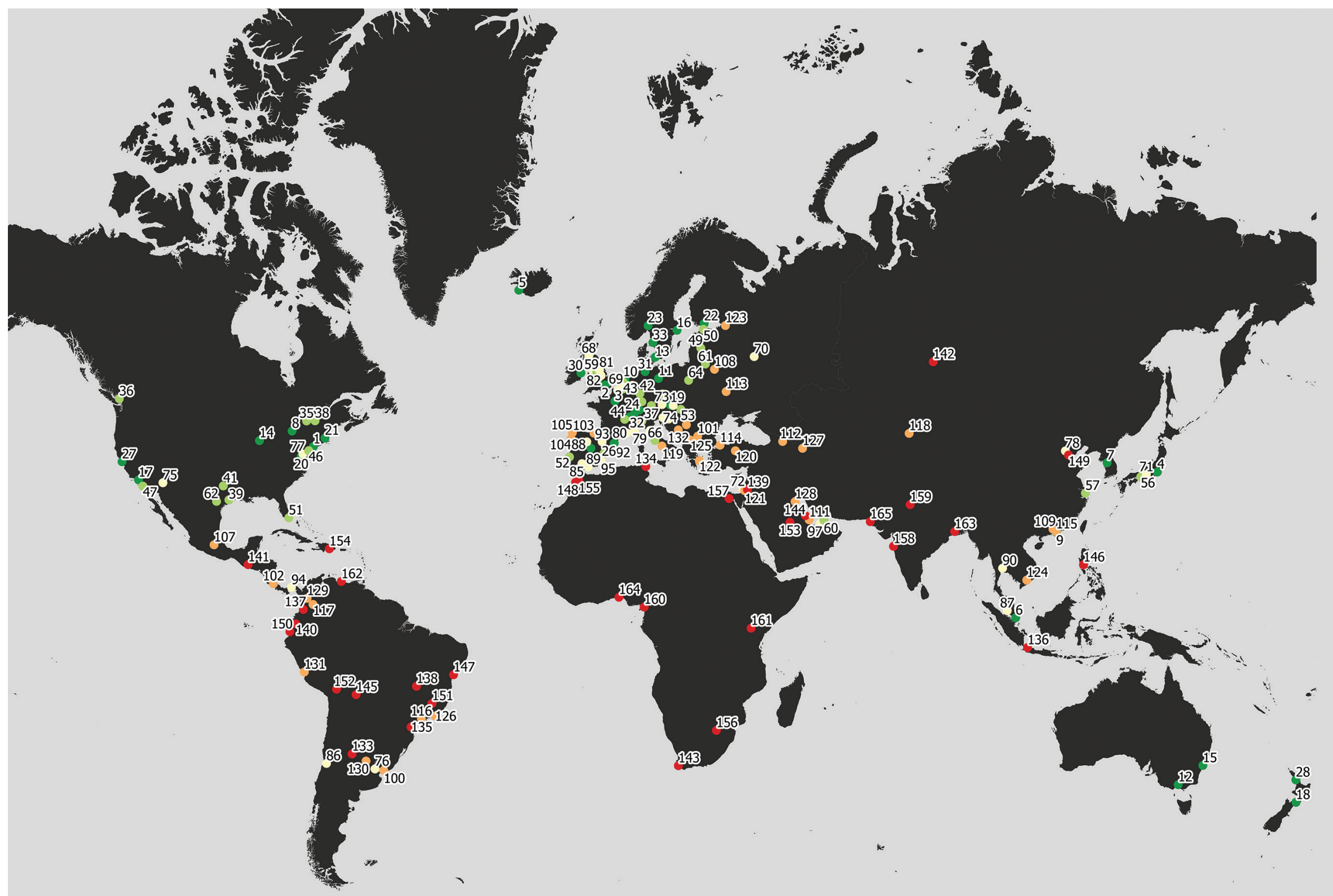


Table 12 shows the top 10 positions in the ranking for each dimension. In this way, we can visualize better the regional representativeness in the various dimensions.

\section{THE ECONOMY}

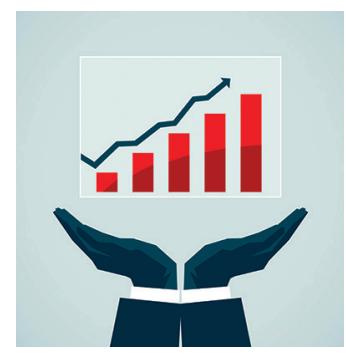

The city that leads the ranking in this dimension is New York (United States), which achieves relatively high levels in all indicators but stands out especially for its high GDP and for the number of publicly traded parent companies. It is worth noting that there are a total of six U.S. cities in the top 10 for this dimension.

\section{HUMAN CAPITAL}

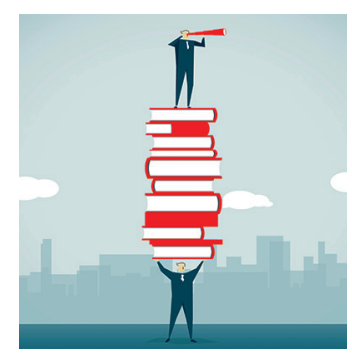

The city that ranks first in this dimension is London (United Kingdom), which stands out for having the most top-level business schools, as well as for having the highest number of universities. In addition, a high proportion of the population has secondary and higher education and it is a city with a broad cultural offering made up of theaters, museums and art galleries.

Although London leads this dimension, the top 10 contains five U.S. cities, as shown in Table 12.

\section{SOCIAL COHESION}

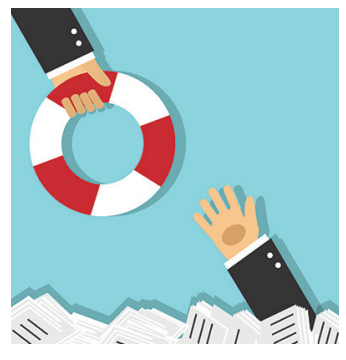

Helsinki (Finland) is the city with the highest rating in this dimension. It is a city with a low unemployment rate, an equitable distribution of income and the highest percentage of women in positions of responsibility (more than 70\%).

Of the top 10 cities in the ranking for this dimension, nine are European.

\section{THE ENVIRONMENT}

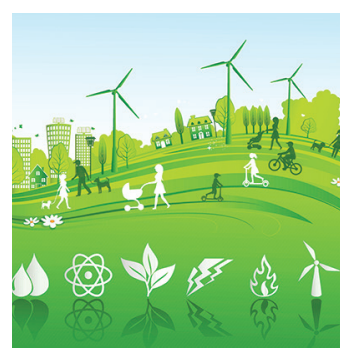

In this dimension, the cities with the highest positions are Reykjavik (Iceland) and Wellington (New Zealand). They are at the top of the Environmental Performance Index (EPI) and have low levels of PM10 and PM2.5 pollution. Moreover, Reykjavik also stands out for its renewable water sources. This year, two new entries from Central and South America stand out in the top 10 of this ranking: San José and Montevideo. 


\section{GOVERNANCE}

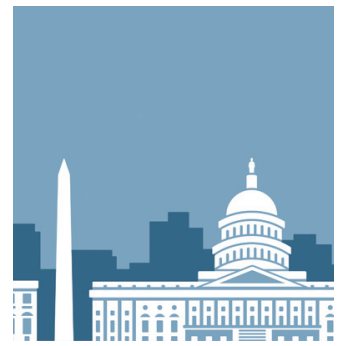

Bern (Switzerland) is ranked first in this dimension, displaying a good performance in the indexes of corruption perceptions, reserves per capita and number of embassies. Of the top 10 cities in the ranking for this dimension, three are Swiss.

\section{URBAN PLANNING}

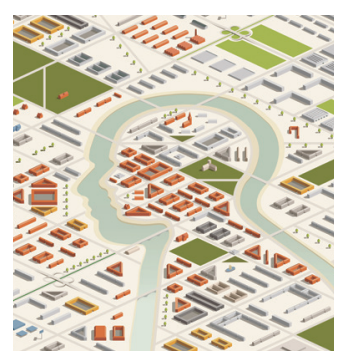

New York (United States) ranks first in this dimension. It is notable for its very well-developed infrastructure, with a large number of buildings and skyscrapers. It is worth noting that almost $100 \%$ of the population has access to adequate sanitation facilities and that the city has a low number of people per household. It is worth mentioning that six North American cities are in the top 10 for this dimension, four of which are Canadian.

\section{INTERNATIONAL OUTREACH}

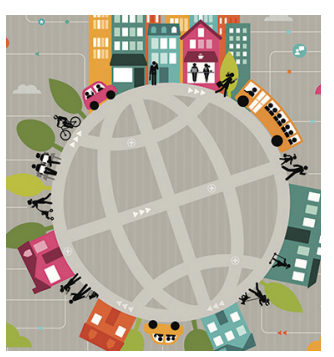

Just as last year, Paris (France) is the top-ranking city for this dimension and London (United Kingdom) is in second place. Paris is the city with the second-highest number of international tourists and ranks fourth in the ranking of cities with the most photos uploaded to Panoramio. It is also the city where the most international conferences and meetings are organized. London, in turn, is the city that attracts a higher number of airline passengers, which is consistent with the fact that it is one of the cities with the largest number of air routes. In addition, both cities stand out for the number of hotels they have.

Of the top 10 cities for this dimension, five are European, two are North American and two are Asian.

\section{TECHNOLOGY}

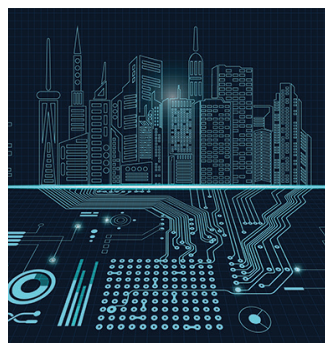

Hong Kong (China) is in the top position of this ranking. This city has a high innovation index, almost $100 \%$ of its population have mobile telephones, and it has a high number of wireless access points globally. It also stands out for the number of social media users and the number of mobile phones per capita.

Of the cities that occupy the top 10 positions, three are in the Asia-Pacific region, three are European and two are in the Middle East.

\section{MOBILITY AND TRANSPORTATION}

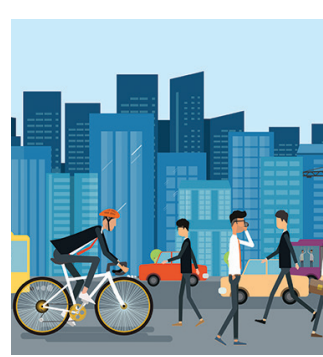

Paris (France) is first in this ranking and is notable for its metro system, the development of its bike-sharing system, its high-speed train and the number of air routes arriving in the city. Six European and three Asian cities can be found in the top 10 positions for this dimension. 


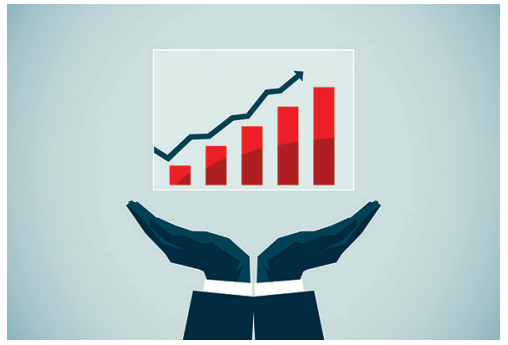

\section{ECONOMY}

\begin{tabular}{|c|c|c|}
\hline 1 & New York-United States & London \\
\hline 2 & Tokyo-Japan & Los Ang \\
\hline 3 & Los Angeles-United States & Boston- \\
\hline 4 & London-United Kingdom & New Yo \\
\hline 5 & Stockholm-Sweden & Tokyo-J \\
\hline 6 & San Francisco-United States & v \\
\hline 7 & Paris-France & t \\
\hline 8 & Houston-United States & Paris-Fr \\
\hline 9 & Dallas-United States & Moscov \\
\hline 10 & Chicago-United States & Chicagc \\
\hline
\end{tabular}

\section{THE ENVIRONMENT}

$\begin{array}{ll}\mathbf{1} & \text { Reykjavik-Iceland } \\ \mathbf{2} & \text { Wellington-New Zealand } \\ \mathbf{3} & \text { Copenhagen-Denmark } \\ \mathbf{4} & \text { Tallinn-Estonia } \\ \mathbf{5} & \text { Riga-Latvia } \\ \mathbf{6} & \text { San José-Costa Rica } \\ \mathbf{7} & \text { Montevideo-Uruguay } \\ \mathbf{8} & \text { Stockholm-Sweden } \\ \mathbf{9} & \text { Lisbon-Portugal } \\ \mathbf{1 0} & \text { Singapore-Singapore }\end{array}$

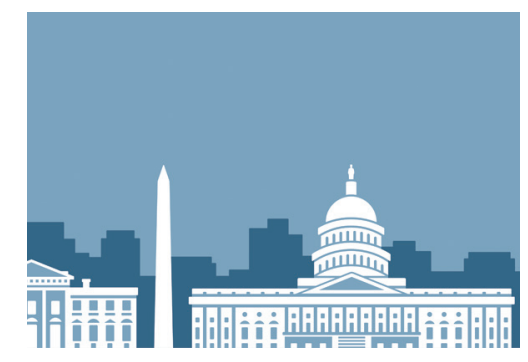

GOVERNANCE

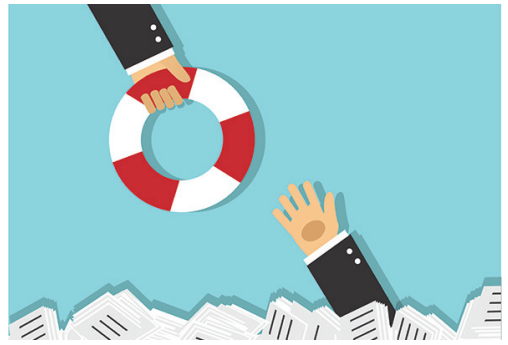

SOCIAL COHESION

Helsinki-Finland

Bern-Switzerland

Berlin-Germany

Zurich-Switzerland

Basel-Switzerland

Linz-Austria

Eindhoven-Netherlands

Melbourne-Australia

Munich-Germany

Liverpool-United Kingdom 


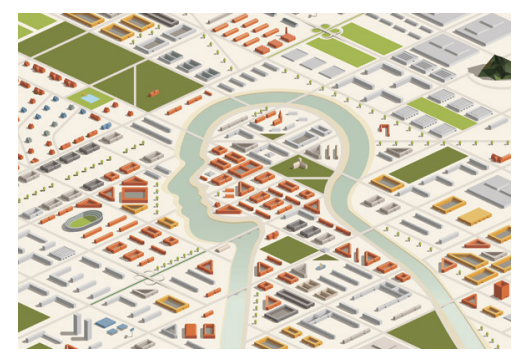

URBAN PLANNING

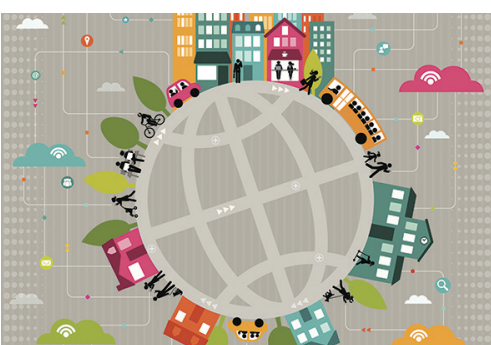

INTERNATIONAL OUTREACH

$\begin{array}{lll}\mathbf{1} & \text { New York-United States } & \text { Paris-France } \\ \mathbf{2} & \text { Toronto-Canada } & \text { London-United Kingdom } \\ \mathbf{3} & \text { Paris-France } & \text { New York-United States } \\ \mathbf{4} & \text { Vancouver-Canada } & \text { Berlin-Germany } \\ \mathbf{5} & \text { Chicago-United States } & \text { Singapore-Singapore } \\ \mathbf{6} & \text { Kiev-Ukraine } & \text { Amsterdam-Netherlands } \\ \mathbf{7} & \text { London-United Kingdom } & \text { Bangkok-Thailand } \\ \mathbf{8} & \text { Ottawa-Canada } & \text { Vienna-Austria } \\ \mathbf{9} & \text { Montreal-Canada } & \text { Chicago-United States } \\ \mathbf{1 0} & \text { Hong Kong-China } & \text { Melbourne-Australia }\end{array}$

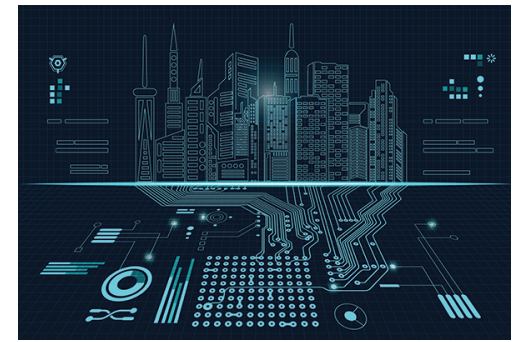

TECHNOLOGY

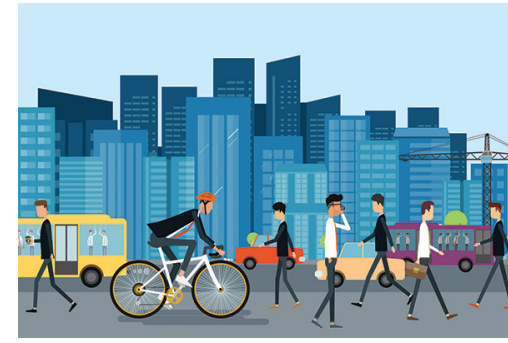

MOBILITY AND TRANSPORTATION

$\begin{array}{lll}\mathbf{1} & \text { Hong Kong-China } & \text { Paris-France } \\ \mathbf{2} & \text { Singapore-Singapore } & \text { London-United Kingdom } \\ \mathbf{3} & \text { Amsterdam-Netherlands } & \text { Seoul-South Korea } \\ \mathbf{4} & \text { Dubai-United Arab Emirates } & \text { New York-United States } \\ \mathbf{5} & \text { New York-United States } & \text { Shanghai-China } \\ \mathbf{6} & \text { London-United Kingdom } & \text { Berlin-Germany } \\ \mathbf{7} & \text { Reykjavik-Iceland } & \text { Reykjavik-Iceland } \\ \mathbf{8} & \text { Sydney-Australia } & \text { Munich-Germany } \\ \mathbf{9} & \text { Abu Dhabi-United Arab Emirates } & \text { Madrid-Spain } \\ \mathbf{1 0} & \text { Seoul-South Korea } & \text { Beijing-China }\end{array}$


"IN ORDER TO EXECUTE THE STRATEGIC PLANS, IT IS NECESSARY TO ACKNOWLEDGE THAT CITIES CANNOT DO IT ALL ALONE. THE TRANSFORMATION OF A CITY IS NOT AN INDIVIDUAL UNDERTAKING BUT INSTEAD A COLLECTIVE ENDEAVOR, SO COLLABORATION IS ESSENTIAL".
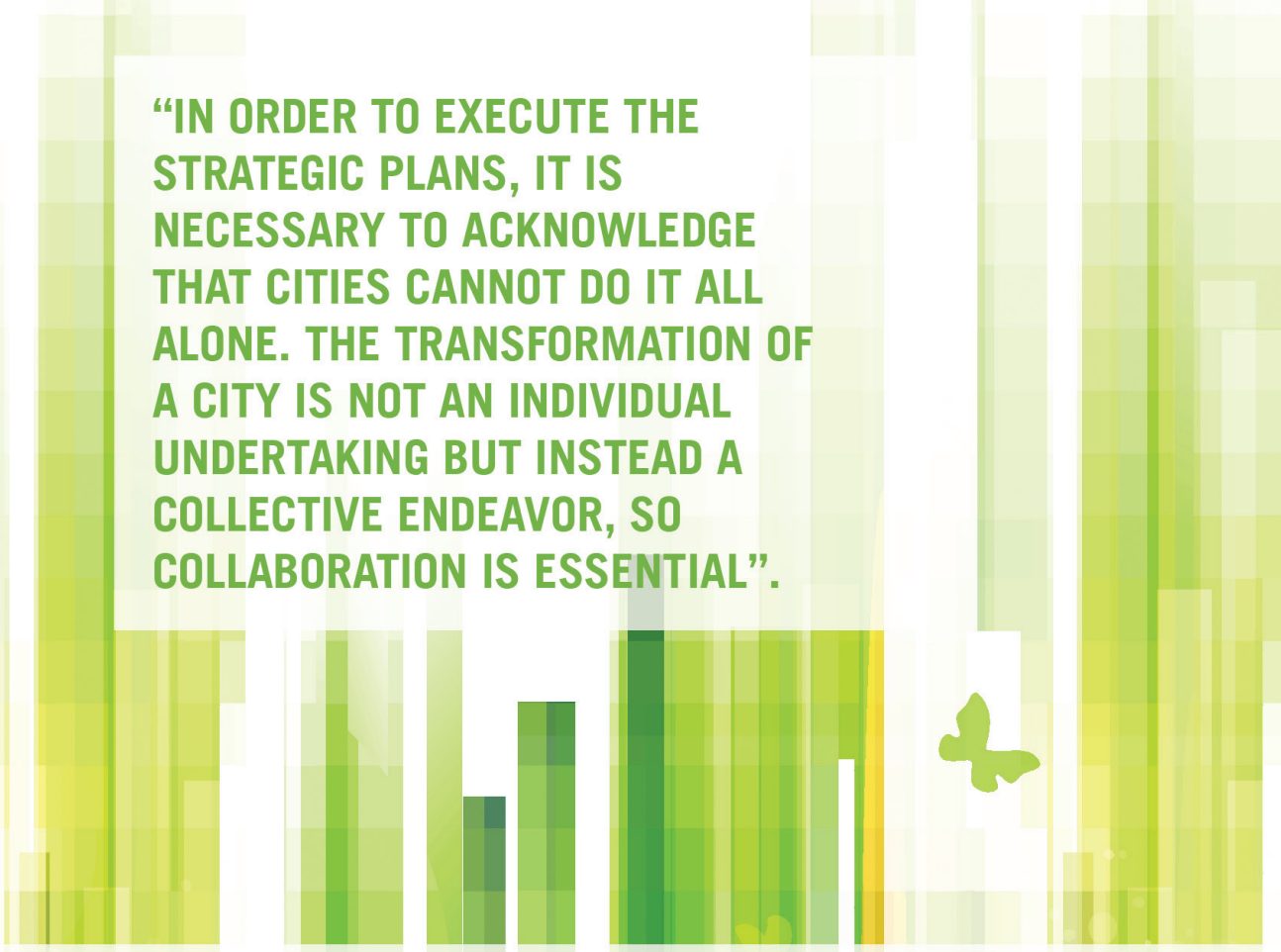

\section{Pascual Berrone \& Joan Enric Ricart}
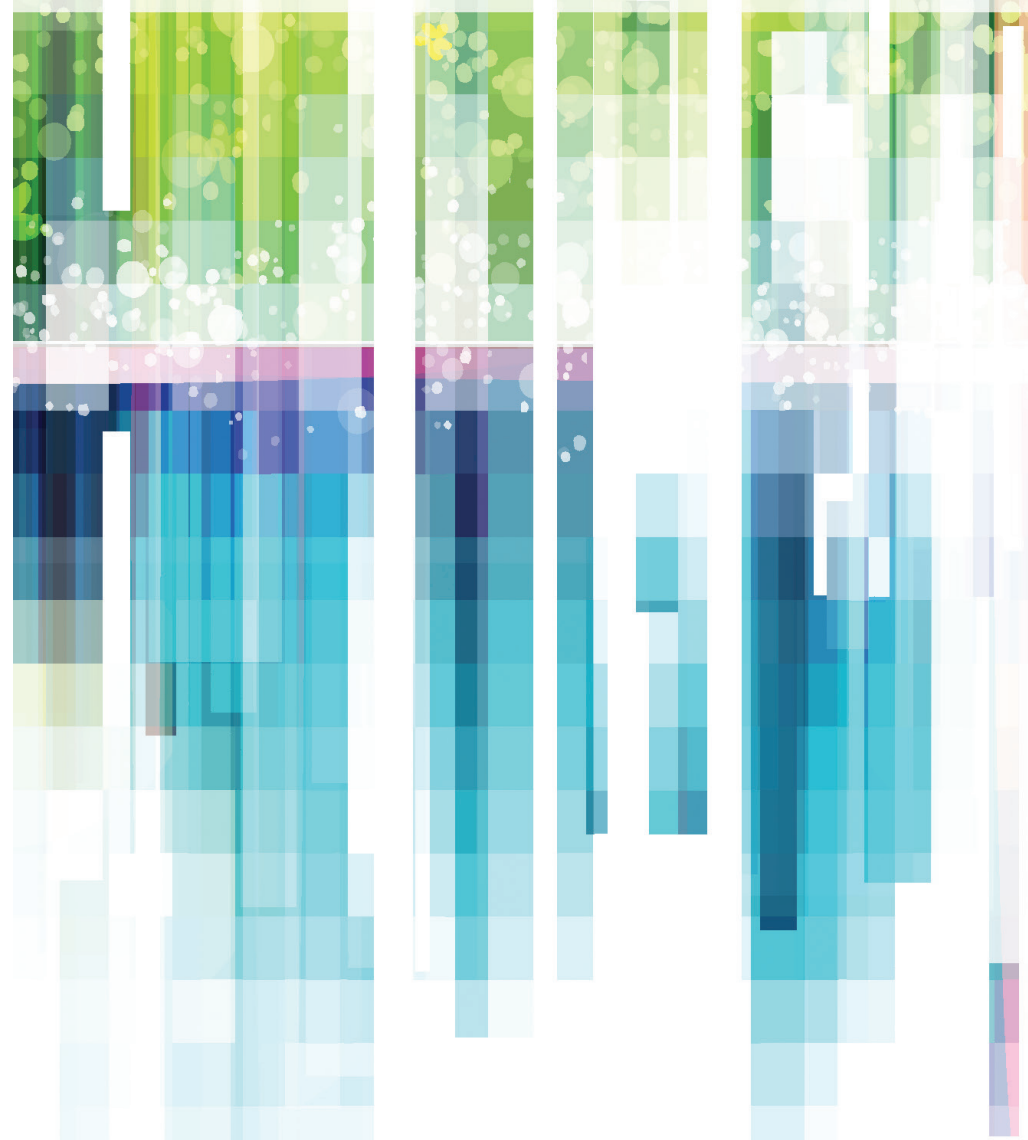

"THE FIRST STEP FOR

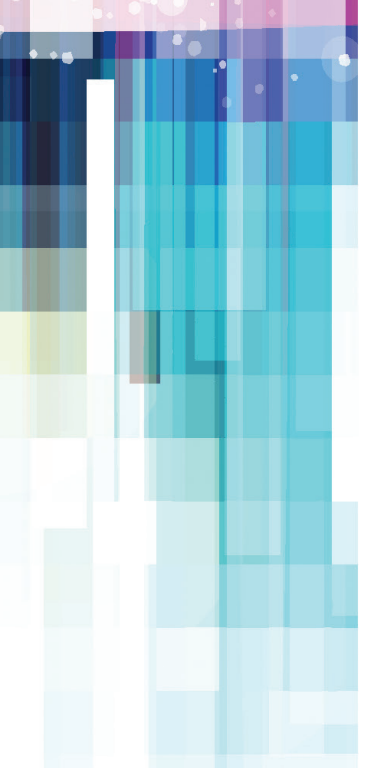

DEVELOPING A STRATEGIC PLAN IS A GOOD DIAGNOSIS, AND THE CIMI IS A TOOL FOR TAKING A QUICK X-RAY OF A CITY'S STRENGTHS AND WEAKNESSES AND FOR IDENTIFYING OTHER CITIES THAT MIGHT SERVE AS A BENCHMARK TO BEGIN THE NECESSARY CHANGE". 


\section{CITIES IN MOTION. REGIONAL RANKING}

This section takes into account the ranking according to the geographical region. Below are the regional maps and corresponding tables of the top five cities in each region.

* Please click on the maps for a larger and more detailed version.

TOP 5 WESTERN EUROPE

\begin{tabular}{lcccc} 
CITY & REGIONAL & GLOBAL & GLOBAL & GLOBAL \\
& POSITION & POSITION & POSITION & POSITION \\
& & 2015 & 2016 & 2017 \\
\hline
\end{tabular}

\begin{tabular}{lcccc}
\hline $\begin{array}{l}\text { London, United } \\
\text { Kingdom }\end{array}$ & 1 & 1 & 2 & 2 \\
\hline Paris, France & 2 & 3 & 3 & 3 \\
\hline Reykjavik, Iceland & 3 & 5 & 5 & 5 \\
\hline $\begin{array}{l}\text { Amsterdam, } \\
\text { Netherlands }\end{array}$ & 4 & 11 & 11 & 10 \\
\hline \begin{tabular}{l} 
Berlin, Germany \\
\hline
\end{tabular} & 5 & 10 & 10 & 11
\end{tabular}

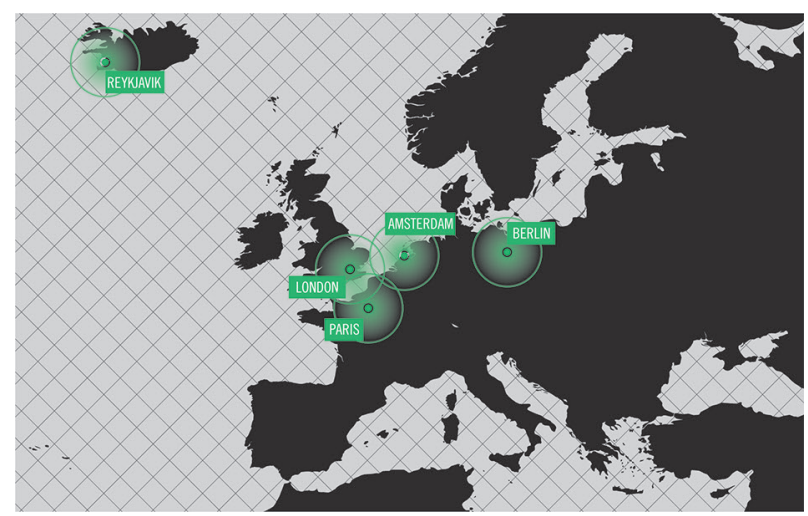

London leads the ranking in Europe, while occupying second place in the world ranking. The next highest-ranking cities in Europe are Paris, Reykjavik and Amsterdam. Berlin completes the regional ranking. As seen in the table, four cities in the regional top five are in the top 10 in the overall ranking.

TOP 5 EASTERN EUROPE

\begin{tabular}{lcccc} 
CITY & $\begin{array}{c}\text { REGIONAL } \\
\text { POSITION }\end{array}$ & $\begin{array}{c}\text { GLOBAL } \\
\text { POSITION } \\
\mathbf{2 0 1 5}\end{array}$ & $\begin{array}{c}\text { GLOBAL } \\
\text { POSITION } \\
\mathbf{2 0 1 6}\end{array}$ & $\begin{array}{c}\text { GLOBAL } \\
\text { POSITION } \\
\mathbf{2 0 1 7}\end{array}$ \\
\hline $\begin{array}{l}\text { Prague, Czech } \\
\text { Republic }\end{array}$ & 1 & 43 & 40 & 40 \\
\hline Riga, Latvia & 2 & 45 & 48 & 49 \\
\hline Tallinn, Estonia & 3 & 40 & 42 & 50 \\
\hline Budapest, Hungary & 4 & 50 & 51 & 53 \\
\hline Vilnius, Lithuania & 5 & 59 & 56 & 61 \\
\hline
\end{tabular}

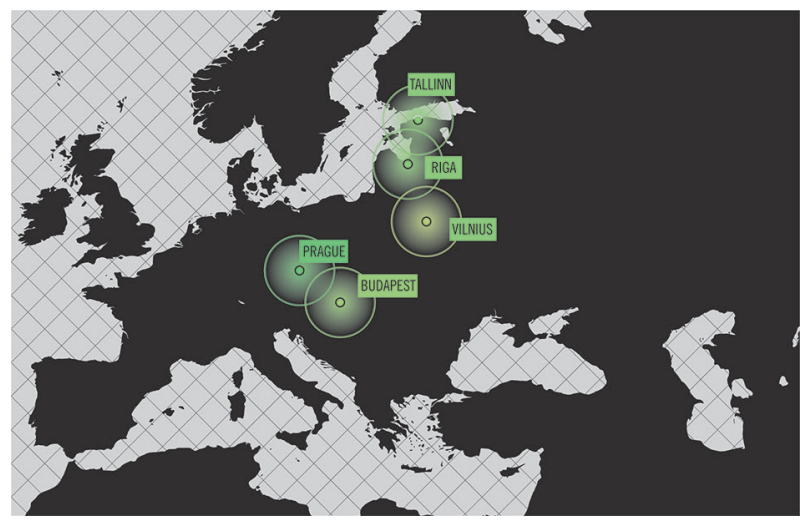

The eastern Europe list is led by Prague, a city that is also in the top 30 in the dimensions of technology, the environment and international outreach. It is followed by Riga, Tallinn, Budapest and Vilnius. 
TOP 5 LATIN AMERICA

\begin{tabular}{lcccc} 
CITY & $\begin{array}{c}\text { REGIONAL } \\
\text { POSITION }\end{array}$ & $\begin{array}{c}\text { GLOBAL } \\
\text { POSITION } \\
\mathbf{2 0 1 5}\end{array}$ & $\begin{array}{c}\text { GLOBAL } \\
\text { POSITION } \\
\mathbf{2 0 1 6}\end{array}$ & $\begin{array}{c}\text { GLOBAL } \\
\text { POSITION } \\
\mathbf{2 0 1 7}\end{array}$ \\
\hline $\begin{array}{l}\text { Buenos Aires, } \\
\text { Argentina }\end{array}$ & 1 & 84 & 79 & 76 \\
\hline Santiago, Chile & 2 & 83 & 75 & 86 \\
\hline Panama City, Panama & 3 & 91 & 99 & 94 \\
\hline Montevideo, Uruguay & 4 & 88 & 92 & 100 \\
\hline San José, Costa Rica & 5 & 102 & 103 & 102 \\
\hline
\end{tabular}

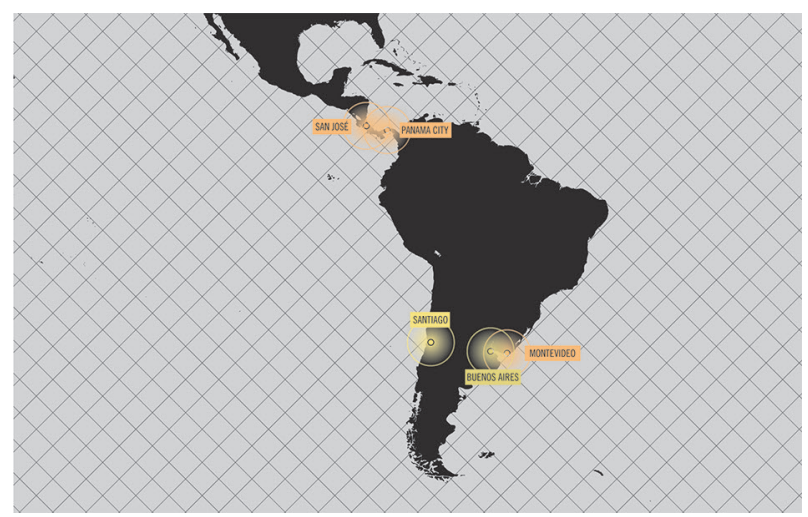

Buenos Aires leads the ranking among the best Latin American cities, rising eight places in the past two years. This city is in the top 30 for the dimensions of urban planning, international outreach and governance. In second position in the regional ranking is the city of Santiago, followed by Panama City. The cities of San José and Montevideo complete the ranking. Although the city of Montevideo occupies position 100 in the overall ranking, it stands out in the environment dimension in position 7.

As can be seen in the table and in the map above, most of the Latin American cities are below position 100 in the overall ranking, with the exception of Buenos Aires, Santiago and Panama City. Latin America is one of the regions with the greatest urban concentration on the planet, so the challenges facing these cities are increasingly global, with problems common to all of them.

TOP 5 ASIA-PACIFIC

\begin{tabular}{lcccc} 
CITY & $\begin{array}{c}\text { REGIONAL } \\
\text { POSITION }\end{array}$ & $\begin{array}{c}\text { GLOBAL } \\
\text { POSITION } \\
\mathbf{2 0 1 5}\end{array}$ & $\begin{array}{c}\text { GLOBAL } \\
\text { POSITION } \\
\mathbf{2 0 1 6}\end{array}$ & $\begin{array}{c}\text { GLOBAL } \\
\text { POSITION } \\
\mathbf{2 0 1 7}\end{array}$ \\
\hline Tokyo, Japan & 1 & 4 & 4 & 4 \\
\hline Singapore, Singapore & 2 & 6 & 6 & 6 \\
\hline Seoul, South Korea & 3 & 7 & 7 & 7 \\
\hline Hong Kong, China & 4 & 8 & 9 & 9 \\
\hline Osaka, Japan & 5 & 55 & 55 & 56 \\
\hline
\end{tabular}

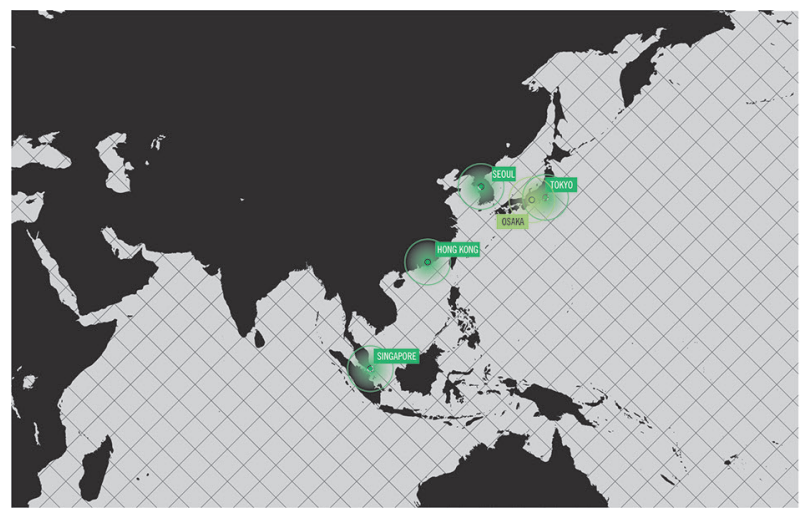

Tokyo leads the ranking in the Asia-Pacific region and is ranked fourth overall, a position it has held for the past two years. Tokyo stands out especially in the economy and human capital dimensions, where it occupies second and fifth places respectively. The second city in the regional ranking is Singapore, which ranks sixth in the overall ranking. This city stands out in technology, governance and the environment, featuring in the top 10 for these dimensions. The cities of Seoul, Hong Kong and Osaka complete the regional ranking. It is interesting to note that, except for Osaka, the other four cities that lead the region are in the top 10 of the overall ranking. 
TOP 5 MIDDLE EAST

\begin{tabular}{lcccc} 
CITY & $\begin{array}{c}\text { REGIONAL } \\
\text { POSITION }\end{array}$ & $\begin{array}{c}\text { GLOBAL } \\
\text { POSITION } \\
\mathbf{2 0 1 5}\end{array}$ & $\begin{array}{c}\text { GLOBAL } \\
\text { POSITION } \\
\mathbf{2 0 1 6}\end{array}$ & $\begin{array}{c}\text { GLOBAL } \\
\text { POSITION } \\
\mathbf{2 0 1 7}\end{array}$ \\
\hline $\begin{array}{l}\text { Dubai, United Arab } \\
\text { Emirates }\end{array}$ & 1 & 61 & 69 & 60 \\
\hline Tel Aviv, Israel & 2 & 74 & 74 & 72 \\
\hline $\begin{array}{l}\text { Abu Dhabi, United } \\
\text { Arab Emirates }\end{array}$ & 3 & 104 & 113 & 97 \\
\hline Doha, Qatar & 4 & 99 & 111 & 111 \\
\hline Jerusalem, Israel & 5 & 122 & 115 & 121 \\
\hline
\end{tabular}

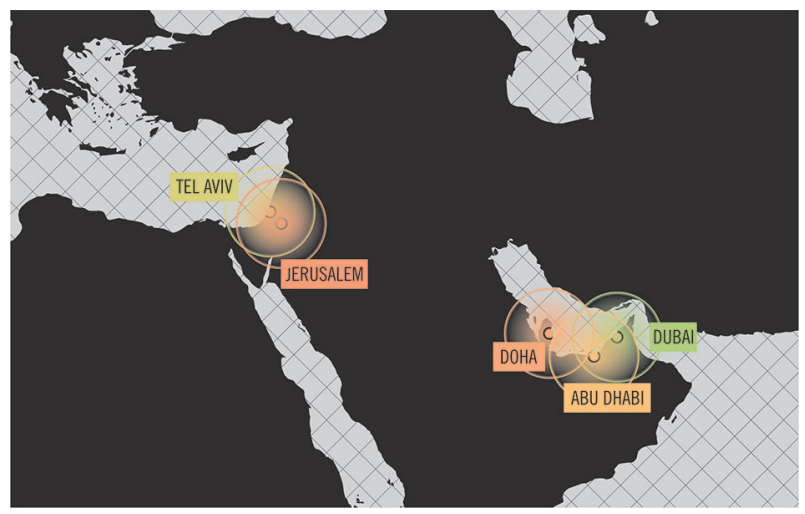

The Middle East ranking is headed by the city of Dubai, which is in position number 60 of the overall ranking. This city stands out in technology and in international outreach, in positions four and 13 respectively. It is followed by Tel Aviv, with Abu Dhabi, Doha and Jerusalem completing the regional ranking of the five best cities.

\section{TOP 5 AFRICA}

\begin{tabular}{lcccc} 
CITY & $\begin{array}{c}\text { REGIONAL } \\
\text { POSITION }\end{array}$ & $\begin{array}{c}\text { GLOBAL } \\
\text { POSITION } \\
\mathbf{2 0 1 5}\end{array}$ & $\begin{array}{c}\text { GLOBAL } \\
\text { POSITION } \\
\mathbf{2 0 1 6}\end{array}$ & $\begin{array}{c}\text { GLOBAL } \\
\text { POSITION } \\
\mathbf{2 0 1 7}\end{array}$ \\
\hline \begin{tabular}{l} 
Tunis, Tunisia \\
\hline $\begin{array}{l}\text { Cape Town, South } \\
\text { Africa }\end{array}$
\end{tabular} & 2 & 146 & 137 & 134 \\
\hline $\begin{array}{l}\text { Casablanca, Morocco } \\
\text { Rabat, Morocco }\end{array}$ & 3 & 150 & 146 & 148 \\
\hline $\begin{array}{l}\text { Johannesburg, South } \\
\text { Africa }\end{array}$ & 5 & 156 & 155 & 155 \\
\hline
\end{tabular}

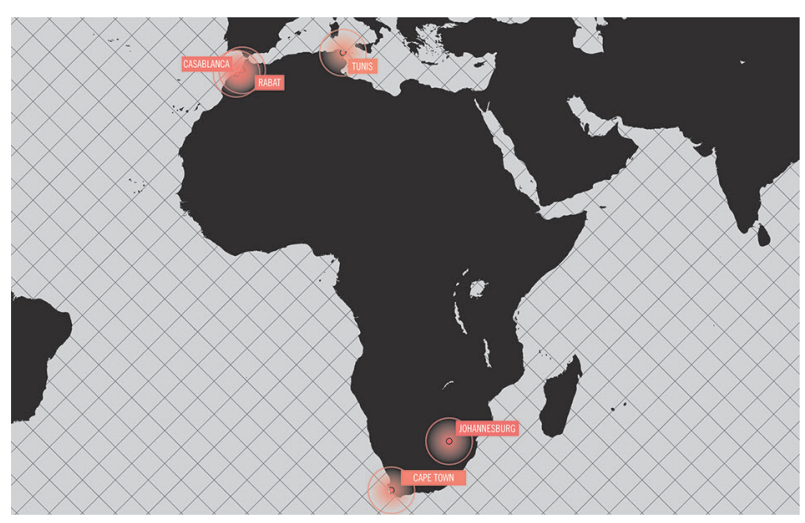

Africa's ranking is headed by the city of Tunis, followed by the South African city of Cape Town. Completing the list of the top five in the region are Casablanca, Rabat, and Johannesburg. It is worth noting that all of the African cities included in the index are among the lowest positions in the overall ranking. 
TOP 5 NORTH AMERICA

\begin{tabular}{lcccc} 
CITY & $\begin{array}{c}\text { REGIONAL } \\
\text { POSITION }\end{array}$ & $\begin{array}{c}\text { GLOBAL } \\
\text { POSITION } \\
\mathbf{2 0 1 5}\end{array}$ & $\begin{array}{c}\text { GLOBAL } \\
\text { POSITION } \\
\mathbf{2 0 1 6}\end{array}$ & $\begin{array}{c}\text { GLOBAL } \\
\text { POSITION } \\
\mathbf{2 0 1 7}\end{array}$ \\
\hline $\begin{array}{l}\text { New York City, United } \\
\text { States }\end{array}$ & 1 & 2 & 1 & 1 \\
\hline $\begin{array}{l}\text { Toronto, Canada } \\
\text { Chicago, United States }\end{array}$ & 2 & 9 & 8 & 8 \\
\hline $\begin{array}{l}\text { Los Angeles, United } \\
\text { States }\end{array}$ & 4 & 14 & 15 & 17 \\
\hline $\begin{array}{l}\text { Washington, D.C., } \\
\text { United States }\end{array}$ & 5 & 21 & 17 & 20 \\
\hline
\end{tabular}

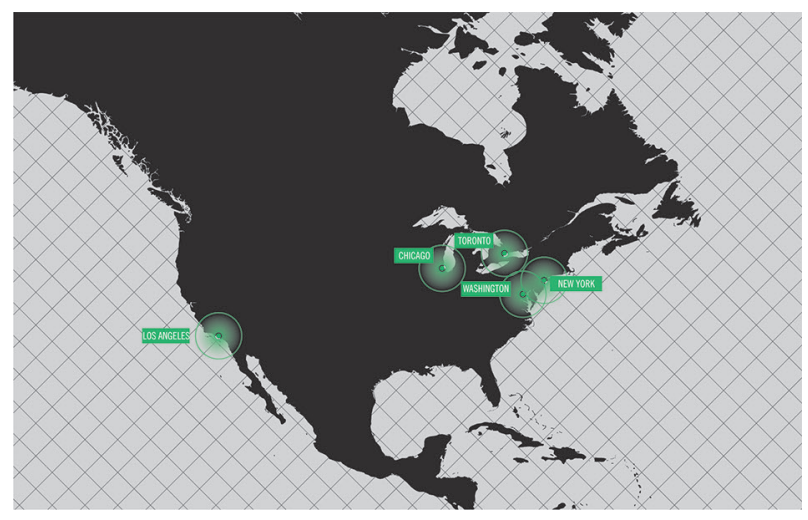

In North America, the ranking is led by New York City, which is also in first position in the overall classification. It is followed by Toronto, which is eighth in the overall ranking. Chicago, Los Angeles, and Washington complete the top five. It should be noted that Toronto is the only city within the regional ranking that is not in the United States.

As can be seen in the table above, North American cities occupy some of the top places in the overall ranking. In the case of the United States, six of the 12 U.S. cities included in the study are among the top 30 in the overall ranking.

\section{TOP 3 OCEANIA}

\begin{tabular}{lcccc} 
CITY & $\begin{array}{c}\text { REGIONAL } \\
\text { POSITION }\end{array}$ & $\begin{array}{c}\text { GLOBAL } \\
\text { POSITION } \\
\mathbf{2 0 1 5}\end{array}$ & $\begin{array}{c}\text { GLOBAL } \\
\text { POSITION } \\
\mathbf{2 0 1 6}\end{array}$ & $\begin{array}{c}\text { GLOBAL } \\
\text { POSITION } \\
\mathbf{2 0 1 7}\end{array}$ \\
\hline Melbourne, Australia & 1 & 15 & 12 & 12 \\
\hline Sydney, Australia & 2 & 17 & 13 & 15 \\
\hline $\begin{array}{l}\text { Wellington, New } \\
\text { Zealand }\end{array}$ & 3 & 23 & 19 & 18 \\
\hline
\end{tabular}

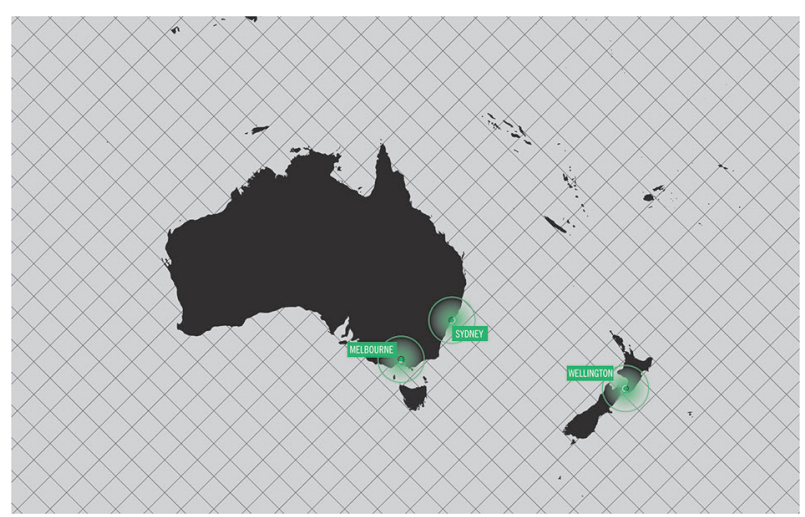

In Oceania, the ranking is led by Melbourne, which is also in the top 10 in dimensions such as social cohesion, governance and international outreach. Likewise, it is in the top 20 for the dimensions of human capital and urban planning. Sydney occupies second place in the regional ranking and stands out in the dimensions of technology and human capital. Completing the regional ranking is Wellington, which performs especially well in the environment, occupying second place. Likewise, this city is in the top 20 for the dimensions of social cohesion, urban planning, and mobility and transportation. 


\section{CASES}

This section describes some noteworthy cases. In Appendix 2 there is a graphical analysis of the 165 cities included in the CIMI.

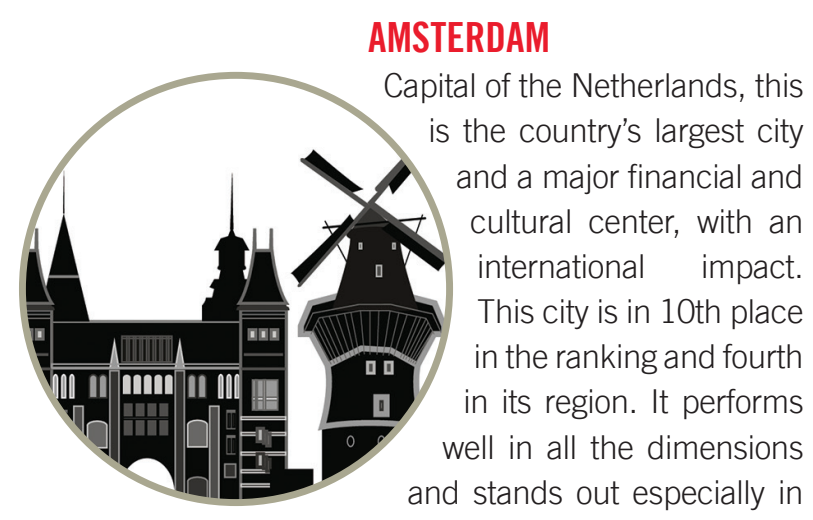
technology, urban planning and international outreach, being in the top 20 for all of those dimensions.

\section{BARCELONA}

This is the second best-placed Spanish city, in position 26, just one position behind Madrid. Barcelona performs well in almost every dimension, especially in governance, urban planning, international outreach, technology, and mobility and transportation, where it is in the top 20.

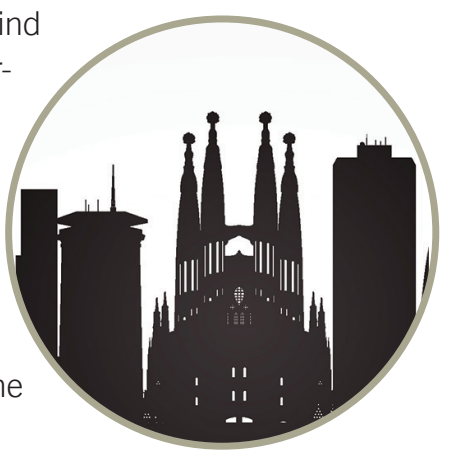

\section{BERN}

This is in position 29 in the ranking and is the best-placed Swiss city, ahead of Geneva. It is noteworthy for being first in the governance dimension and second for social cohesion. Bern was

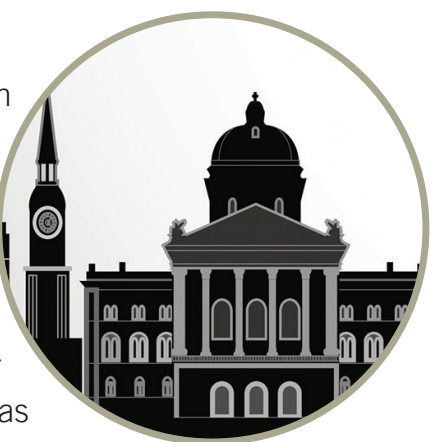
among the top 10 cities with

the best quality of life in the world in 2003, 2009 and 2011, according to the Mercer Quality of Living ranking.

\section{BERLIN}

This is in position 11 in the ranking, making it the best-placed German city. It is noteworthy for being

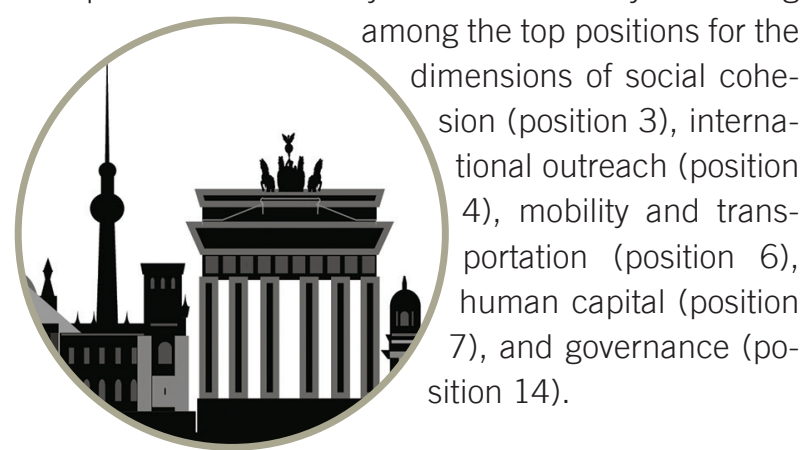

\section{BUENOS AIRES}

This is the capital and the most populous city of Argentina. It is the most-visited city in South America and has the second highest number of skyscrapers in the region. It is in position 76 in the overall ranking and number one in its region. It is the best-placed city in Latin America, ahead of Santiago de Chile and Panama City. It stands out, at the regional level, in the dimensions of governance, urban planning, and international outreach.

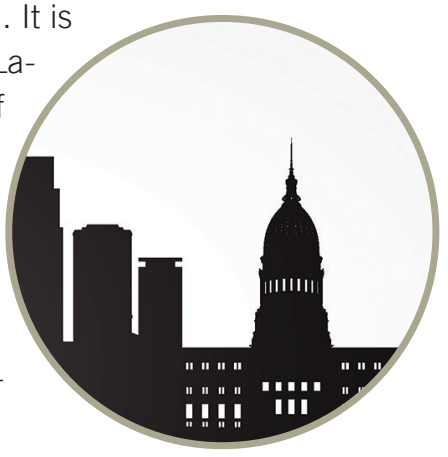




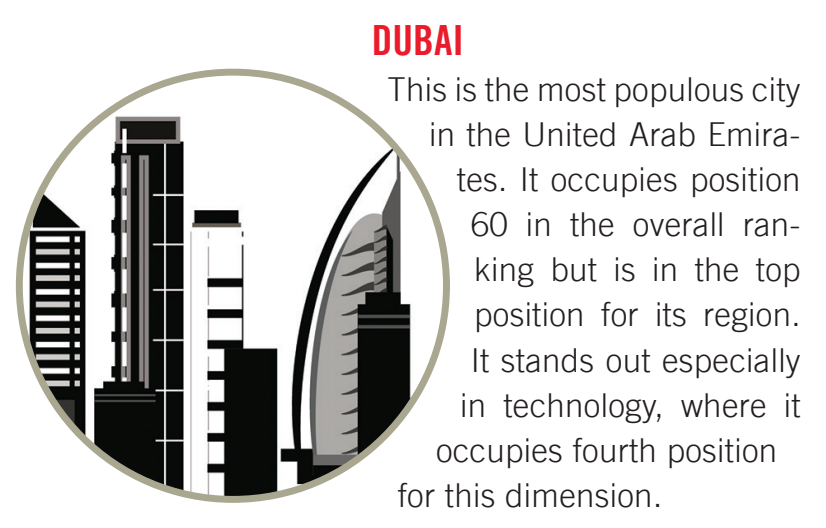

for this dimension.

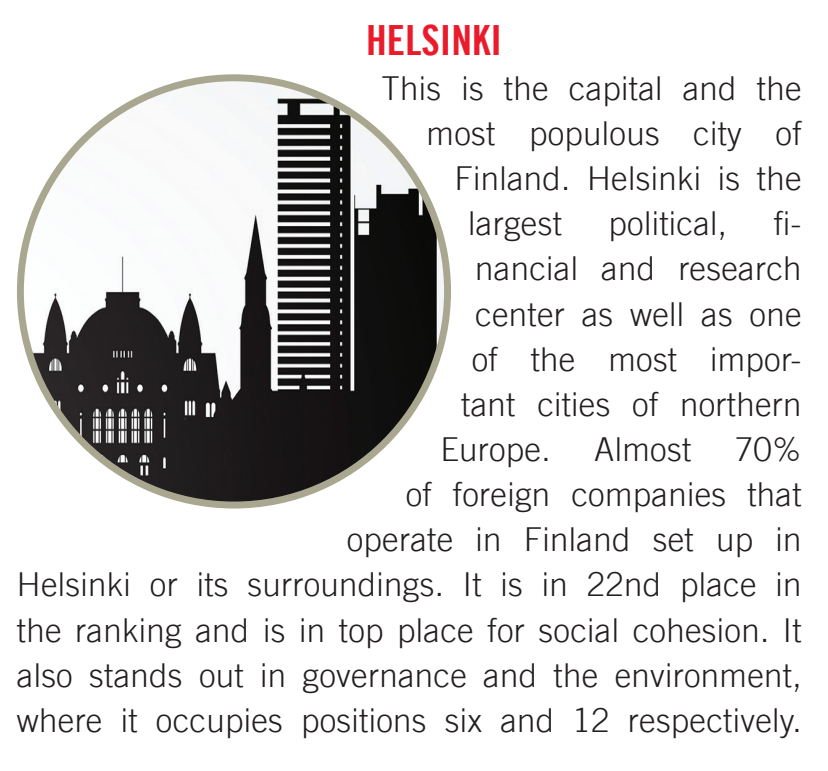

\section{HONG KONG}

Hong Kong is a special administrative region of the People's Republic of China, made up of a peninsula and several islands off the Chinese mainland's south coast, in the South China Sea. It is currently one of the most influential cities in Southeast Asia. It is in position 9 in the ranking, especially standing out in the technology dimension, where it occupies first place. It is also high up the ranking for the dimensions of human capital, urban planning and governance.

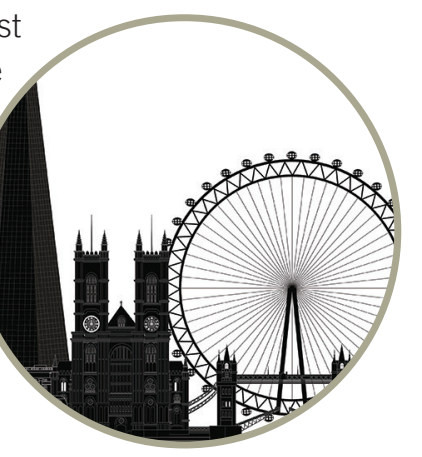

\section{LONDON}

This is the capital and most populous city of the United Kingdom and the largest urban area in the country. It is a nerve center in the field of the arts, commerce, education, entertainment, fashion, finance, the me-

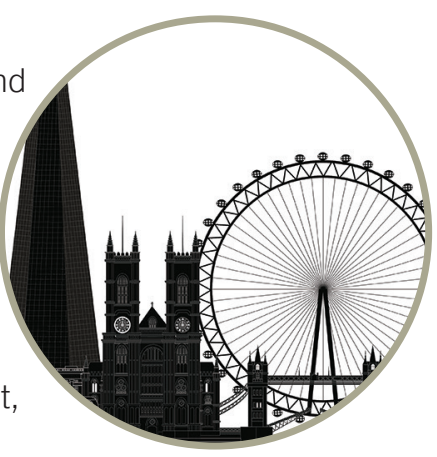
dia, research, tourism, and trans-

portation. For this reason, London is in second place in the ranking. It is a city well placed in almost all dimensions. It occupies first place for human capital and is in the top 10 for the dimensions of mobility and transportation, international outreach, the economy, governance, technology, and urban planning. Its worst performance can be seen in the dimension of social cohesion, where it occupies position 68.

\section{MADRID}

This is the capital and most populous city of

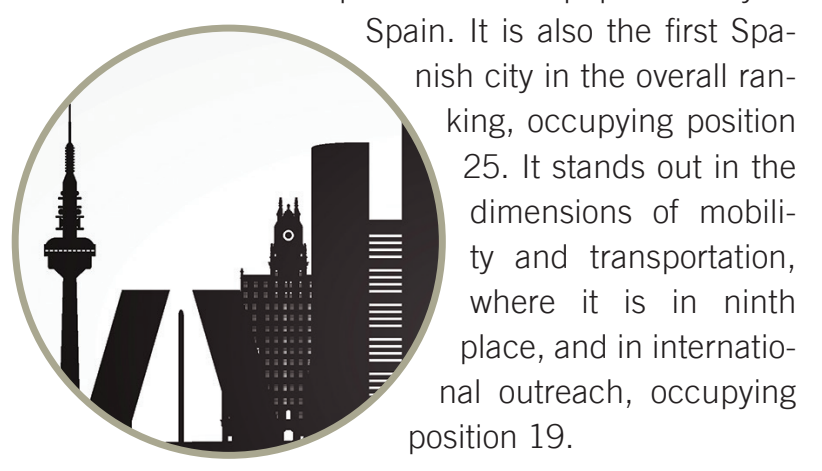

\section{MELBOURNE}

Melbourne is in 12th place in the overall ranking and is the top city in its region. It stands out in the dimensions of governance, in second place, and social cohesion, in eighth place. It is a city with low poverty and crime rates and high levels of health and education, both public and private. It is a city that shows a lot of homogeneity across all the dimensions of the CIMI, occupying good positions in almost all of them. 


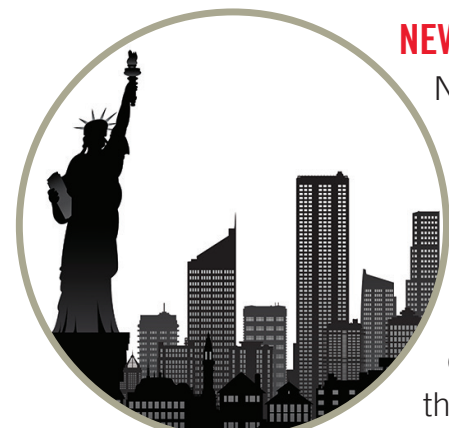

NEW YORK CITY

New York City is one of the three largest and most populous urban agglomerations in the world and is the second-largest urban concentration in Nor-

th America (after Mexico

City). For another year, New

York City

is in the top position in the ranking.

It is the world's most important economic center and is therefore ranked first in the economy dimension. It is one of the cities with the highest concentration of skyscrapers in the world and also has one of the largest collections of office buildings and residential towers in the world. For this reason, the city also occupies first place in urban planning. Likewise, it is in the top five for the dimensions of human capital, mobility and transportation, and international outreach.

\section{PARIS}

The French capital is the world's most popular tourist destination, as it welcomes more than 42 million foreign tourists a year. It is the most important financial center in Europe, hosting the headquarters of almost half of the largest French companies, as well as the headquarters of 20 of the 100 largest companies in the world. The city of Paris is, together with London, one of the most important financial hubs in Europe. This city is in third place in the overall ranking and is top in the dimensions of international outreach and of mobility and transportation. Likewise, it stands out in urban planning (position 3), the economy (position 7), and human capital (position 8).

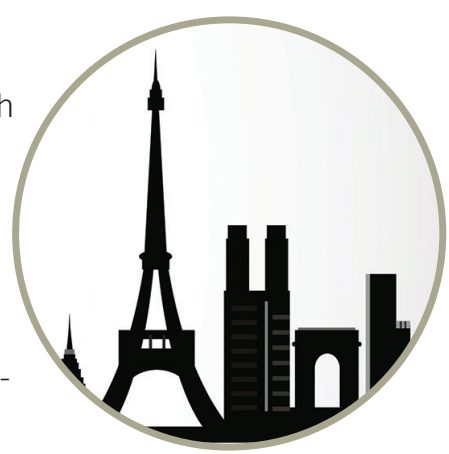

\section{PRAGUE}

The capital of the Czech Republic is the most populous city in the country and the seventh most populous in central Europe. This city leads the ranking in the eastern Europe region, while it occupies position 40 in the overall ranking. It is in the top 20 for the technology and international outreach dimensions.

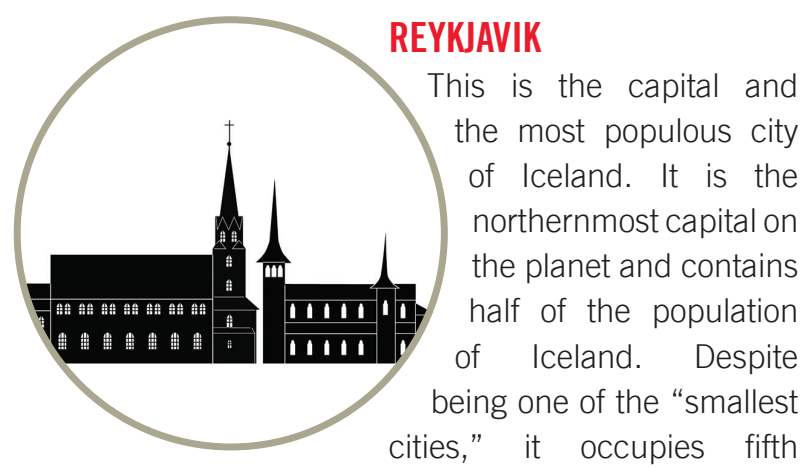

position in the overall ranking and leads the dimension of the environment. It stands out in technology and in mobility and transportation.

\section{TOKYO}

Tokyo is the capital of Japan and the most populous urban agglomeration in the world. It is one of the cities with the highest rate of labor productivity. It is fourth in the overall ranking, leading the Asian region. It stands out

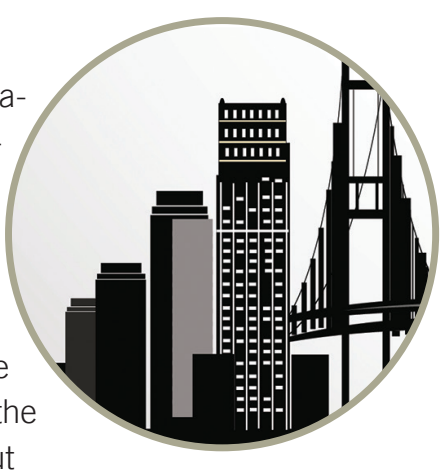
particularly in the economy dimension in position 2 and in the human capital dimension in position 5. In addition, it is in the top 30 for the dimensions of the environment, international outreach, mobility and transportation, and technology. 
TABLE 13. EVOLUTION OF THE INDEX FOR THE TOP 50 CITIES IN THE 2017 RANKING

\begin{tabular}{|c|c|c|c|c|c|}
\hline CITY & 2015 & 2016 & 2017 & $2015-2016$ & 2016-2017 \\
\hline New York-United States & 2 & 1 & 1 & 个 1 & $\Rightarrow 0$ \\
\hline London-United Kingdom & 1 & 2 & 2 & $\sqrt{-1}$ & $\Rightarrow 0$ \\
\hline Paris-France & 3 & 3 & 3 & $\Rightarrow 0$ & $\Rightarrow 0$ \\
\hline Tokyo-Japan & 4 & 4 & 4 & $\Rightarrow 0$ & $\Rightarrow 0$ \\
\hline Reykjavik-Iceland & 5 & 5 & 5 & $\Rightarrow 0$ & $\Rightarrow 0$ \\
\hline Singapore-Singapore & 6 & 6 & 6 & $\Rightarrow 0$ & $\Rightarrow 0$ \\
\hline Seoul-South Korea & 7 & 7 & 7 & $\Rightarrow 0$ & $\Rightarrow 0$ \\
\hline Toronto-Canada & 9 & 8 & 8 & ن 1 & $\Rightarrow 0$ \\
\hline Hong Kong-China & 8 & 9 & 9 & $\sqrt{b}-1$ & $\Rightarrow 0$ \\
\hline Amsterdam-Netherlands & 11 & 11 & 10 & $\Rightarrow 0$ & ن 1 \\
\hline Berlin-Germany & 10 & 10 & 11 & $\Rightarrow 0$ & $\sqrt{ }-1$ \\
\hline Melbourne-Australia & 15 & 12 & 12 & ن 3 & $\Rightarrow 0$ \\
\hline Copenhagen-Denmark & 16 & 16 & 13 & $\Rightarrow 0$ & ن 3 \\
\hline Chicago-United States & 13 & 14 & 14 & $\S-1$ & $\Rightarrow 0$ \\
\hline Sydney-Australia & 17 & 13 & 15 & 个 4 & $\sqrt{b}-2$ \\
\hline Stockholm-Sweden & 18 & 18 & 16 & $\Rightarrow 0$ & 个 2 \\
\hline Los Angeles-United States & 14 & 15 & 17 & $\sqrt{-1}$ & $\sqrt{-2}$ \\
\hline Wellington-New Zealand & 23 & 19 & 18 & ن 4 & ن 1 \\
\hline Vienna-Austria & 20 & 20 & 19 & $\Rightarrow 0$ & 个 1 \\
\hline Washington-United States & 21 & 17 & 20 & 个 4 & $\sqrt{b}-3$ \\
\hline Boston-United States & 19 & 22 & 21 & $\sqrt{5}-3$ & ㄴ 1 \\
\hline Helsinki-Finland & 31 & 30 & 22 & ㄴ 1 & ن 8 \\
\hline Oslo-Norway & 12 & 24 & 23 & $\sqrt{-12}$ & ㄴ 1 \\
\hline Zurich-Switzerland & 22 & 23 & 24 & $\sqrt{ }-1$ & $\sqrt{ }-1$ \\
\hline Madrid-Spain & 29 & 26 & 25 & ن 3 & ㄴ 1 \\
\hline Barcelona-Spain & 34 & 29 & 26 & ㄴ 5 & ن 3 \\
\hline San Francisco-United States & 24 & 25 & 27 & $\checkmark-1$ & $\checkmark-2$ \\
\hline Auckland-New Zealand & 25 & 31 & 28 & $\sqrt{b}-6$ & i 3 \\
\hline Bern-Switzerland & 26 & 27 & 29 & $\sqrt{-1}$ & $\sqrt{b}-2$ \\
\hline Dublin-Ireland & 33 & 21 & 30 & 个 12 & $\sqrt{-9}$ \\
\hline Hamburg-Germany & 37 & 33 & 31 & 个 4 & 个 2 \\
\hline Geneva-Switzerland & 27 & 32 & 32 & $\sqrt{ }-5$ & $\Rightarrow 0$ \\
\hline Göteborg-Sweden & 36 & 39 & 33 & $\sqrt{5}-3$ & ㄴ 6 \\
\hline Basel-Switzerland & 38 & 36 & 34 & ㄴ 2 & ㄴ 2 \\
\hline Ottawa-Canada & 35 & 37 & 35 & $\sqrt{ }-2$ & i 2 \\
\hline Vancouver-Canada & 30 & 28 & 36 & i 2 & $\sqrt{3}-8$ \\
\hline Munich-Germany & 28 & 35 & 37 & $\sqrt{5}-7$ & $\sqrt{-2}$ \\
\hline Montreal-Canada & 39 & 38 & 38 & ن 1 & $\Rightarrow 0$ \\
\hline Houston-United States & 32 & 34 & 39 & $\sqrt{b}-2$ & $\checkmark-5$ \\
\hline Prague-Czech Republic & 43 & 40 & 40 & i 3 & $\Rightarrow 0$ \\
\hline Dallas-United States & 42 & 44 & 41 & $\sqrt{ }-2$ & ن 3 \\
\hline Frankfurt-Germany & 47 & 45 & 42 & ㄴ 2 & ㄴ 3 \\
\hline Rotterdam-Netherlands & 46 & 43 & 43 & 个 3 & $\Rightarrow 0$ \\
\hline Lyon-France & 48 & 46 & 44 & ㄴ 2 & 个 2 \\
\hline Milan-Italy & 58 & 49 & 45 & 个 9 & 个 4 \\
\hline Philadelphia-United States & 41 & 41 & 46 & $\Rightarrow 0$ & $\sqrt{-5}$ \\
\hline San Diego-United States & 49 & 50 & 47 & $\checkmark-1$ & i 3 \\
\hline Brussels-Belgium & 44 & 47 & 48 & $\sqrt{ }-3$ & $\checkmark-1$ \\
\hline Riga-Latvia & 45 & 48 & 49 & $\sqrt{ }-3$ & $\checkmark-1$ \\
\hline Tallinn-Estonia & 40 & 42 & 50 & $\sqrt{b}-2$ & $\sqrt{-8}$ \\
\hline
\end{tabular}


Figure 3 below shows the positions in 2015 and 2017 of the top 50 cities in the ranking. Those cities that show a positive evolution are below the 45-degree angle formed by the diagonal line, while the cities whose evolution was not positive are above that line. For example,
Tallinn, as mentioned previously, displays a clear negative evolution, since it dropped from position 40 in 2015 to position 50 in 2017. In contrast, Milan shows a positive evolution, rising from position 58 to 45 in 2017.

FIGURE 3

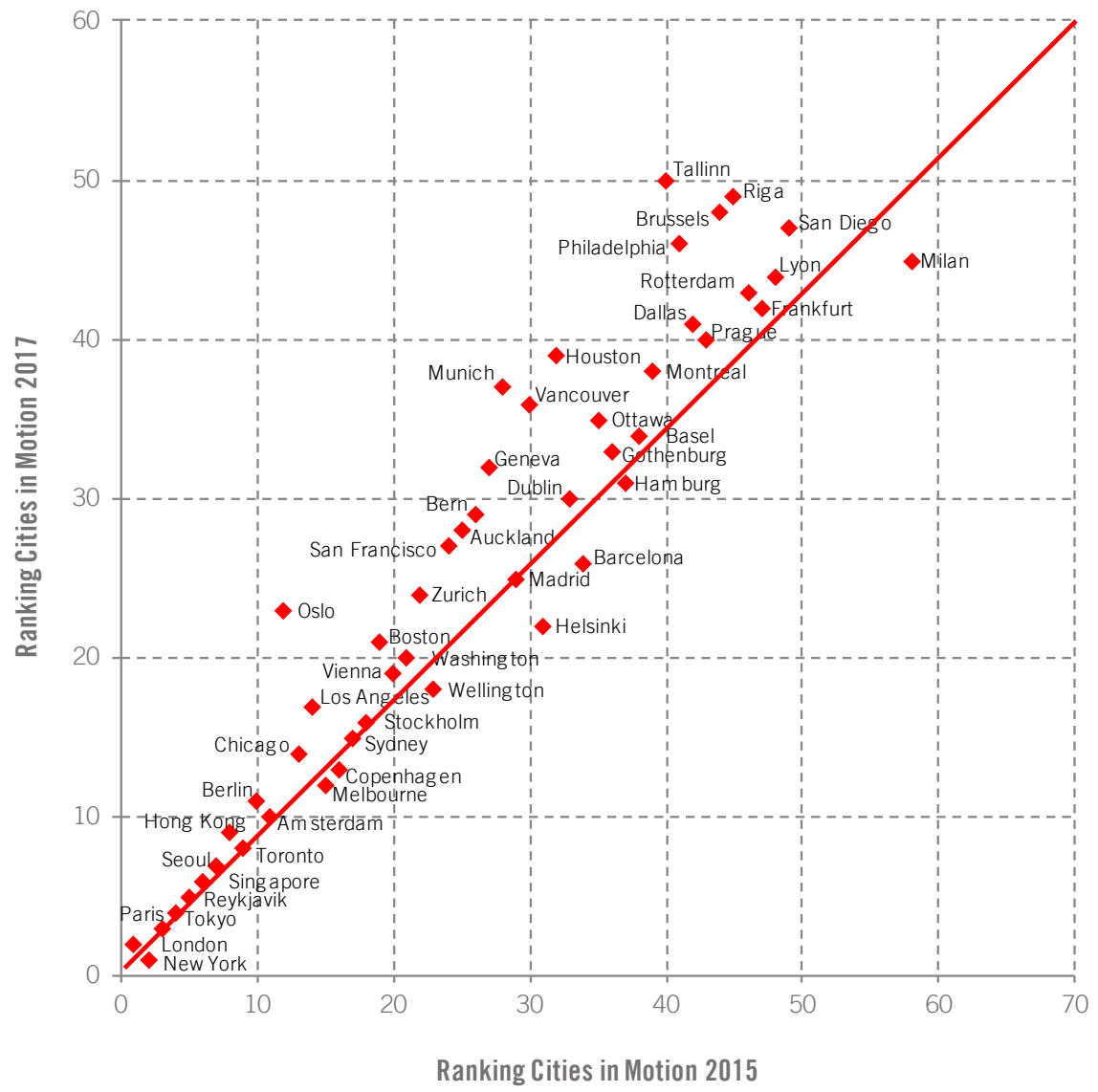




\section{CITIES IN MOTION COMPARED WITH OTHER INDEXES}

In this section we conduct a comparative study of the CIMI and other indexes. Table 14 shows the top $10 \mathrm{ci}$ ties in the CIMI 2017 ranking compared with those in seven other city indexes under consideration. Cities in those indexes are highlighted when they also appear in the CIMI.

While the indexes under consideration vary in terms of methodology and indicators, all agree that a city is more powerful, prosperous, and competitive if it manages to develop in its various dimensions, from the economy and finance, via the ease of creating businesses, the quality of life, and the use of high technology, to its cultural importance, which could be measured by how it promotes music and fashion. It can be noted that all of the cities in the CIMI frequently appear in some of the other indexes under consideration, with the exception of Reykjavik.

The city of Singapore, which occupies position 6 in the CIMI, is in the top 10 of five of the seven other rankings being considered. This city stands out for its high performance in the dimensions of technology, international outreach, the environment and the economy.
The city of Hong Kong, which is ranked ninth in the CIMI, occupies the leading positions of four of the seven rankings analyzed. As could be verified through the CIMI, this city performs very well in technology, where it occupies the top spot. It also occupies leading positions in urban planning, human capital, governance, and international outreach.

The cities of New York, London, Paris, Tokyo, Seoul and Toronto also appear frequently in other rankings among the 10 most prosperous cities or those with the best quality of life in the world. The only city that does not appear among the top 10 cities considered by other indexes is Reykjavik. This city is often excluded from some rankings that take into account only large cities. Unlike many of the rankings with which it is compared, the CIMI takes into account a greater geographical coverage.

None of the cities that make up the top 10 of the CIMI are in the top positions of the Quality of Living Ranking (Mercer). However, both Vienna and Copenhagen are in the CIMI top 20. It is interesting to note that the top four positions in the Global Cities Index (A.T. Kearney) and the Global Power City Index (Mori Memorial Foundation) coincide exactly with the top four positions in the CIMI.

TABLE 14. COMPARISON WITH OTHER INDEXES. TOP 10

\begin{tabular}{|c|c|c|c|c|c|c|c|c|}
\hline $\begin{array}{c}\text { Ranking } \\
\text { City }\end{array}$ & $\begin{array}{l}\text { ICIM } 2017 \\
\text { (IESE) }\end{array}$ & $\begin{array}{l}\text { Global Cities } \\
\text { Index } 2016 \\
\text { (A.T. Kearney) }\end{array}$ & $\begin{array}{l}\text { Global Financial } \\
\text { Centres } \\
\text { Index 2017, GFCI } \\
\text { (Z/Yen) }\end{array}$ & $\begin{array}{l}\text { Global Power } \\
\text { City } \\
\text { Index } 2017 \\
\text { (MMF) }\end{array}$ & $\begin{array}{l}\text { Quality of } \\
\text { Living City } \\
\text { Ranking } 2017 \\
\text { (Mercer) }\end{array}$ & $\begin{array}{l}\text { Global Liveability } \\
\text { Ranking } 2017 \\
\text { (The Economist } \\
\text { Intelligence Unit) }\end{array}$ & $\begin{array}{c}\text { The Safe } \\
\text { Cities } \\
\text { Index } 2017 \\
\text { (The Economist) }\end{array}$ & $\begin{array}{l}\text { Sustainable } \\
\text { Cities } \\
\text { Index } 2016 \\
\text { (Acardis) }\end{array}$ \\
\hline 1 & New York & New York & London & London & Vienna & Melbourne & Tokyo & Zurich \\
\hline 2 & London & London & New York & New York & Zurich & Vienna & Singapore & Singapore \\
\hline 3 & Paris & Paris & Hong Kong & Tokyo & Auckland & Vancouver & Osaka & Stockholm \\
\hline 4 & Tokyo & Tokyo & Singapore & Paris & Munich & Toronto & Toronto & Vienna \\
\hline 5 & Reykjavik & Hong Kong & Tokyo & Singapore & Vancouver & Calgary & Melbourne & London \\
\hline 6 & Singapore & Singapore & Shanghai & Seoul & Dusseldorf & Adelaide & Amsterdam & Frankfurt \\
\hline 7 & Seoul & Chicago & Toronto & Amsterdam & Frankfurt & Perth & Sydney & Seoul \\
\hline 8 & Toronto & Los Angeles & Sydney & Berlin & Geneva & Auckland & Stockholm & Hamburg \\
\hline 9 & Hong Kong & Beijing & Zurich & Hong Kong & Copenhaguen & Helsinki & Hong Kong & Prague \\
\hline 10 & Amsterdam & Washington & Beijing & Sydney & Basel & Hamburg & Zurich & Munich \\
\hline
\end{tabular}




\section{CITIES IN MOTION: CITY RANKING BY POPULATION}

This section presents a ranking of cities according to their population. To obtain this ranking, the 165 cities of the index were classified according to their population. The cities were grouped by taking into account various sources such as The Economist and the United Nations. Table 15 shows the various categories and the number of CIMI cities included in each.

\section{TABLE 15 CLASSIFICATION OF CITIES ACCORDING TO THEIR POPULATION}

\begin{tabular}{llc} 
& CATEGORY & NUMBER OF CITIES \\
\hline Smallest cities & Fewer than 600,000 & 14 \\
\hline Small cities & Between 600,000 and 1 million & 12 \\
\hline Medium cities & Between 1 million and 5 million & 88 \\
\hline Large cities & Between 5 million and 10 million & 22 \\
\hline Megacities & More than 10 million & 29 \\
\hline
\end{tabular}

\section{RANKING OF THE "SMALLEST CITIES"}

The top five so-called "smallest cities" are headed by Reykjavik, which comes fifth in the overall ranking and third in the Western Europe region. This city stands out in many dimensions despite its size - except in the international outreach dimension, where it occupies position 121. In second place in the ranking of the "smallest cities" is Wellington. This city, together with Reykjavik, also leads the ranking of the environment dimension. The top five are completed by three Swiss cities: Bern, Geneva and Basel, which stand out for their performance in the governance dimension.

\section{TOP 5 CITIES WITH FEWER THAN 600,000 INHABITANTS}

\begin{tabular}{|l|cccc}
\hline \multicolumn{1}{|c}{ CIIY } & $\begin{array}{c}\text { POSITION BY } \\
\text { SIZE }\end{array}$ & $\begin{array}{c}\text { GLOBAL POSITION } \\
\text { RII }\end{array}$ & $\begin{array}{c}\text { GLOBAL POSITION } \\
2016\end{array}$ & $\begin{array}{c}\text { GLOBAL POSITION } \\
2017\end{array}$ \\
\hline Reykjavik, Iceland & 1 & 5 & 5 & 5 \\
\hline Wellington, New Zealand & 2 & 23 & 19 & 18 \\
\hline Bern, Switzerland & 3 & 26 & 27 & 29 \\
\hline Geneva, Switzerland & 4 & 27 & 32 & 32 \\
\hline Basel, Switzerland & 5 & 38 & 36 & 34 \\
\hline
\end{tabular}




\section{RANKING OF THE "SMALL CITIES"}

The following table shows the top five "small cities," or cities that have a population of between 600,000 and 1 million inhabitants. This ranking is led by Göteborg, followed by Riga. The cities of Vilnius, Bratislava and Nice complete the ranking. Despite not being in the top positions of the overall ranking, these cities stand out - as do the "smallest cities" - for their performance in the environment dimension. All, except for Nice, are in the top 30 for that dimension.

TOP 5 CITIES BETWEEN 600,000 AND 1 MILLION INHABITANTS

\begin{tabular}{lcccc}
\hline \multicolumn{1}{|c}{ CITY } & $\begin{array}{c}\text { POSITION BY } \\
\text { SIZE }\end{array}$ & $\begin{array}{c}\text { GLOBAL POSITION } \\
2015\end{array}$ & $\begin{array}{c}\text { GLOBAL POSITION } \\
2016\end{array}$ & $\begin{array}{c}\text { GLOBAL POSITION } \\
2017\end{array}$ \\
\hline Göteborg, Sweden & 1 & 36 & 39 & 33 \\
\hline Riga, Latvia & 2 & 45 & 48 & 49 \\
\hline Vilnius, Lithuania & 3 & 59 & 56 & 61 \\
\hline Bratislava, Slovakia & 4 & 60 & 65 & 67 \\
\hline Nice, France & 5 & 81 & 80 & 79 \\
\hline
\end{tabular}

\section{RANKING OF THE "MEDIUM CITIES"}

Below are the top five "medium cities" - that is, cities that have between 1 million and 5 million inhabitants. This ranking is led by Amsterdam, followed by Melbourne, Copenhagen, Sydney and Stockholm. These cities are in the top 20 positions of the overall ranking and stand out in almost every dimension.

\section{TOP 5 CITIES WITH BETWEEN 1 MILLION AND 5 MILLION INHABITANTS}

\begin{tabular}{|c|c|c|c|c|}
\hline CITY & $\begin{array}{l}\text { POSITION BY } \\
\text { SIZE }\end{array}$ & $\begin{array}{l}\text { GLOBAL POSITION } \\
2015\end{array}$ & $\begin{array}{l}\text { GLOBAL POSITION } \\
2016\end{array}$ & $\begin{array}{l}\text { GLOBAL POSITION } \\
2017\end{array}$ \\
\hline Amsterdam, Netherlands & 1 & 11 & 11 & 10 \\
\hline Melbourne, Australia & 2 & 15 & 12 & 12 \\
\hline Copenhagen, Denmark & 3 & 16 & 16 & 13 \\
\hline Sydney, Australia & 4 & 17 & 13 & 15 \\
\hline Stockholm, Sweden & 5 & 18 & 18 & 16 \\
\hline
\end{tabular}




\section{RANKING OF THE “LARGE CITIES”}

The following shows the ranking of the "large cities" or cities that have between 5 million and 10 million inhabitants. This ranking is led by Singapore, followed by Toronto and Hong Kong. The cities of Berlin and Chicago complete the ranking for this dimension.

\section{TOP 5 CITIES WITH BETWEEN 5 MILLION AND 10 MILLION INHABITANTS}

\begin{tabular}{|c|c|c|c|c|}
\hline CITY & $\begin{array}{l}\text { POSITION BY } \\
\text { SIZE }\end{array}$ & $\begin{array}{l}\text { GLOBAL POSITION } \\
2015\end{array}$ & $\begin{array}{l}\text { GLOBAL POSITION } \\
2016\end{array}$ & $\begin{array}{l}\text { GLOBAL POSITION } \\
2017\end{array}$ \\
\hline Singapore, Singapore & 1 & 6 & 6 & 6 \\
\hline Toronto, Canada & 2 & 9 & 8 & 8 \\
\hline Hong Kong, China & 3 & 8 & 9 & 9 \\
\hline Berlin, Germany & 4 & 10 & 10 & 11 \\
\hline Chicago, United States & 5 & 13 & 14 & 14 \\
\hline
\end{tabular}

\section{RANKING OF THE "MEGACITIES"}

The ranking of the "megacities" includes cities with a population of more than 10 million inhabitants. It is headed by New York, followed by London, Paris, Tokyo and Seoul. These cities occupy the tops positions of the overall ranking and stand out in almost all the dimensions, with the exception of social cohesion and the environment.

TOP 5 CITIES WITH MORE THAN 10 MILLION INHABITANTS

\begin{tabular}{|c|c|c|c|c|}
\hline CITY & $\begin{array}{l}\text { POSITION BY } \\
\text { SIZE }\end{array}$ & $\begin{array}{c}\text { GLOBAL POSITION } \\
2015\end{array}$ & $\begin{array}{c}\text { GLOBAL POSITION } \\
2016\end{array}$ & $\begin{array}{c}\text { GLOBAL POSITION } \\
2017\end{array}$ \\
\hline New York City, United States & 1 & 2 & 1 & 1 \\
\hline London, United Kingdom & 2 & 1 & 2 & 2 \\
\hline Paris, France & 3 & 3 & 3 & 3 \\
\hline Tokyo, Japan & 4 & 4 & 4 & 4 \\
\hline Seoul, South Korea & 5 & 7 & 7 & 7 \\
\hline
\end{tabular}




\section{CITIES IN MOTION: \\ ANALYSIS OF \\ DIMENSIONS IN \\ PAIRS}

In this section, the position of cities with respect to two dimensions is analyzed simultaneously. In this way, it is possible to observe whether there is any relationship between the dimensions being compared. Furthermore, cities are analyzed by population, according to the categories discussed in the previous section.

Figure 4 shows the dimensions of the economy on the $y$-axis and social cohesion on the x-axis. The "smallest cities" perform well in the dimension of social cohesion, as can be seen by their position on the right of the graph. Similarly, many of these cities also perform well in the economy dimension. A large number of "megacities," on the other hand, show relatively good perfor- mance in the economy dimension but, in general, very poor performance in the dimension of social cohesion. In the so-called "small," "medium" and "large" cities, there is a direct relationship between both dimensions. As a city improves its performance in the dimension of the economy, it also does so in the dimension of social cohesion. It can also be seen that the Chinese cities such as Hong Kong, Shenzhen, Beijing and Shanghai - are grouped in the upper left of the graph, indicating good performance in the economy and poor performance in social cohesion.

\section{FIGURE 4}

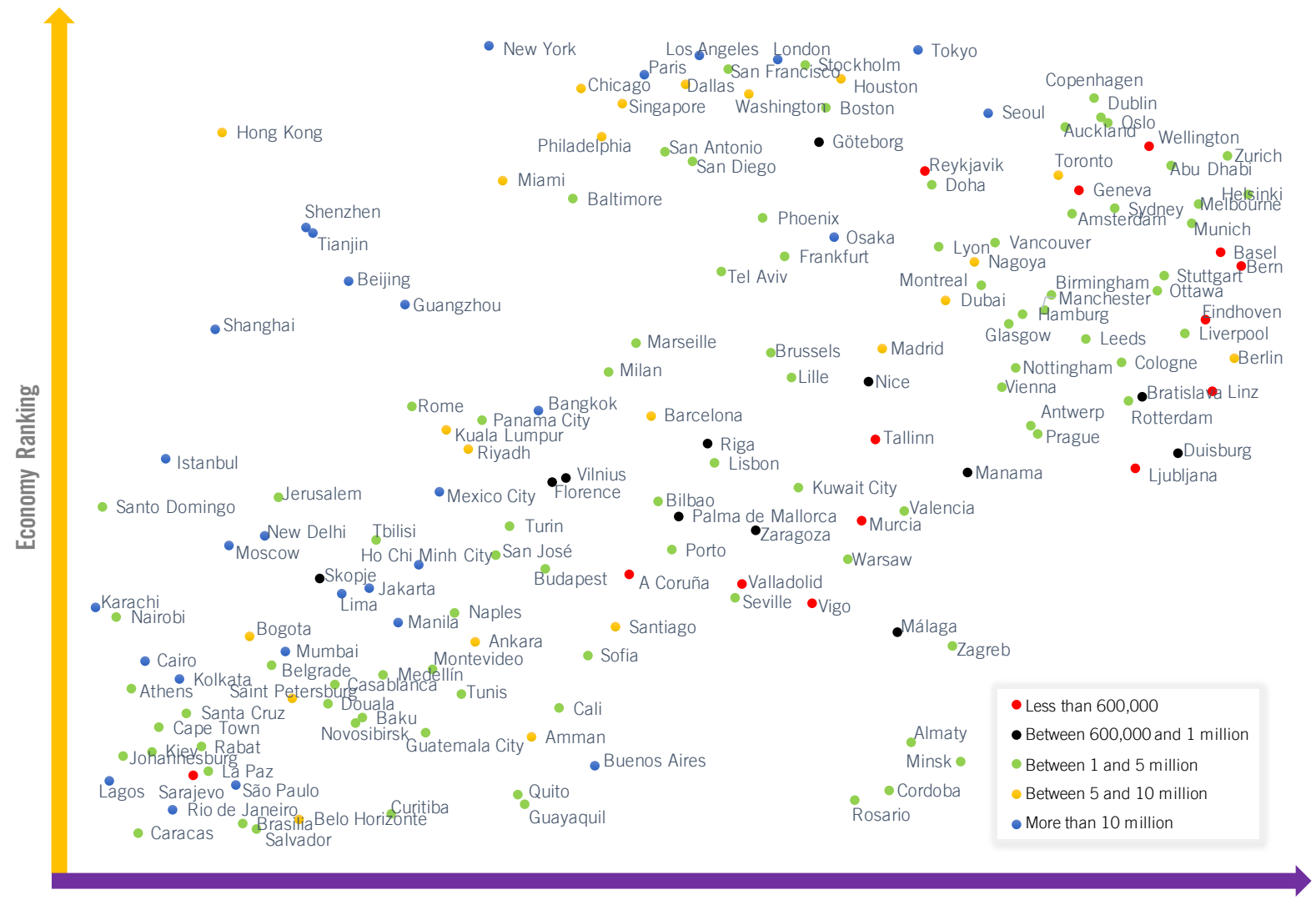


Figure 5 analyzes the dimensions of the economy and the environment. The dimension of the economy is shown on the $y$-axis and the environment on the $x$-axis. The Chinese and U.S. cities are found in the upper left of the graph. These cities stand out because they perform well in the area of the economy but poorly in the environment. This could lead to the conclusion that a high level of economic development is detrimental to the well-being of the environment. The cities in the upper right show good performance in both the economy and the environment. This group includes a large number of European cities, such as Stockholm, Copenhagen, Oslo, Göteborg, Reykjavik and Zurich, as well as Asian cities such as Tokyo and Seoul and some from Oceania such as Wellington, Auckland and Sydney. Some of the "smallest cities," such as Reykjavikand Wellington, also stand out in this group. In the lower left corner, there are cities with a poor performance in both dimensions, such as Lagos, Jakarta, Cairo and Johannesburg. Finally, the lower right-hand side shows the cities with low economic development but a good performance in the environment. In this group we find the cities of Vigo, Zagreb, Belgrade, Buenos Aires and Montevideo, among others. A conclusion could be drawn that a high degree of economic development is often related to poor performance in the environmental field if cities do not take ecological criteria into account during that development.

\section{FIGURE 5}

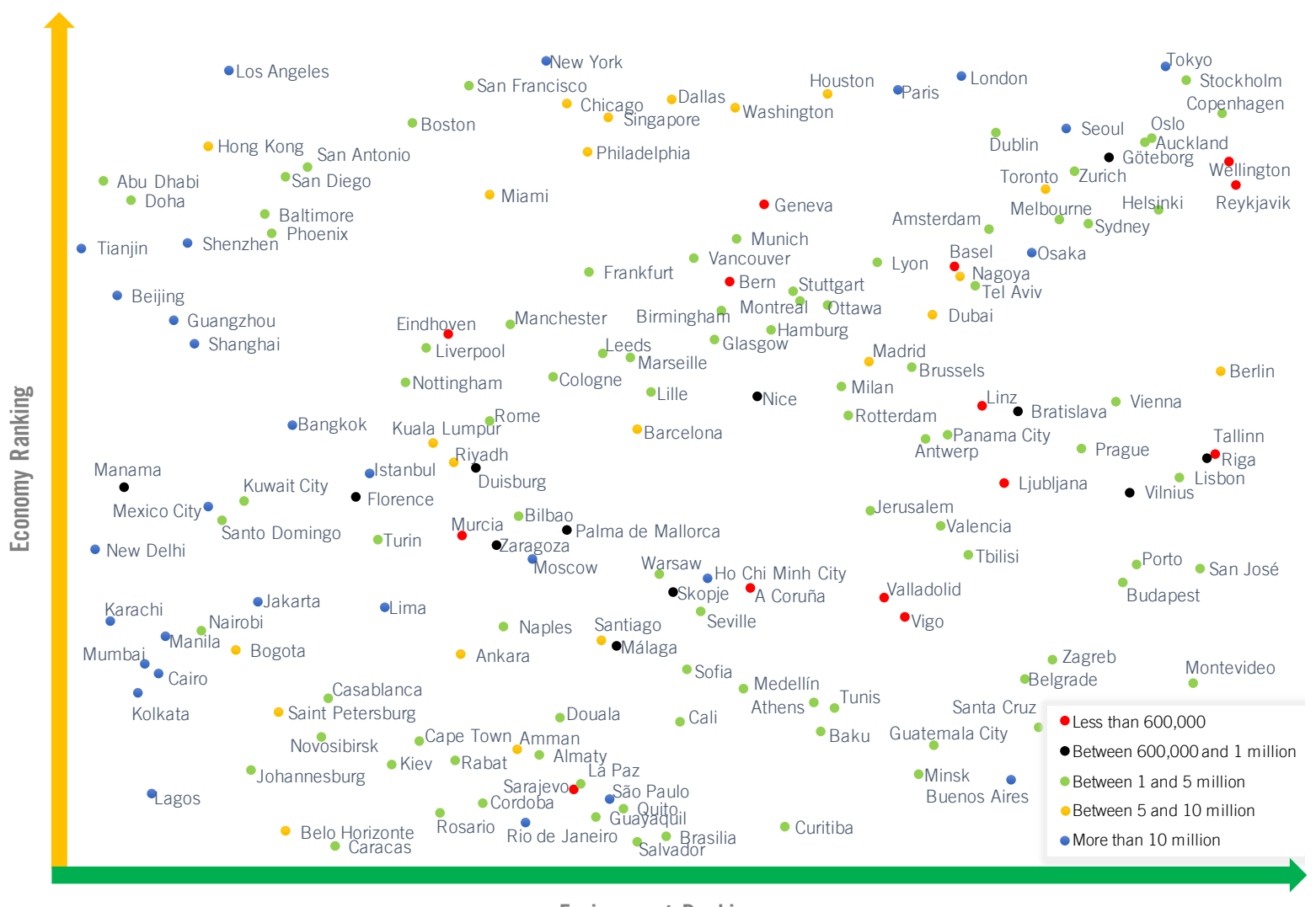

Environment Ranking 
Figure 6 shows the dimensions of mobility and transportation and the environment. Here we see at the top of the graph that the "smallest" and "small" cities perform well in mobility and transportation. Some of them also demonstrate good performance in the environment, as is the case with Reykjavik and Wellington. The upper left of the graph shows cities that perform well in mobility and transportation but poorly in the environment dimension. Here we find the Chinese "megacities" and some North American ones such as Phoenix. The upper right-hand side shows the cities that perform well in both dimensions. The smallest cities - such as Basel, Reykjavik, Wellington, Geneva and Bern - are mostly located here. The lower left shows the cities with low degrees of development in mobility and transportation and also in the environment. This group includes cities such as Bogotá, Manila, Mumbai, New Delhi and Kolkata. Finally, the lower right-hand side shows the cities that have a high degree of environmental development but a poor performance in mobility and transportation. In this group we find cities from Central and South America, such as Montevideo, Santa Cruz, San José and Guatemala, as well as cities in the Middle East, such as Jerusalem and Tel Aviv.

\section{FIGURE 6}

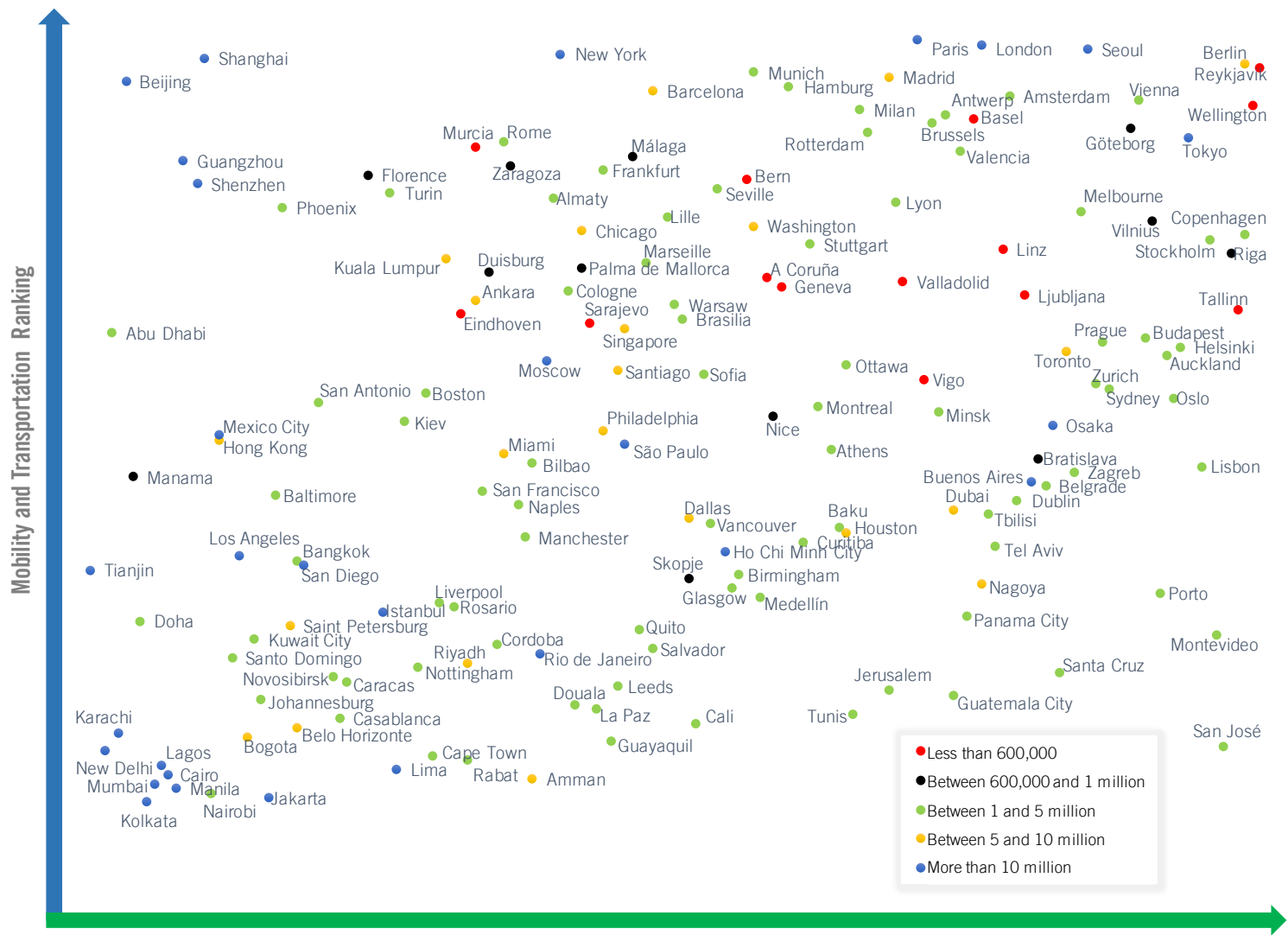

Environment Ranking 


\section{CITIES IN MOTION: A DYNAMIC ANALYSIS}

To assess the growth trends and potential of the different cities, we have created a graph that seeks to capture these aspects. Figure 7 sets out the current position of each of the cities in the CIMI index (x-axis) and the trend (y-axis). As a measure to calculate the trend, the change in terms of number of positions the cities in the CIMI ranking experienced between 2015 and 2017 has been used. This means that the cities in the top part of the graph are those that have improved in position while those in the bottom part of the graph have dropped position. Consequently, the center of the graph shows the cities that have not experienced significant changes in their position in the years analyzed.

The graph area has been divided into four quadrants according to the type of city (consolidated, challenger, potential, and vulnerable).

The first group, that of consolidated cities (bottom right quadrant), includes cities that, although they have a middle to high overall position, have not experienced any changes throughout the period or may have even lost a few positions. It is made up of cities from different geographical regions: Houston, Philadelphia, Vancouver, Los Angeles, San Francisco, Boston and Chicago in North America; London, Glasgow, Munich, Oslo, Geneva, Bern, Zurich and Oslo in Europe; Auckland in Oceania; and Hong Kong in Asia.

The challenger cities make up the second group displayed in the graph (top right quadrant). It is made up of cities that have improved their positions in the index at a fast rate and are already in the middle to high area of the classification. In this quadrant we can find cities such as Milan, Barcelona, Helsinki and Frankfurt.

The third group is made up of cities that have great potential and that, despite their current position in the middle to low area of the index, are evolving positively at great speed (top left quadrant). In this quadrant, we can find cities such as Kiev, Bilbao and A Coruña; Latin American capitals such as San Salvador and Guatemala City; and Asian cities such as Jakarta, Manila and Ho Chi Minh City.

The last group of cities includes those that are in a vulnerable position (bottom left quadrant). This is a group that is growing at a slower pace than the rest and is in the middle to low position of the classification. It is made up of cities such as Sarajevo, Quito and Rio de Janeiro.

The information presented in Figure 7 is complemented by an analysis of variance of the dimensions concerning the cities. That is, the aim is to understand not only how

\section{FIGURE 7}

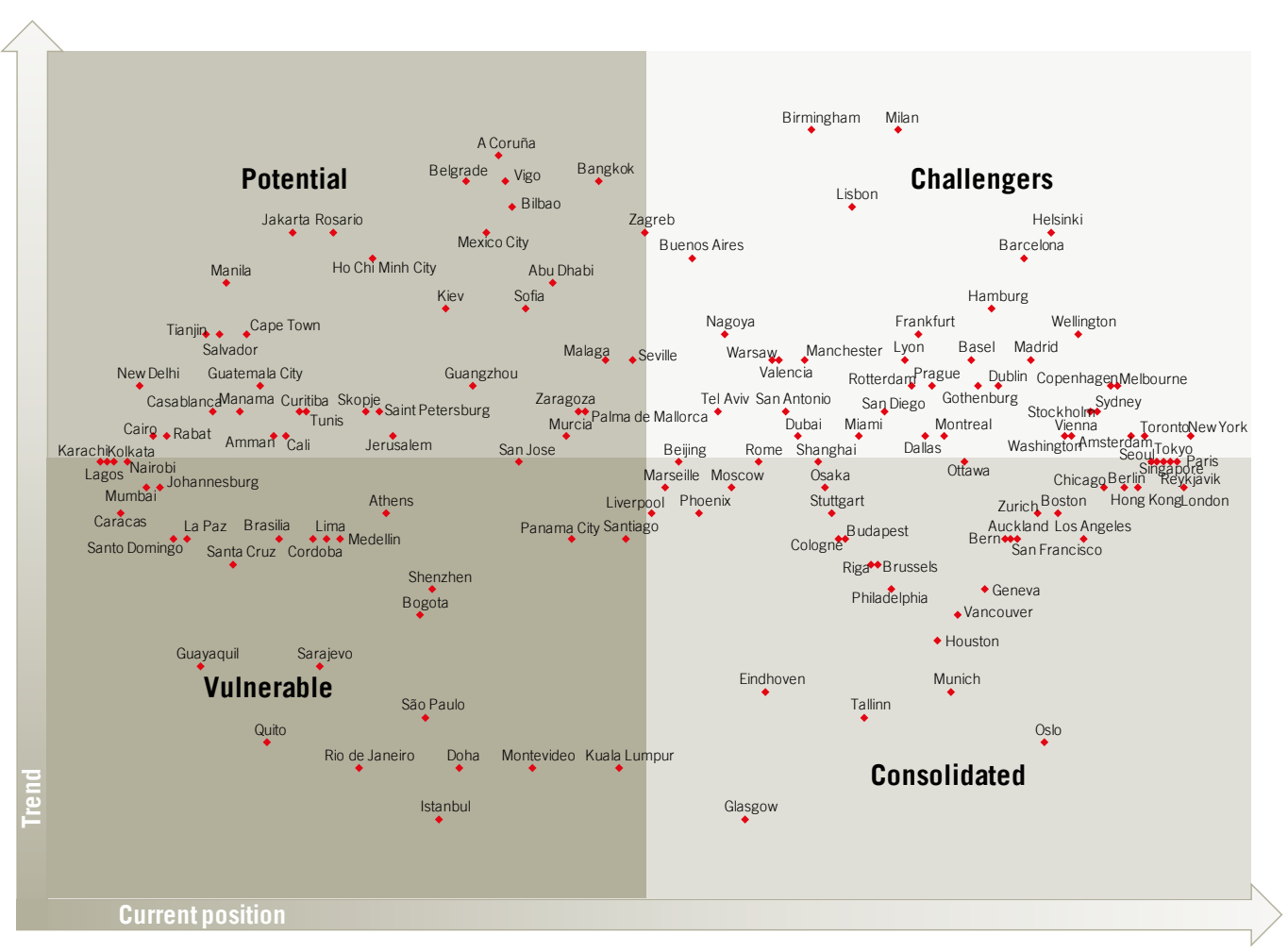


much they have grown but also how they have done so. To do this, the variation of the different dimensions was calculated for each of the cities that are set out in Figure 8 . The cities at the bottom of the graph have similar positions in all dimensions and therefore show a more homogeneous distribution. However, the cities in the top stand out in one or several dimensions while in others they are in a relatively low position. This information, combined with the position of each city, allows us to identify four categories of cities.

The first category is made up of "balanced" cities (bottom right quadrant) - that is, those that are in the upper middle part of the table and have relatively high values in all the dimensions. This category includes cities such as Stockholm, Brussels, Madrid, Amsterdam, Hamburg, Toronto, Melbourne, Tokyo, Seoul and Sydney.

The second category consists of the "differentiated" cities (top right quadrant) - that is, those cities that are in high positions in the ranking and that get exceptional results in several dimensions but relatively poor ones in others. An example is New York City, which is among the top positions in seven of the nine dimensions but among the lowest positions in social cohesion and the environment. Another example is Los Angeles, which ranks among the top positions in the economy, human capital and governance but in the lowest positions for the environment and for mobility and transportation. In this category we also find cities such as Hong Kong, Shanghai, Houston and Bern.

The third quadrant (top left quadrant) corresponds to the so-called "unbalanced" cities - that is, cities that are in the bottom positions of the ranking but stand out in one dimension in particular. This includes, for example, the cities of Doha, Istanbul and Montevideo, which stand out in a particular dimension despite being below position 100 in most of the dimensions. The city of Montevideo stands out in the environment (position 7), Doha stands out in technology (position 11) and Istanbul stands out in international outreach (position 18). In this category we also find cities such as Manama, Shenzhen, Athens, Rio de Janeiro and Rosario.

In the fourth and final quadrant (bottom left quadrant) are the so-called "stagnant" cities, which achieve poor results in (almost) all the dimensions analyzed. An example is the city of Skopje, which is below position 100 in seven of the nine dimensions. In this category we also find cities such as Lagos, Kolkata and Nairobi.

\section{FIGURE 8}

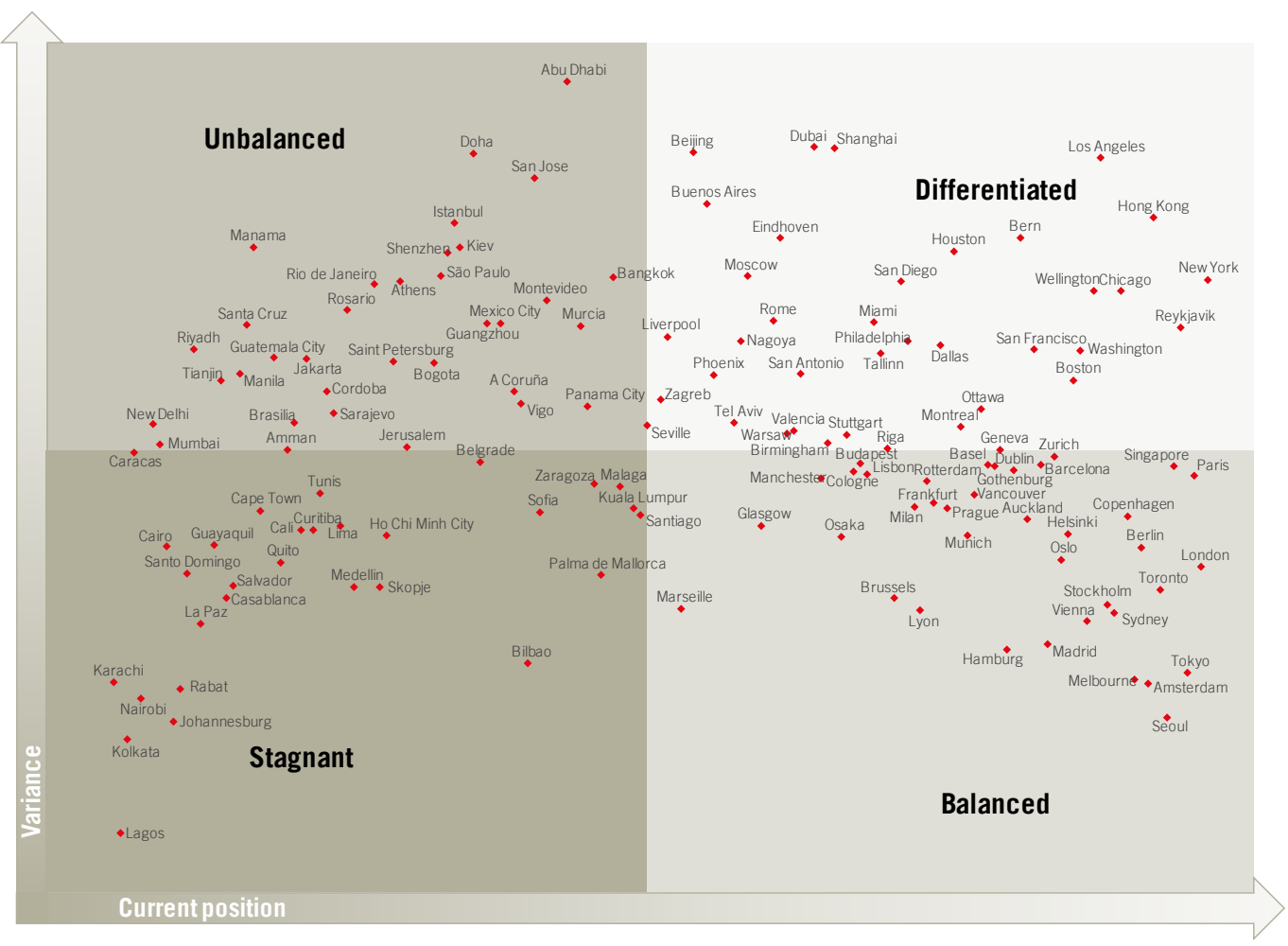


The CIMI synthetic index allows us, through an objective calculation methodology, to compile a ranking of cities taking into account various aspects. The different dimensions analyzed offer a broad and holistic vision of what a city represents, while allowing greater understanding of its composition and its evolution over time.

The results of the index and our experience of using it to assess different cities allow us to make the following recommendations and reach some significant conclusions:

- Size matters - although not so much. This new edition of the CIMI makes clear that large cities occupy leading positions in the ranking. The first 10 positions are held by megacities such as New York, London, Paris, Tokyo and Seoul. However, among the top positions some medium-sized cities stand out such as Amsterdam, Melbourne and Copenhagen and even some small cities, as in the cases of Reykjavik and Wellington. These results show that size is not a prerequisite for achieving top positions in the ranking.

- Finding the right balance is a complex (and permanent) process. The report's dynamic analysis indicates that only a select number of cities are capable of doing well in all the dimensions. (Cities such as Amsterdam, Seoul and Melbourne stand out.) Many cities struggle to balance their performance across different dimensions but often lose that battle. For example, when analyzing the relationship between mobility and the environment, we can see how several Chinese cities perform relatively well in their mobility and transportation model but fail in the environmental dimension. These cities could use as benchmarks other cities in the region (such as Seoul), which are able to perform well in both dimensions, and identify practices applicable to their situation. Something similar comes to light when studying the relationship between the economy and social cohesion. It can be observed here that there are many cities that have high economic levels (in average terms) but at the same time are more inequitable and unequal. This aspect, which seems prevalent in large cities (such as Hong Kong, New York, Los Angeles and London), must be managed properly as it can lead to tensions and conflicts between different strata in society. To do so, it is essential to identify where the "trade-offs" are and to look for creative ways to resolve them. Undoubtedly, one of the great challenges for cities is to transform themselves into urban centers that are simultaneously prosperous, equitable and inclusive. This goal is essentially a permanent and long-term process.

- Need for an overview. Related to the previous point, the CIMI makes clear that it is not enough to be good in only one dimension. There are cities that are at the top of the ranking in some dimensions. This is the case of Montevideo, Bangkok, Kiev and Doha, which do relatively well in the dimensions of the environment, international outreach, urban planning, and technology respectively but in the overall ranking are located in positions $100,90,113$, and 111 . These are the cities that we have called "unbalanced" in the analysis of variance. The recommendation for these cities is that, if they seek to play in the big leagues, they should be capable of reaching acceptable minimums in the dimensions as a whole. This message must also reach those cities that understand technology as the main (or only) ingredient of a smart city and do not take into account other critical dimensions that define the urban situation. If they do not see the whole picture, it will be difficult for them to become smart.

- The need for a long-term view. Cities need to define their identity and establish a strategic plan. One of the most important (and most difficult) questions a city has to ask itself is: What kind of city do you want in the future? The answer to this question will not only define the identity of the city but also set out the path of transformation that it must travel to achieve that identity. That is, it must consider what its strategic plan will be. A sound strategic plan will prevent changes that veer away from the city's identity as circumstances or governments change. Strategic plans must be unique and individual for each city. This means that cities must escape the one-size-fits-all approach. The CIMI makes clear that there is no single model of success. The cities that top the ranking are not identical but prioritize various dimensions. (See the graphical analysis appendix.) There are various ways through which a city can succeed in getting to the top of the index. 
- The first step is a good diagnosis. One of the first activities in any strategic definition is to understand the place in which we find ourselves. In this regard, the CIMI can be used as a diagnostic tool to carry out a first assessment of the current status of the city in the different dimensions of our model. The CIMI allows a quick $X$-ray to be taken of the cities, identifying their strengths and pointing out places where there is room for improvement.

- The benchmark as the beginning of change. The ability to compare 165 cities across nine different dimensions allows us to identify those that perform best in the different areas of the city. In this sense, cities that find themselves lagging behind or stagnant in one or more dimensions can study the best cities in each category to identify the best practices that allow them to perform better. This comparison will allow cities to start moving in the right direction. That said, it must be borne in mind that, while the challenges facing cities are global, their effects are local. Therefore, the benchmark should serve as a source of inspiration rather than as a road map for action. In this regard, IESE Cities in Motion has produced a series of books - available on Amazon - that identify good practices across the different dimensions and we invite readers to read them.

- The CIMI is not a "beauty contest." It has surprised us how many cities included in the index are more concerned about their position in the ranking than the analysis that can be derived from it. Our perspective is that the value of the CIMI lies not only in its ability to identify strengths and weaknesses but also in its temporal component, which enables identification of the direction in which each city is moving. In this regard, our recommendation to urban managers is that they pay more attention to the trend (dynamic analysis) than to the position.

- Collaboration as the cornerstone of success. Our experience from IESE Cities in Motion and the associated platform PPP for Cities (www.pppcities.org) tells us that the cities that do best in the ranking understand fully that the challenges facing cities are too big to be tackled individually. Collaboration is needed between different social partners, whether these be public, private, educational institutions, or nonprofit organizations. This collaboration can take on various formats (from PPP to collaborative economy structures) but they are essential for achieving long-term success. The notion of collaboration and cooperation should be extended within city councils themselves, where there are often "silos" that prevent people from seeing the relationships and the possible synergies that can occur among the different dimensions of our conceptual model. In addition, collaboration must be fluid between residents and the administration because otherwise any solutions that might be adopted will not be efficient when it comes to responding to the real needs of the community. Finally, we ask that cities collaborate with each other, especially those that, in addition to their proximity, share infrastructures and services. Collaboration will make them more efficient urban systems.

\section{- There are many good cities but the perfect city does} not exist. It is very difficult for a city to maximize all the dimensions. Even those cities in the top positions of the rankings have weak points. For example, cities such as London and New York have a long way to go in the social cohesion dimension. These cities have been classified as "differentiated" cities and we recommend that they make the most of the advantages they have in the dimensions where they are leaders in order to progress in the positions where they are lagging behind. For example, a city can make the most of its technological leadership to improve its environmental dimension. In addition, for the cities that we have classified as "balanced," the main recommendation is that they should not rest on their laurels. Despite their more harmonious growth, they still have room for improvement.

- Change is slow for most cities. While our temporal analysis of the CIMI indicates that there are cities capable of making great progress in a relatively short time and of moving to higher positions quickly (Milan, A Coruña, Birmingham), in general it shows us that, for most of the cities, a city's position in the ranking have not changed significantly from one year to the next. This is due, to a large extent, to the time that projects of any magnitude need to crystallize. Therefore, when seeking to generate changes needed to become smart and sustainable, cities should adopt long-term policies as soon as possible, especially those cities that are the worst placed and that we have called "stagnant" in our analysis. There are many cities that still have problems when it comes to dealing with the major challenges of cities, including: the lack of collaboration between public and private bodies, civic institutions and the public; the impossibility of promoting new business models that provide financing for new businesses; and a shortsighted vision of smart cities. 
The urbanization process is one of the most significant challenges of the 21st century. As the world population moves toward cities, existing problems grow and new ones are generated that, in addition, are influenced profoundly by the globalization process. This trend means a closer relationship between global dynamics and cities, generating local impacts: effects on the economy, demographics, social divisions or environmental impacts.

Despite these challenges, cities and their leaders should understand the positive aspect that cities have. From our perspective, the city offers a much more delimited sphere of action, which enables work to be done more directly for people's benefit. However, urban managers must take a step back and analyze their problems, try to discover what other cities do, and learn what good practices are being carried out elsewhere in the world. The day-to-day management of a city makes it difficult for cities to ask themselves how to promote the positive effects of the urbanization process and how to reduce the negative ones. That is why, from the IESE Cities in Motion platform, we aim to create awareness and generate innovative tools to achieve smarter governments. With this index, we hope to have contributed to this goal. 


\section{APPENDIX 1. INDICATORS}

\begin{tabular}{|c|c|c|c|c|}
\hline NO. & INDICATOR & DESCRIPTION / UNIT OF MEASUREMENT & $\begin{array}{l}\text { DIMENSION / } \\
\text { CLUSTER }\end{array}$ & SOURCE \\
\hline 1 & Higher education & $\begin{array}{l}\text { Proportion of population with secondary and higher } \\
\text { education. }\end{array}$ & Human capital & Euromonitor \\
\hline 2 & Business schools & Number of business schools (top 100). & Human capital & Financial Times \\
\hline 3 & Movement of students & $\begin{array}{l}\text { International movement of higher-level students. } \\
\text { Number of students. }\end{array}$ & Human capital & UNESCO \\
\hline 4 & Universities & $\begin{array}{l}\text { Number of universities in the city that are in the top } \\
500 .\end{array}$ & Human capital & QS Top Universities \\
\hline 5 & Museums and art galleries & Number of museums and art galleries per city. & Human capital & OpenStreetMap \\
\hline 6 & Schools & Number of public or private schools per city. & Human capital & OpenStreetMap \\
\hline 7 & Theaters & Number of theaters per city. & Human capital & OpenStreetMap \\
\hline 8 & $\begin{array}{l}\text { Expenditure on leisure and } \\
\text { recreation }\end{array}$ & Expenditure on leisure and recreation per capita. & Human capital & Euromonitor \\
\hline 9 & $\begin{array}{l}\text { Expenditure on leisure and } \\
\text { recreation }\end{array}$ & $\begin{array}{l}\text { Expenditure on leisure and recreation. Expressed in } \\
\text { millions of U.S. dollars at } 2014 \text { prices. }\end{array}$ & Human capital & Euromonitor \\
\hline 10 & Ratio of deaths & Ratio of death per 100,000 inhabitants. & Social cohesion & Euromonitor \\
\hline 11 & Crime rate & Crime rate. & Social cohesion & Numbeo \\
\hline 12 & Health & Health index. & Social cohesion & Numbeo \\
\hline 13 & Unemployment & $\begin{array}{l}\text { Unemployment rate (number of unemployed out of } \\
\text { the workforce). }\end{array}$ & Social cohesion & Euromonitor \\
\hline 14 & Gini index & $\begin{array}{l}\text { The Gini index varies from } 0 \text { to } 100 \text {, with } 0 \text { being a } \\
\text { situation of perfect equality and } 100 \text { that of perfect } \\
\text { inequality. }\end{array}$ & Social cohesion & Euromonitor \\
\hline 15 & Price of property & Price of property as percentage of income. & Social cohesion & Numbeo \\
\hline 16 & Ratio of female workers. & Ratio of female workers in the public administration. & Social cohesion & $\begin{array}{l}\text { International } \\
\text { Labour } \\
\text { Organization }\end{array}$ \\
\hline 17 & Global Peace Index & $\begin{array}{l}\text { The Global Peace Index is an indicator that } \\
\text { measures the peacefulness and the absence of } \\
\text { violence in a country or region. The bottom-ranking } \\
\text { positions correspond to countries with a high level } \\
\text { of violence. }\end{array}$ & Social cohesion & $\begin{array}{l}\text { Institute for } \\
\text { Economics and } \\
\text { Peace }\end{array}$ \\
\hline 18 & Hospitals & $\begin{array}{l}\text { Number of public and private hospitals and health } \\
\text { centers per city. }\end{array}$ & Social cohesion & OpenStreetMap \\
\hline 19 & Happiness index & $\begin{array}{l}\text { Happiness index of a country. The highest values } \\
\text { on the index indicate countries that have a higher } \\
\text { degree of overall happiness. }\end{array}$ & Social cohesion & $\begin{array}{l}\text { World happiness } \\
\text { index }\end{array}$ \\
\hline 20 & Global Slavery Index & $\begin{array}{l}\text { Ranking that considers the proportion of people in } \\
\text { a situation of slavery in the country. The countries } \\
\text { occupying the top positions in the ranking are those } \\
\text { with the highest proportion of the population in a } \\
\text { situation of slavery. }\end{array}$ & Social cohesion & $\begin{array}{l}\text { Walk Free } \\
\text { Foundation }\end{array}$ \\
\hline
\end{tabular}




\begin{tabular}{|c|c|c|c|c|}
\hline No. & INDICATOR & DESCRIPTION / UNIT OF MEASUREMENT & $\begin{array}{l}\text { DIMENSION / } \\
\text { CLUSTER }\end{array}$ & SOURCE \\
\hline 21 & $\begin{array}{l}\text { Government response to situations of } \\
\text { slavery }\end{array}$ & $\begin{array}{l}\text { This variable measures how the government deals } \\
\text { with situations of slavery in the country. The top } \\
\text { positions in the ranking indicate countries that have } \\
\text { a more effective and comprehensive response to } \\
\text { slavery. }\end{array}$ & Social cohesion & $\begin{array}{l}\text { Walk Free } \\
\text { Foundation }\end{array}$ \\
\hline 22 & Terrorism & $\begin{array}{l}\text { Number of terrorist acts of vandalism by city in the } \\
\text { previous three years. }\end{array}$ & Social cohesion & $\begin{array}{l}\text { Global Terrorism } \\
\text { Database, } \\
\text { University of } \\
\text { Maryland }\end{array}$ \\
\hline 23 & Productivity & $\begin{array}{l}\text { Labor productivity calculated as GDP per working } \\
\text { population (in thousands). }\end{array}$ & Economy & Euromonitor \\
\hline 24 & Time required to start a business & $\begin{array}{l}\text { Number of calendar days needed so a business } \\
\text { can operate legally. }\end{array}$ & Economy & World Bank \\
\hline 25 & Ease of starting a business & $\begin{array}{l}\text { Ease of starting a business. Top positions in the } \\
\text { ranking indicate a more favorable regulatory } \\
\text { environment for creating and operating a local } \\
\text { company. }\end{array}$ & Economy & World Bank \\
\hline 26 & Headquarters & $\begin{array}{l}\text { Number of headquarters of publicly traded } \\
\text { companies. }\end{array}$ & Economy & $\begin{array}{l}\text { Globalization } \\
\text { and World Cities } \\
\text { (GaWC) }\end{array}$ \\
\hline 27 & $\begin{array}{l}\text { Motivation for early-stage } \\
\text { entrepreneurial activity }\end{array}$ & $\begin{array}{l}\text { Percentage of people involved in total } \\
\text { entrepreneurial activity (TEA) who are motivated } \\
\text { by an opportunity for improvement, divided by } \\
\text { the percentage of TEA motivated by need. Total } \\
\text { entrepreneurial activity (TEA): new entrepreneurs or } \\
\text { owners/managers of a new business. }\end{array}$ & Economy & $\begin{array}{l}\text { Global } \\
\text { Entrepreneurship } \\
\text { Monitor }\end{array}$ \\
\hline 28 & Growth forecast & Forecast of annual GDP growth rate. & Economy & Euromonitor \\
\hline 29 & GDP & $\begin{array}{l}\text { Gross domestic product in millions of U.S. dollars at } \\
2014 \text { prices. }\end{array}$ & Economy & Euromonitor \\
\hline 30 & GDP per capita & Gross domestic product per capita at 2014 prices. & Economy & Euromonitor \\
\hline 31 & Reserves & $\begin{array}{l}\text { Total reserves in millions of current U.S. dollars. } \\
\text { Estimate at city level according to the population. }\end{array}$ & Governance & World Bank \\
\hline 32 & Reserves per capita & $\begin{array}{l}\text { Reserves per capita in millions of current U.S. } \\
\text { dollars. }\end{array}$ & Governance & World Bank \\
\hline 33 & Embassies & Number of embassies per city. & Governance & OpenStreetMap \\
\hline 34 & ISO 37120 certification & $\begin{array}{l}\text { This establishes whether or not the city has ISO } \\
37120 \text { certification. Certified cities are committed to } \\
\text { improving their services and quality of life. Variable } \\
\text { coded from } 0 \text { to } 6 \text {. Cities that have been certified } \\
\text { for the longest time have the highest value. The } \\
\text { value } 0 \text { is for cities without certification. }\end{array}$ & Governance & $\begin{array}{l}\text { World Council on } \\
\text { City Data (WCCD) }\end{array}$ \\
\hline 35 & Research centers & $\begin{array}{l}\text { Number of research and technology centers per } \\
\text { city. }\end{array}$ & Governance & OpenStreetMap \\
\hline
\end{tabular}




\begin{tabular}{|c|c|c|c|c|}
\hline No. & INDICATOR & DESCRIPTION / UNIT OF MEASUREMENT & $\begin{array}{l}\text { DIMENSION / } \\
\text { CLUSTER }\end{array}$ & SOURCE \\
\hline 36 & Strength of legal rights & $\begin{array}{l}\text { The strength of legal rights index measures the } \\
\text { degree to which collateral and bankruptcy laws } \\
\text { protect the rights of borrowers and lenders and thus } \\
\text { facilitate access to loans. The values go from } 0= \\
\text { low to } 12=\text { high, where the highest ratings indicate } \\
\text { that the laws are better designed to expand access } \\
\text { to credit. }\end{array}$ & Governance & World Bank \\
\hline 37 & Corruption perceptions & $\begin{array}{l}\text { Corruption perceptions index. Countries with values } \\
\text { close to } 0 \text { are perceived as very corrupt and those } \\
\text { with an index close to } 100 \text { are perceived as very } \\
\text { transparent. }\end{array}$ & Governance & $\begin{array}{l}\text { Transparency } \\
\text { International }\end{array}$ \\
\hline 38 & Open data platform & $\begin{array}{l}\text { This describes whether the city has an open data } \\
\text { system. }\end{array}$ & Governance & $\begin{array}{l}\text { CTIC Foundation } \\
\text { and Open World } \\
\text { Bank }\end{array}$ \\
\hline 39 & E-Government Development Index & $\begin{array}{l}\text { The E-Government Development Index (EGDI) } \\
\text { reflects how a country is using information } \\
\text { technology to promote access and inclusion for its } \\
\text { people. }\end{array}$ & Governance & United Nations \\
\hline 40 & Democracy & $\begin{array}{l}\text { Ranking where the countries in the highest } \\
\text { positions are those considered more democratic. }\end{array}$ & Governance & The Economist \\
\hline 41 & Government buildings & $\begin{array}{l}\text { Number of government buildings and premises in } \\
\text { the city. }\end{array}$ & Governance & OpenStreetMap \\
\hline 42 & $\mathrm{CO}_{2}$ emissions & $\begin{array}{l}\text { Carbon dioxide emissions that come from the } \\
\text { burning of fossil fuels and the manufacture of } \\
\text { cement. Measured in kilotons (kt). }\end{array}$ & The environment & World Bank \\
\hline 43 & $\mathrm{CO}_{2}$ emission index & $\mathrm{CO}_{2}$ emission index. & The environment & Numbeo \\
\hline 44 & Methane emissions & $\begin{array}{l}\text { Methane emissions that arise from human activities } \\
\text { such as agriculture and the industrial production of } \\
\text { methane. Measured in kt of } \mathrm{CO}_{2} \text { equivalent. }\end{array}$ & The environment & World Bank \\
\hline 45 & Access to the water supply & $\begin{array}{l}\text { Percentage of the population with reasonable } \\
\text { access to an appropriate quantity of water resulting } \\
\text { from an improvement in the water supply. }\end{array}$ & The environment & World Bank \\
\hline 46 & PM2.5 & $\begin{array}{l}\text { PM2.5 measures the number of particles in the air } \\
\text { whose diameter is less than } 2.5 \mu \mathrm{m} \text {. Annual mean. }\end{array}$ & The environment & $\begin{array}{l}\text { World Health } \\
\text { Organization }\end{array}$ \\
\hline 47 & PM10 & $\begin{array}{l}\text { PM10 measures the number of particles in the air } \\
\text { whose diameter is less than } 10 \mu \mathrm{m} \text {. Annual mean. }\end{array}$ & The environment & $\begin{array}{l}\text { World Health } \\
\text { Organization }\end{array}$ \\
\hline 48 & Pollution & Pollution index. & The environment & Numbeo \\
\hline 49 & Environmental performance index & $\begin{array}{l}\text { This measures environmental health and ecosystem } \\
\text { vitality. Scale from } 1 \text { (poor) to } 100 \text { (good). }\end{array}$ & The environment & Yale University \\
\hline 50 & Renewable water resources & Total renewable water sources per capita. & The environment & FAO \\
\hline
\end{tabular}




\begin{tabular}{|c|c|c|c|c|}
\hline No. & INDICATOR & DESCRIPTION / UNIT OF MEASUREMENT & $\begin{array}{l}\text { DIMENSION / } \\
\text { CLUSTER }\end{array}$ & SOURCE \\
\hline 51 & Future climate & $\begin{array}{l}\text { Percentage of summer temperature increase in the } \\
\text { city forecast for } 2100 \text { if carbon pollution continues } \\
\text { to increase. }\end{array}$ & The environment & Climate Central \\
\hline 52 & Solid waste & $\begin{array}{l}\text { Average amount of municipal solid waste (garbage) } \\
\text { generated annually per person (kg/yr). }\end{array}$ & The environment & $\begin{array}{l}\text { Waste } \\
\text { Management for } \\
\text { Everyone }\end{array}$ \\
\hline 53 & Traffic index & $\begin{array}{l}\text { The traffic index is estimated by considering } \\
\text { the time spent in traffic and the dissatisfaction } \\
\text { this generates. It also includes estimates of } \mathrm{CO}_{2} \\
\text { consumption and the other inefficiencies of the } \\
\text { traffic system. }\end{array}$ & $\begin{array}{l}\text { Mobility and } \\
\text { transportation }\end{array}$ & Numbeo \\
\hline 54 & Inefficiency index & $\begin{array}{l}\text { The inefficiency index is an estimate of the } \\
\text { inefficiencies in traffic. High values represent high } \\
\text { rates of inefficiency in driving, such as long journey } \\
\text { times. }\end{array}$ & $\begin{array}{l}\text { Mobility and } \\
\text { transportation }\end{array}$ & Numbeo \\
\hline 55 & $\begin{array}{l}\text { Index of time spent commuting to } \\
\text { work }\end{array}$ & $\begin{array}{l}\text { Index of time based on how many minutes it takes } \\
\text { to commute to work. }\end{array}$ & $\begin{array}{l}\text { Mobility and } \\
\text { transportation }\end{array}$ & Numbeo \\
\hline 56 & Bike sharing & $\begin{array}{l}\text { The bicycle-sharing system shows the automated } \\
\text { services for the public use of shared bicycles that } \\
\text { provide transport from one location to another } \\
\text { within a city. The indicator varies between } 0 \text { and } 8 \\
\text { according to how developed the system is. }\end{array}$ & $\begin{array}{l}\text { Mobility and } \\
\text { transportation }\end{array}$ & $\begin{array}{l}\text { Bike-Sharing World } \\
\text { Map }\end{array}$ \\
\hline 57 & Metro length & Length of the metro system per city. & $\begin{array}{l}\text { Mobility and } \\
\text { transportation }\end{array}$ & Metrobits.org \\
\hline 58 & Metro stations & Number of metro stations per city. & $\begin{array}{l}\text { Mobility and } \\
\text { transportation }\end{array}$ & Metrobits.org \\
\hline 59 & Flights & Number of arrival flights (air routes) in a city. & $\begin{array}{l}\text { Mobility and } \\
\text { transportation }\end{array}$ & OpenFlights \\
\hline 60 & Gas stations & Number of gas stations per city. & $\begin{array}{l}\text { Mobility and } \\
\text { transportation }\end{array}$ & OpenStreetMap \\
\hline 61 & High-speed train & $\begin{array}{l}\text { Binary variable that shows whether the city has a } \\
\text { high-speed train or not. }\end{array}$ & $\begin{array}{l}\text { Mobility and } \\
\text { transportation }\end{array}$ & OpenRailwayMap \\
\hline 62 & Bicycles for rent & $\begin{array}{l}\text { Number of bike-rental or bike-sharing points, based } \\
\text { on docking stations where they can be picked up or } \\
\text { dropped off. }\end{array}$ & Urban planning & OpenStreetMap \\
\hline 63 & $\begin{array}{l}\text { Percentage of the population with } \\
\text { access to sanitation facilities }\end{array}$ & $\begin{array}{l}\text { Percentage of the population with at least sufficient } \\
\text { access to facilities for the disposal of excreta that } \\
\text { can efficiently avoid the contact of humans, animals } \\
\text { and insects with excreta. }\end{array}$ & Urban planning & World Bank \\
\hline 64 & Number of people per household & $\begin{array}{l}\text { Number of people per household. Occupancy by } \\
\text { household is measured compared to the average. } \\
\text { This makes it possible to estimate if a city has } \\
\text { overoccupied or underoccupied households. }\end{array}$ & Urban planning & Euromonitor \\
\hline 65 & High-rise buildings & $\begin{array}{l}\text { Percentage of buildings that are considered high- } \\
\text { rises. A high-rise is a building of at least } 12 \text { stories } \\
\text { or } 35 \text { meters ( } 115 \text { feet) high. }\end{array}$ & Urban planning & $\begin{array}{l}\text { Skyscraper Source } \\
\text { Media }\end{array}$ \\
\hline 66 & Buildings & $\begin{array}{l}\text { The buildings variable is the number of completed } \\
\text { buildings in the city. This includes structures such } \\
\text { as high-rises, towers and smaller buildings but } \\
\text { excludes other diverse structures and buildings } \\
\text { in different states of completion (in construction, } \\
\text { planned, etc.). }\end{array}$ & Urban planning & $\begin{array}{l}\text { Skyscraper Source } \\
\text { Media }\end{array}$ \\
\hline
\end{tabular}




\begin{tabular}{|c|c|c|c|c|}
\hline NO. & INDICATOR & DESCRIPTION / UNIT OF MEASUREMENT & $\begin{array}{l}\text { DIMENSION / } \\
\text { CLUSTER }\end{array}$ & SOURCE \\
\hline 67 & McDonald's & Number of McDonald's restaurants per city. & $\begin{array}{l}\text { International } \\
\text { outreach }\end{array}$ & OpenStreetMap \\
\hline 68 & Airports & $\begin{array}{l}\text { Number of points where flight operations take } \\
\text { place within a } 40 \mathrm{~km} \text { radius from the latitude and } \\
\text { longitude defining the center of the city. It includes } \\
\text { airports, aerodromes, airfields, and landing strips } \\
\text { whether international, private, military or otherwise. } \\
\text { Also included are the buildings used for processing } \\
\text { passengers and cargo (terminals). }\end{array}$ & $\begin{array}{l}\text { International } \\
\text { outreach }\end{array}$ & OpenStreetMap \\
\hline 69 & Number of passengers per airport & Number of passengers per airport in thousands. & $\begin{array}{l}\text { International } \\
\text { outreach }\end{array}$ & Euromonitor \\
\hline 70 & Sightsmap & $\begin{array}{l}\text { Ranking of cities according to the number of } \\
\text { photos taken in the city and uploaded to Panoramio } \\
\text { (community for sharing photographs online). The } \\
\text { top positions correspond to the cities with the most } \\
\text { photographs. }\end{array}$ & $\begin{array}{l}\text { International } \\
\text { outreach }\end{array}$ & Sightsmap \\
\hline 71 & $\begin{array}{l}\text { Number of conferences and } \\
\text { meetings }\end{array}$ & $\begin{array}{l}\text { Number of international conferences and meetings } \\
\text { that take place in a city. }\end{array}$ & $\begin{array}{l}\text { International } \\
\text { outreach }\end{array}$ & $\begin{array}{l}\text { International } \\
\text { Congress and } \\
\text { Convention } \\
\text { Association }\end{array}$ \\
\hline 72 & Hotels & Number of hotels per capita. & $\begin{array}{l}\text { International } \\
\text { outreach }\end{array}$ & OpenStreetMap \\
\hline 73 & Twitter & $\begin{array}{l}\text { Registered Twitter users in the city. This is part of } \\
\text { the "social media" variable. }\end{array}$ & Technology & Tweet Map \\
\hline 74 & Linkedln & $\begin{array}{l}\text { Number of registered users in the city. This is part } \\
\text { of the "social media" variable. }\end{array}$ & Technology & Linkedln \\
\hline 75 & Facebook & $\begin{array}{l}\text { Number of people who are currently registered } \\
\text { in the city. Facebook is part of the "social media" } \\
\text { variable. }\end{array}$ & Technology & Facebook \\
\hline 76 & Mobile phones & $\begin{array}{l}\text { Number of mobile phones in the city. Taken at the } \\
\text { country level. }\end{array}$ & Technology & $\begin{array}{l}\text { International } \\
\text { Telecommunication } \\
\text { Union }\end{array}$ \\
\hline 77 & Wi-Fi hot spot & $\begin{array}{l}\text { Number of wireless access points globally. These } \\
\text { represent the options there are in the city for } \\
\text { connecting to the Internet. }\end{array}$ & Technology & Wifi map app \\
\hline 78 & Apple Store & Number of Apple Stores per city. & Technology & OpenStreetMap \\
\hline 79 & Innovation index & $\begin{array}{l}\text { The city's innovation index. Valuation of } 0=\text { no } \\
\text { innovation to } 60=\text { a lot of innovation. }\end{array}$ & Technology & $\begin{array}{l}\text { Innovation Cities } \\
\text { Program }\end{array}$ \\
\hline 80 & Landline subscriptions & $\begin{array}{l}\text { Number of landline subscriptions per } 100 \\
\text { inhabitants. }\end{array}$ & Technology & $\begin{array}{l}\text { International } \\
\text { Telecommunication } \\
\text { Union }\end{array}$ \\
\hline
\end{tabular}




\begin{tabular}{|c|c|c|c|c|}
\hline No. & INDICATOR & DESCRIPTION / UNIT OF MEASUREMENT & $\begin{array}{l}\text { DIMENSION / } \\
\text { CLUSTER }\end{array}$ & SOURCE \\
\hline 81 & Broadband subscriptions & Broadband subscriptions per 100 inhabitants. & Technology & $\begin{array}{l}\text { International } \\
\text { Telecommunication } \\
\text { Union }\end{array}$ \\
\hline 82 & Internet & $\begin{array}{l}\text { Percentage of households with access to the } \\
\text { Internet. }\end{array}$ & Technology & Euromonitor \\
\hline 83 & Mobile telephony & $\begin{array}{l}\text { Percentage of households with mobile phones in } \\
\text { the city. }\end{array}$ & Technology & Euromonitor \\
\hline 84 & Disposable income & $\begin{array}{l}\text { Disposable income (annual average). Decile } 1 . \\
\text { Expressed in U.S. dollars. }\end{array}$ & City cluster & Euromonitor \\
\hline 85 & Disposable income & $\begin{array}{l}\text { Disposable income (annual average). Decile } 2 . \\
\text { Expressed in U.S. dollars. }\end{array}$ & City cluster & Euromonitor \\
\hline 86 & Disposable income & $\begin{array}{l}\text { Disposable income (annual average). Decile } 5 . \\
\text { Expressed in U.S. dollars. }\end{array}$ & City cluster & Euromonitor \\
\hline 87 & Disposable income & $\begin{array}{l}\text { Disposable income (annual average). Decile } 7 . \\
\text { Expressed in U.S. dollars. }\end{array}$ & City cluster & Euromonitor \\
\hline 88 & Disposable income & $\begin{array}{l}\text { Disposable income (annual average). Decile } 9 . \\
\text { Expressed in U.S. dollars. }\end{array}$ & City cluster & Euromonitor \\
\hline 89 & Population & Number of inhabitants. & $\begin{array}{l}\text { City/country } \\
\text { cluster }\end{array}$ & Euromonitor \\
\hline 90 & Percentage of population employed & Percentage of population employed. & Country cluster & Euromonitor \\
\hline 91 & $\begin{array}{l}\text { Expenditure on education per } \\
\text { inhabitant }\end{array}$ & $\begin{array}{l}\text { Expenditure on education per inhabitant. Expressed } \\
\text { in millions of U.S. dollars at } 2015 \text { prices. }\end{array}$ & Country cluster & Euromonitor \\
\hline 92 & $\begin{array}{l}\text { Expenditure on medical and health } \\
\text { services per inhabitant }\end{array}$ & $\begin{array}{l}\text { Expenditure on medical and health services per } \\
\text { inhabitant. Expressed in millions of U.S. dollars at } \\
2015 \text { prices. }\end{array}$ & Country cluster & Euromonitor \\
\hline 93 & $\begin{array}{l}\text { Expenditure on hospitality and } \\
\text { catering services per inhabitant }\end{array}$ & $\begin{array}{l}\text { Expenditure on hospitality and catering services per } \\
\text { inhabitant. Expressed in millions of U.S. dollars at } \\
2015 \text { prices. }\end{array}$ & Country cluster & Euromonitor \\
\hline 94 & $\begin{array}{l}\text { Expenditure on housing per } \\
\text { inhabitant }\end{array}$ & $\begin{array}{l}\text { Expenditure on housing per inhabitant. Expressed } \\
\text { in millions of U.S. dollars at } 2015 \text { prices. }\end{array}$ & Country cluster & Euromonitor \\
\hline
\end{tabular}




\section{APPENDIX 2. \\ GRAPHICAL ANALYSIS OF \\ THE PROFILES OF 165 CITIES}

Below is a graphical analysis of the 165 cities included in the CIMI, based on the nine key dimensions. These radar charts aim to facilitate interpretation of each city's profile by identifying the values of the various dimen- sions. At the same time, they enable comparisons of two or more cities at a glance. The charts are sorted by ranking.
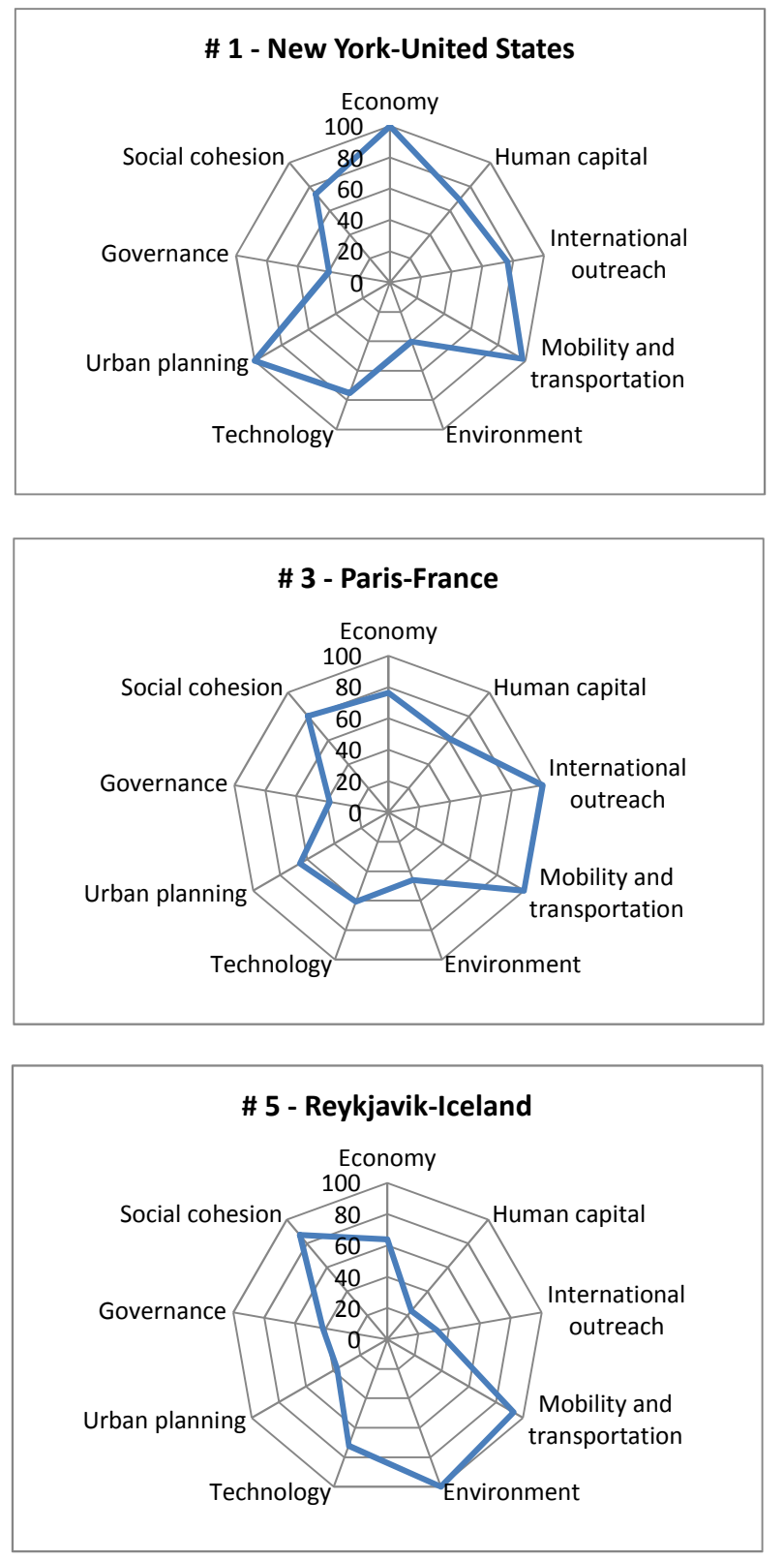
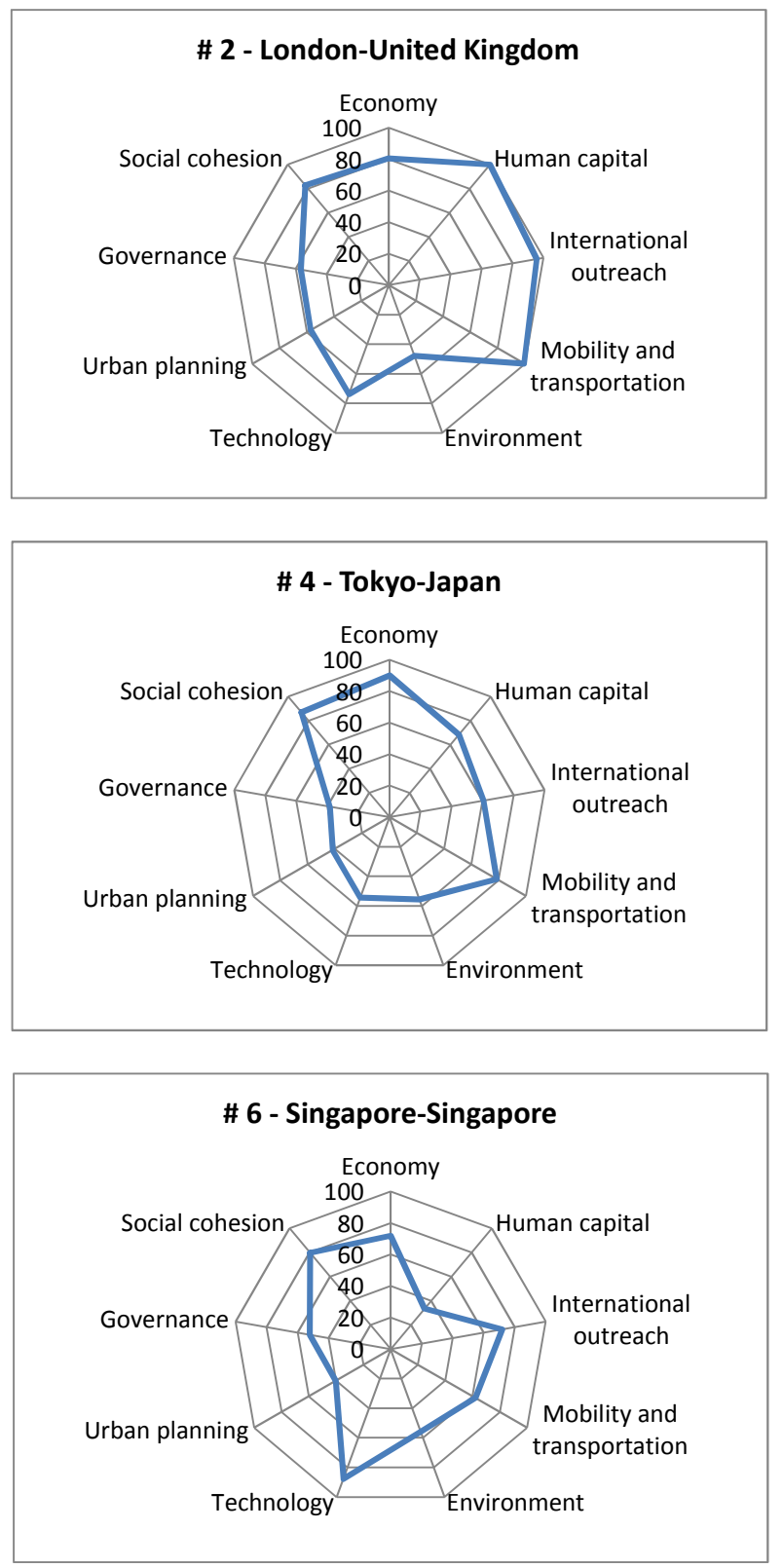

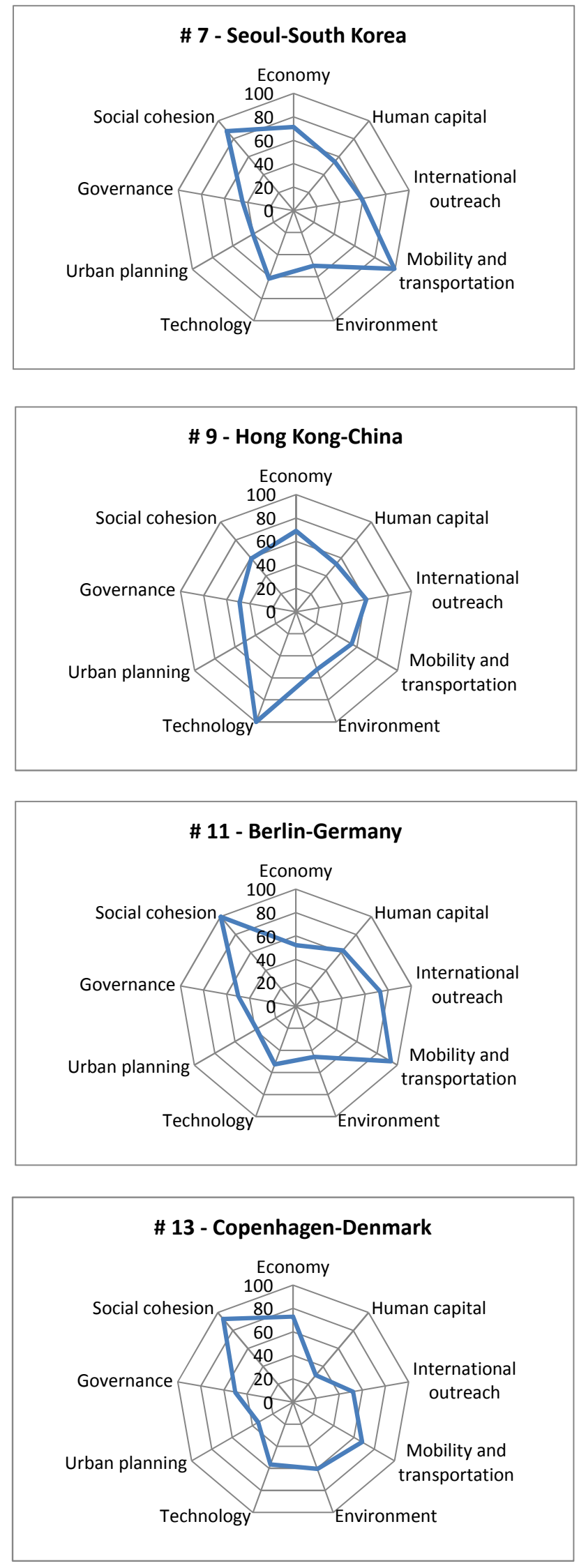
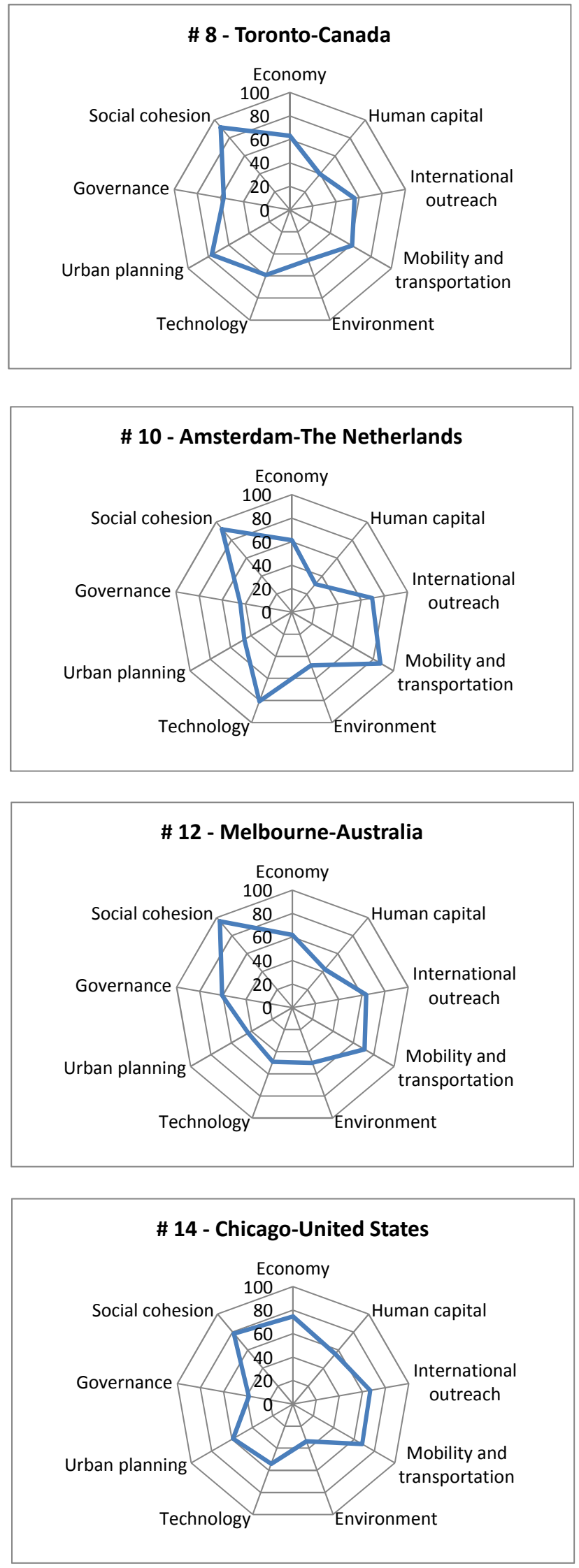

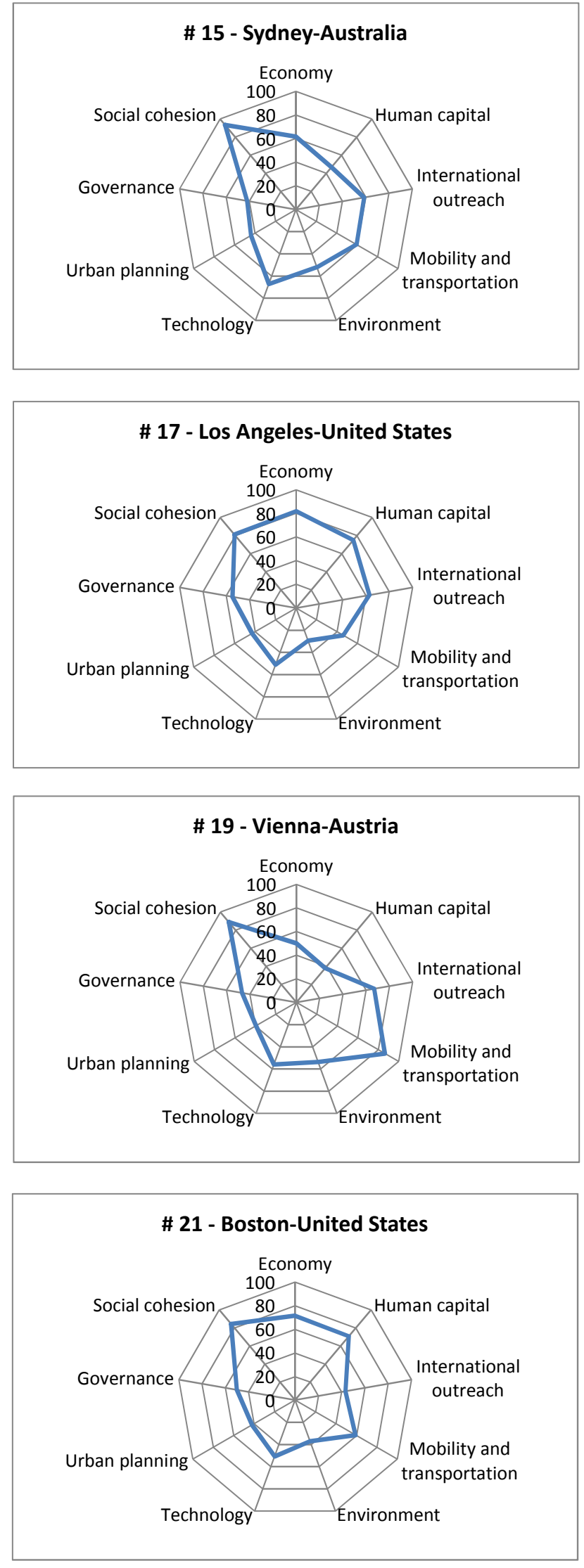
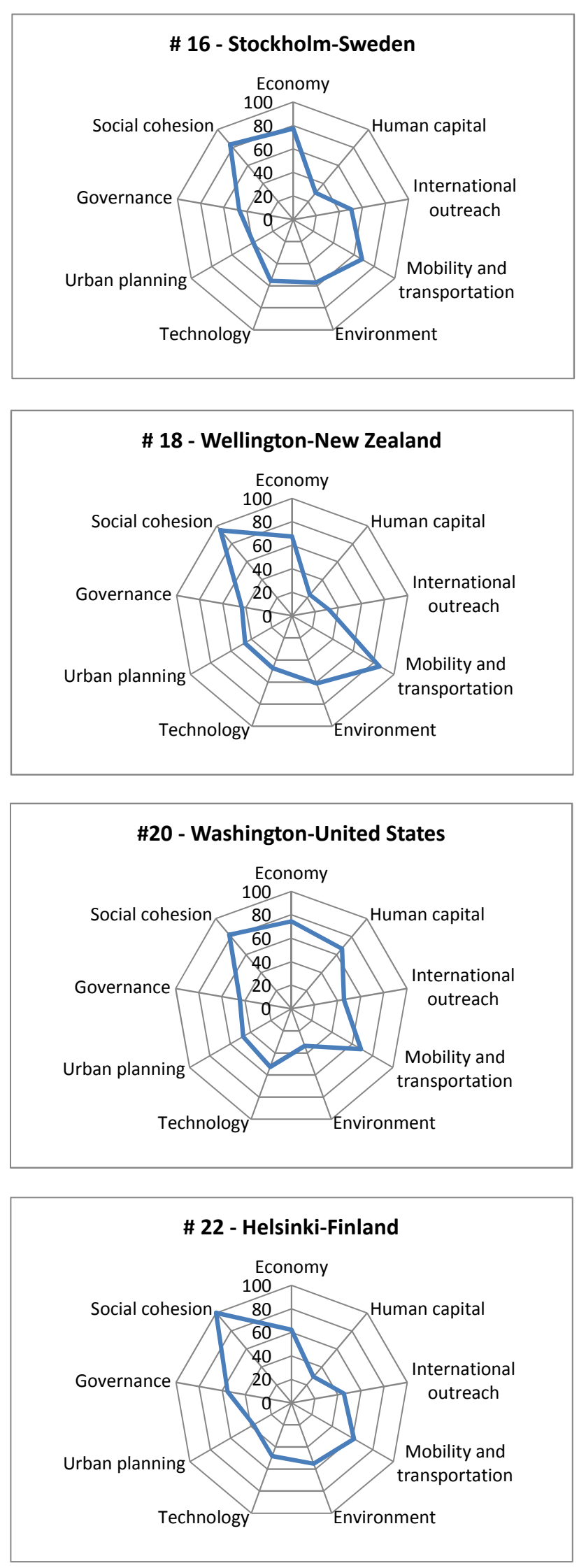

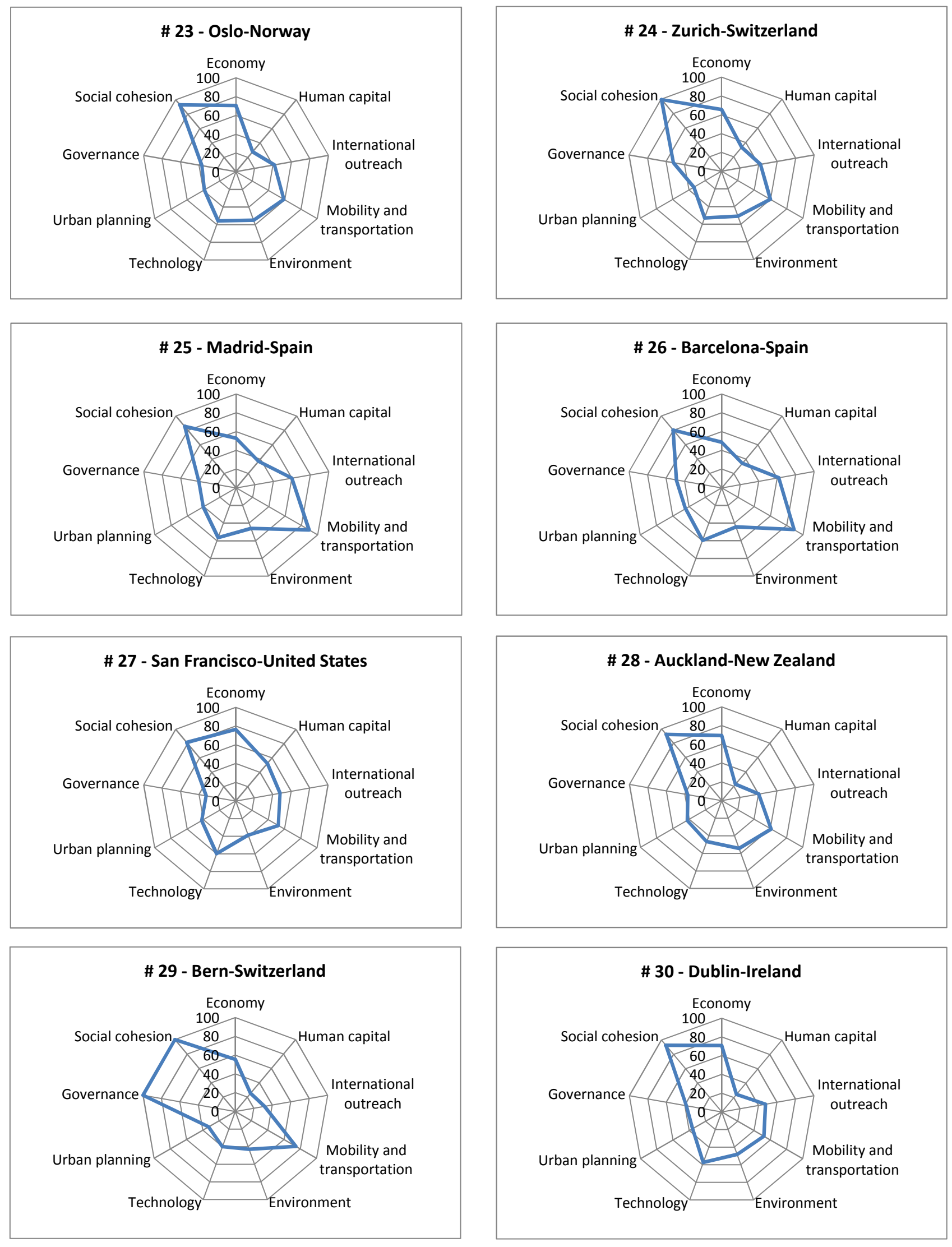

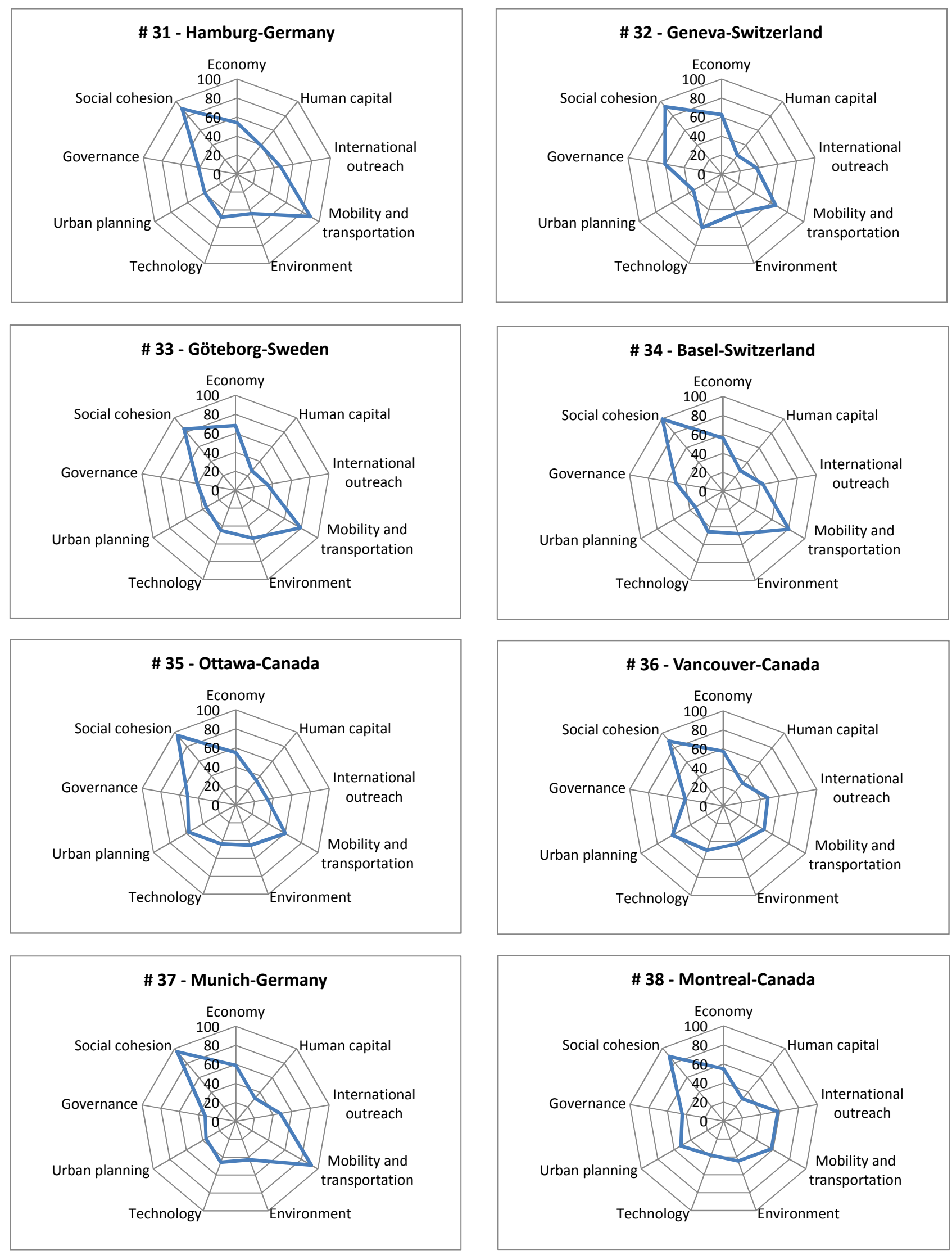

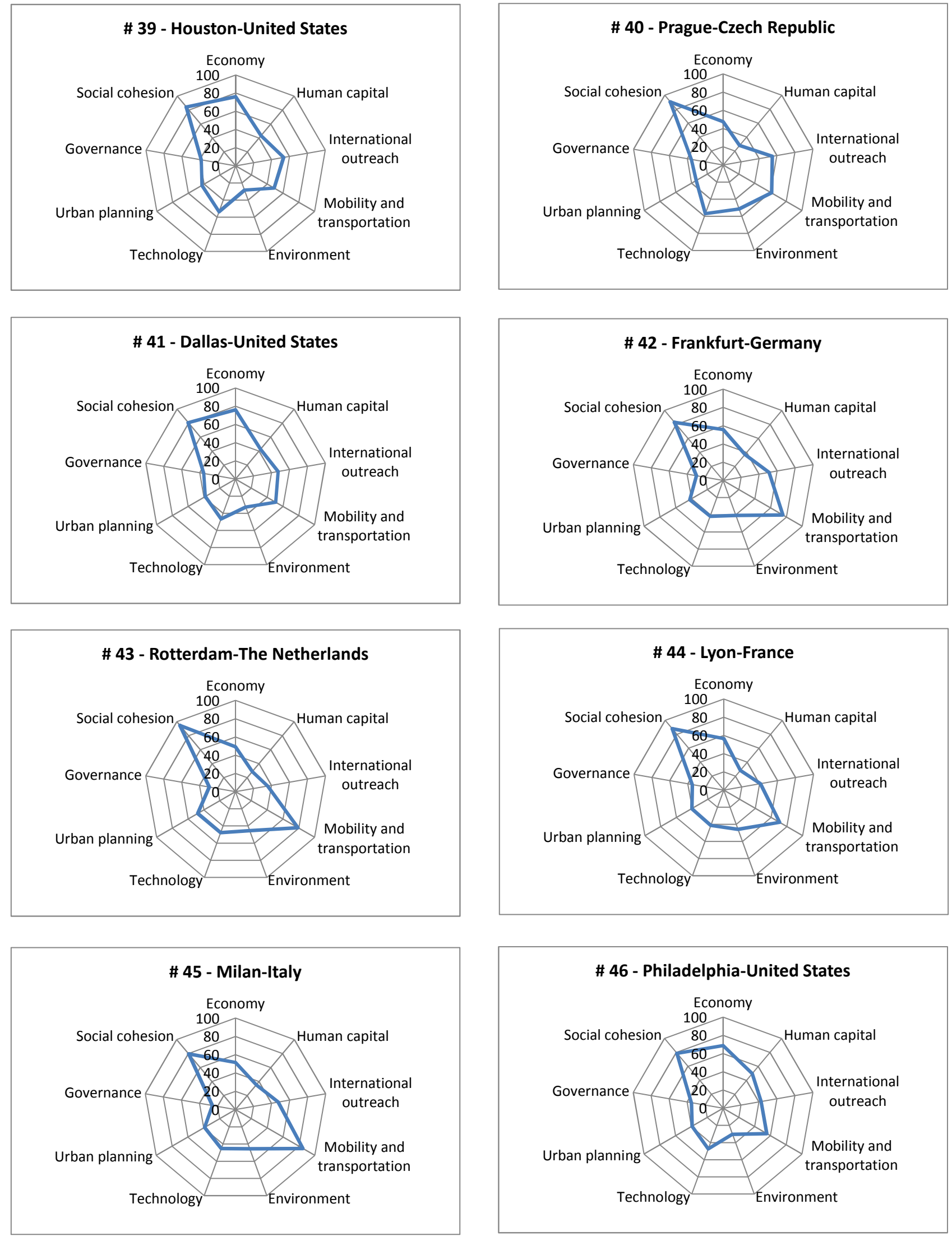

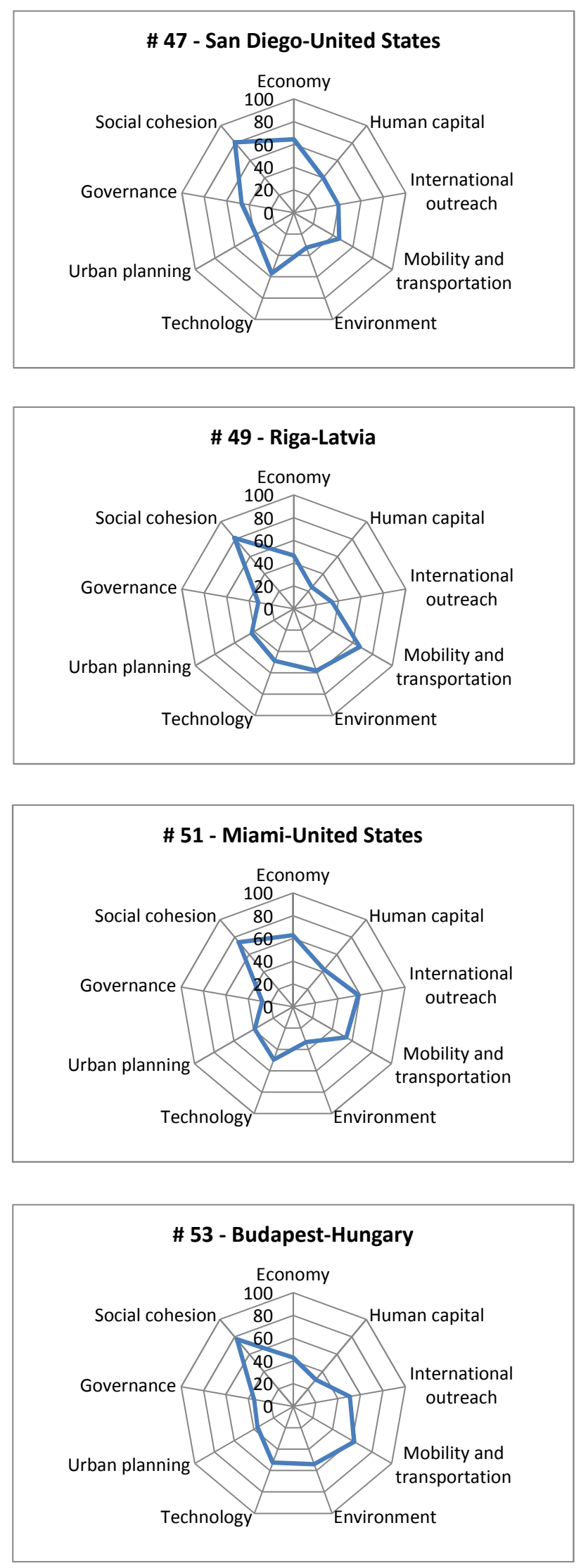
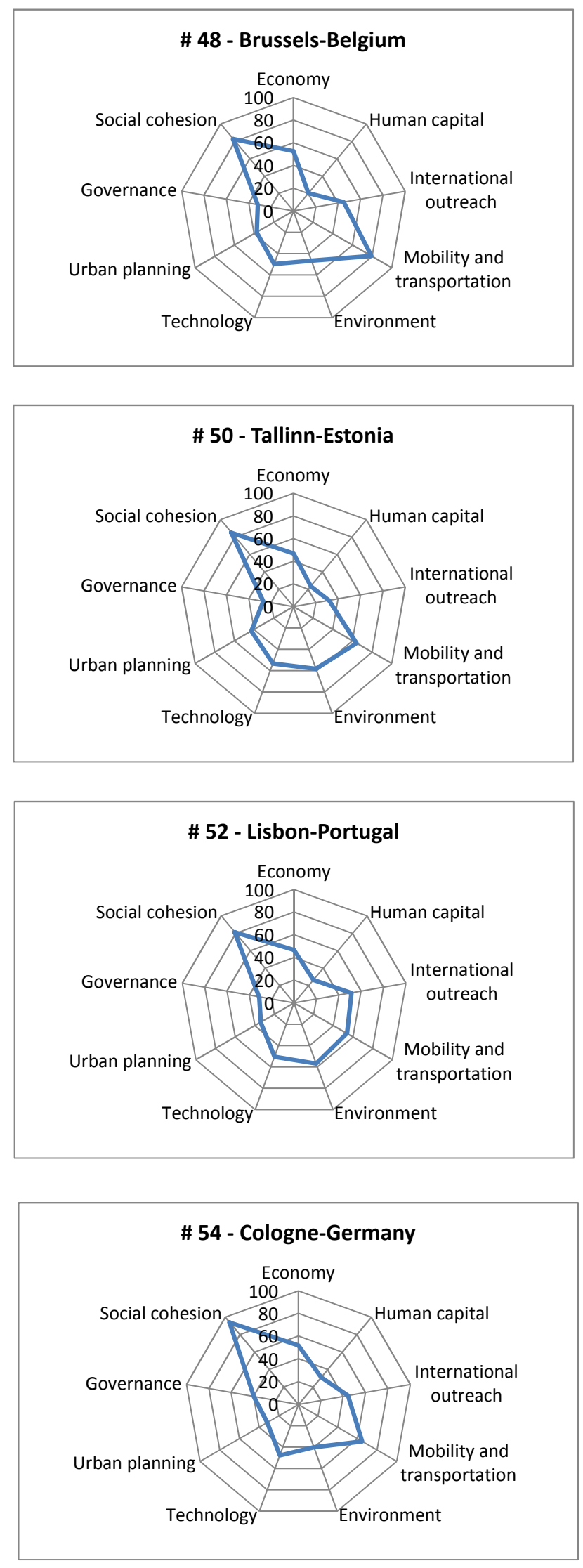

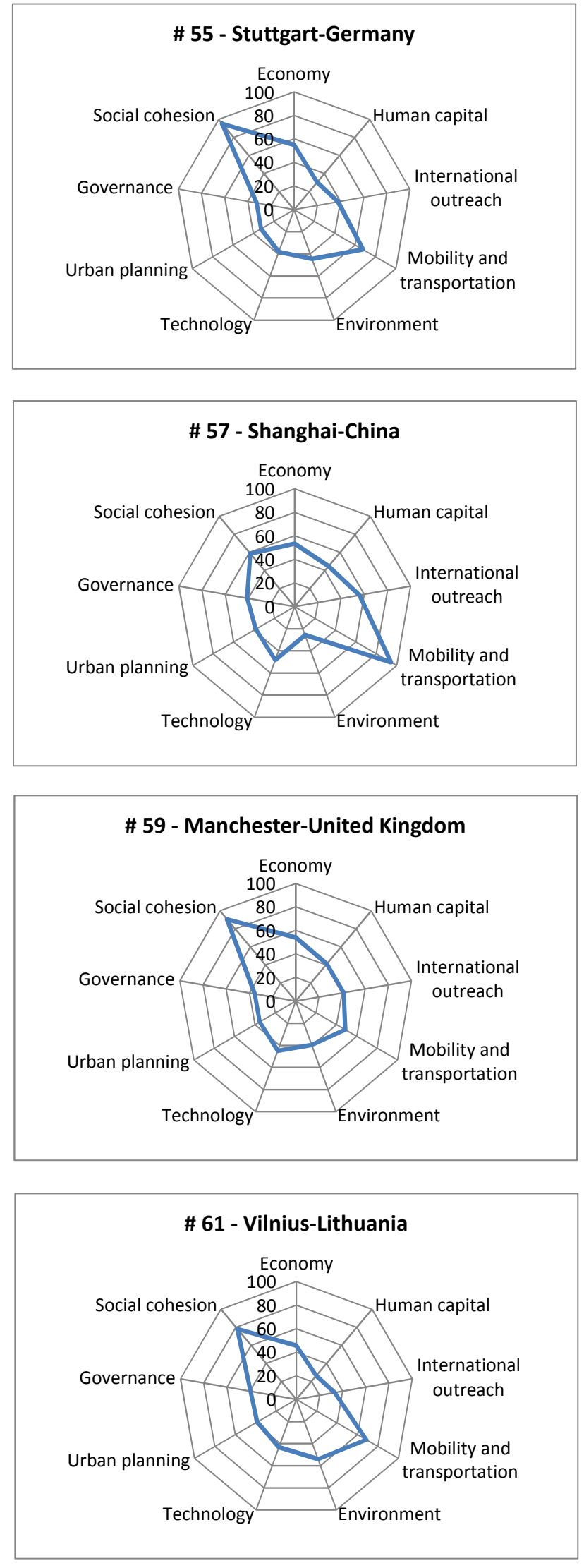
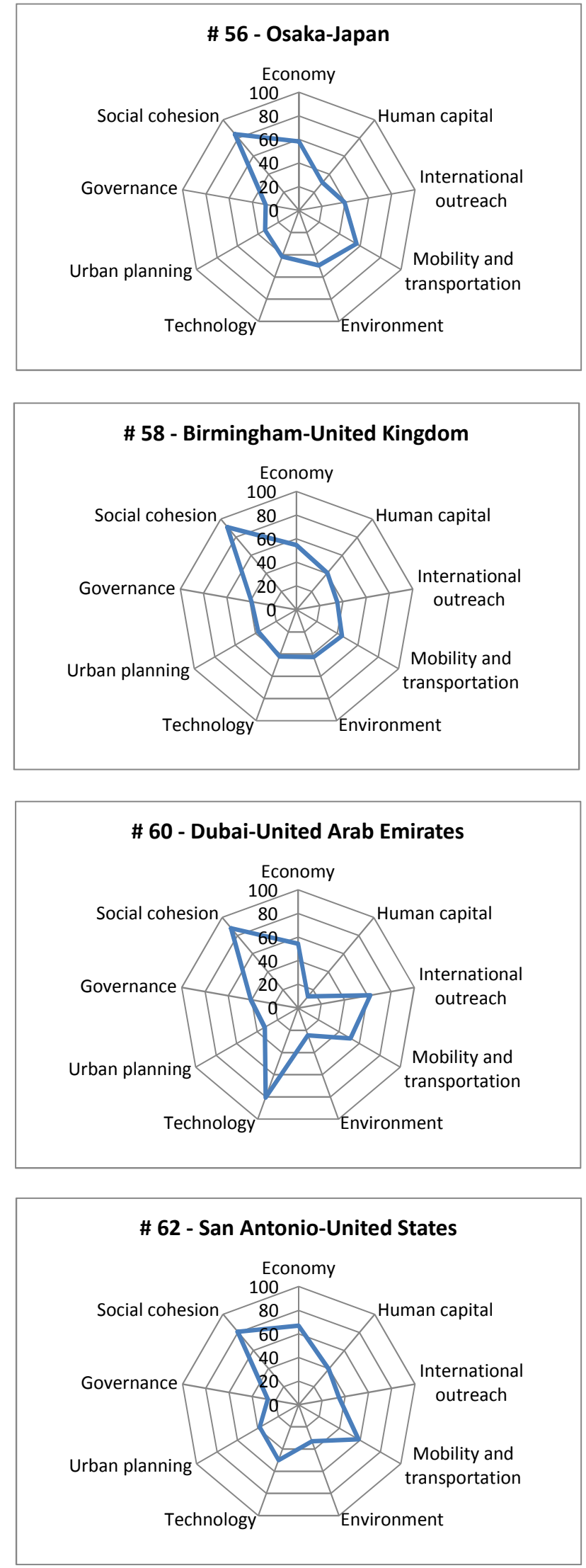

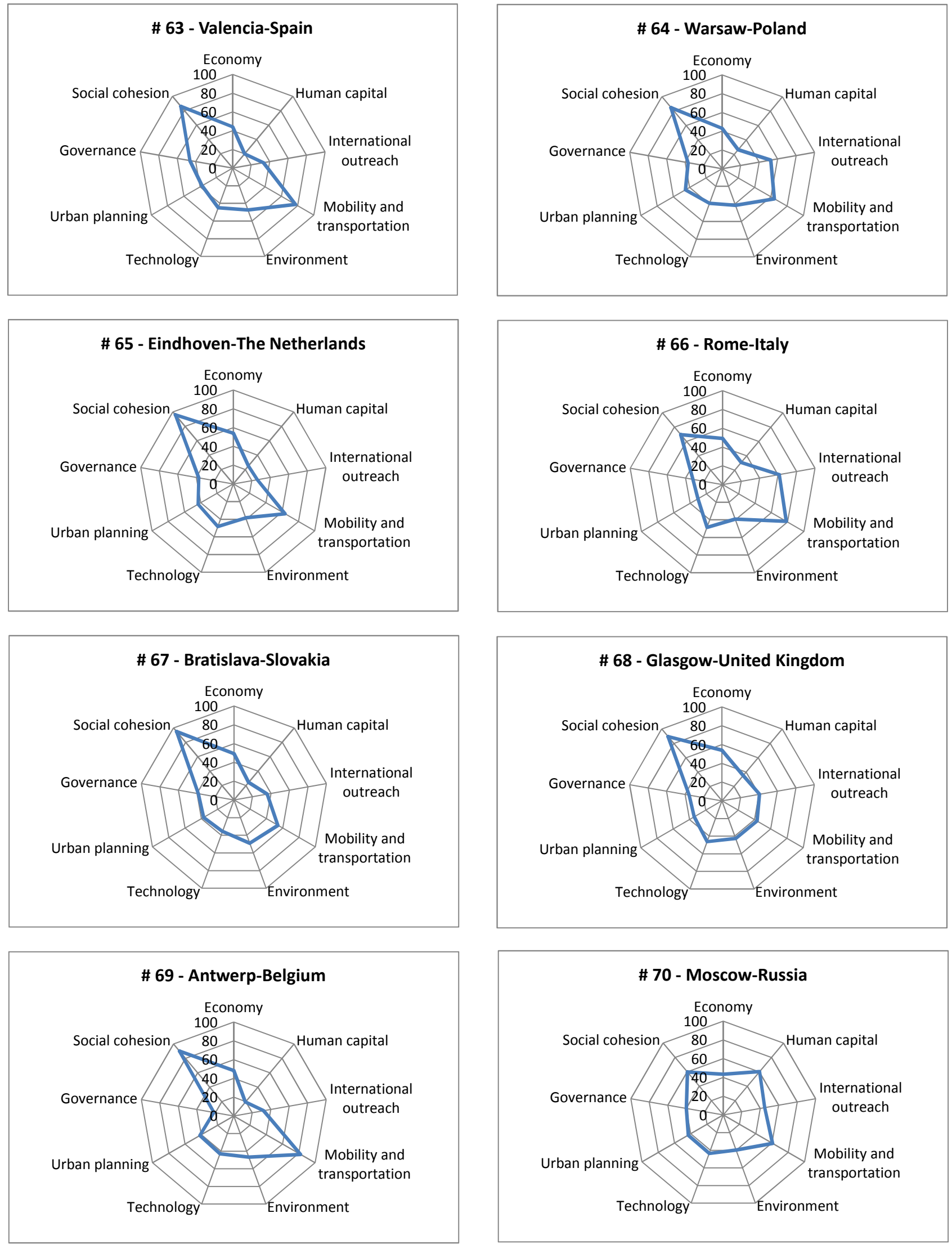

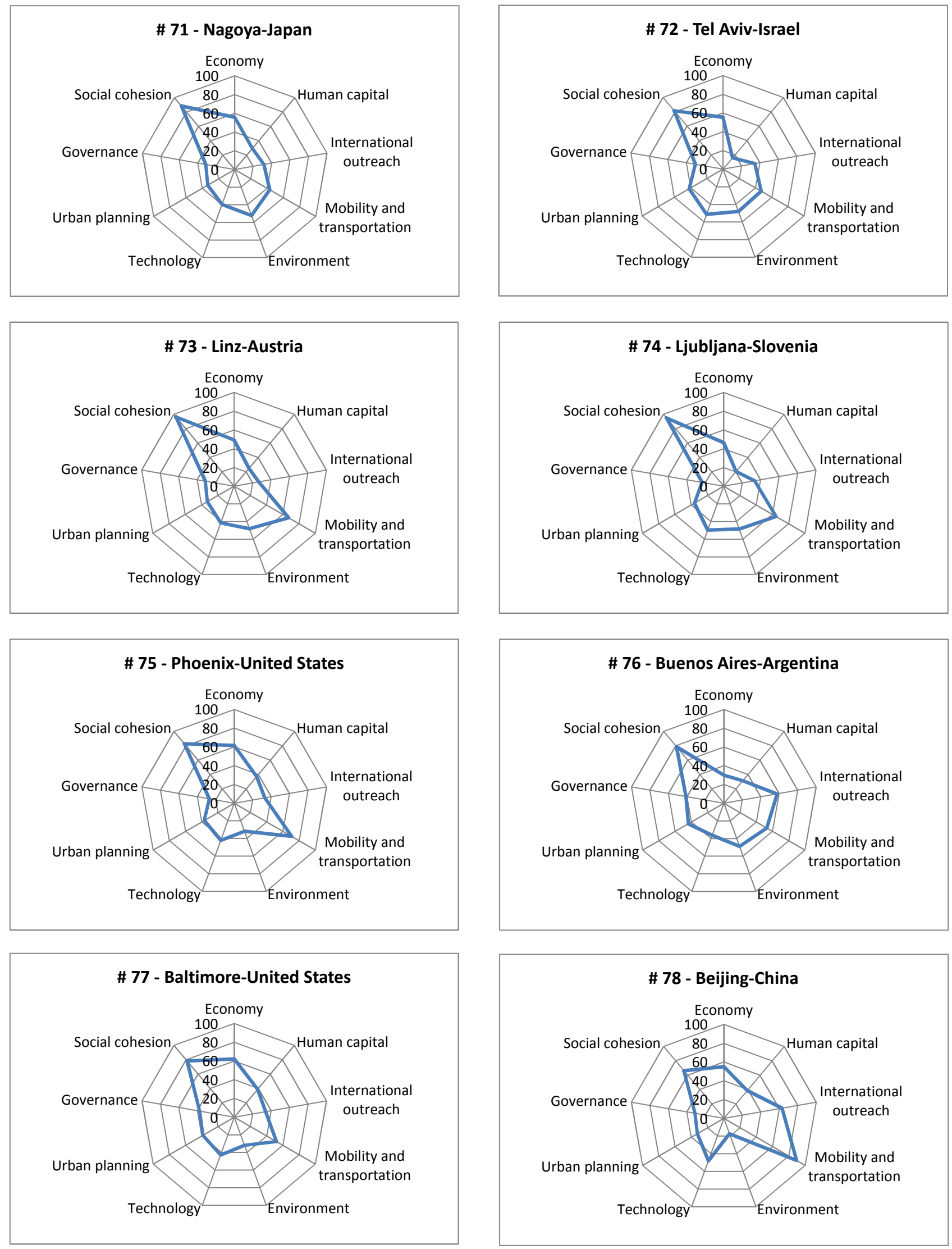

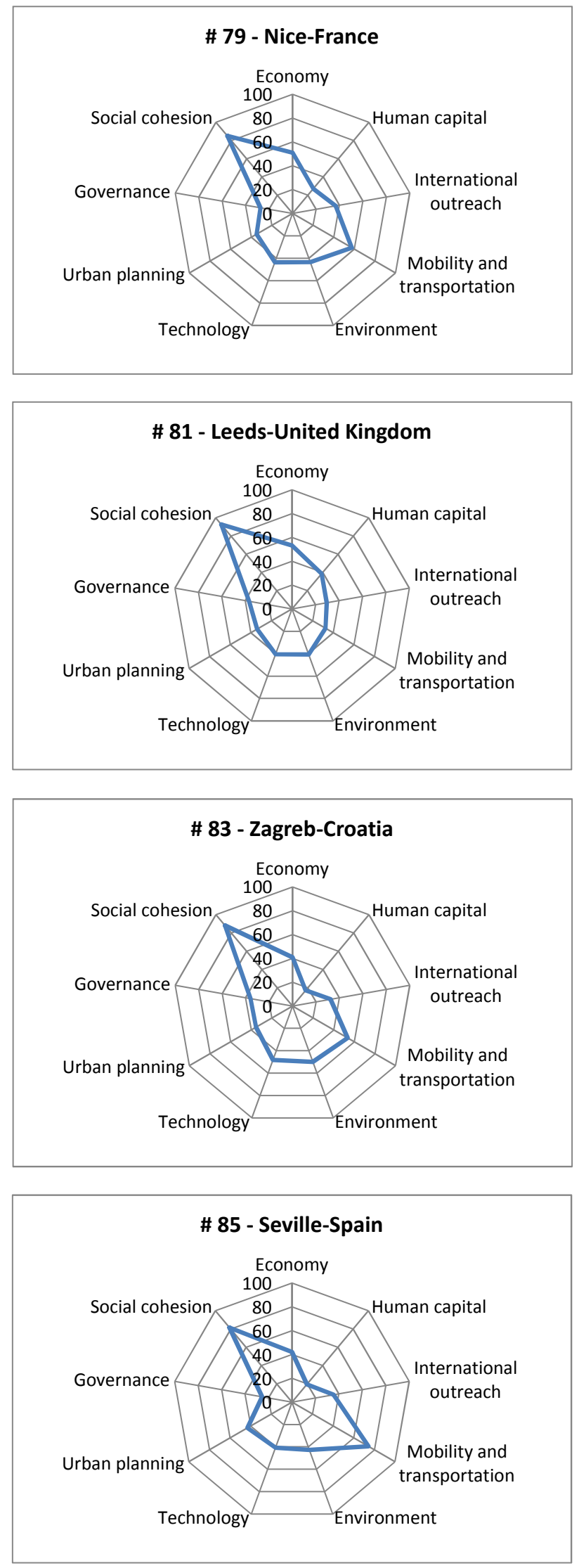
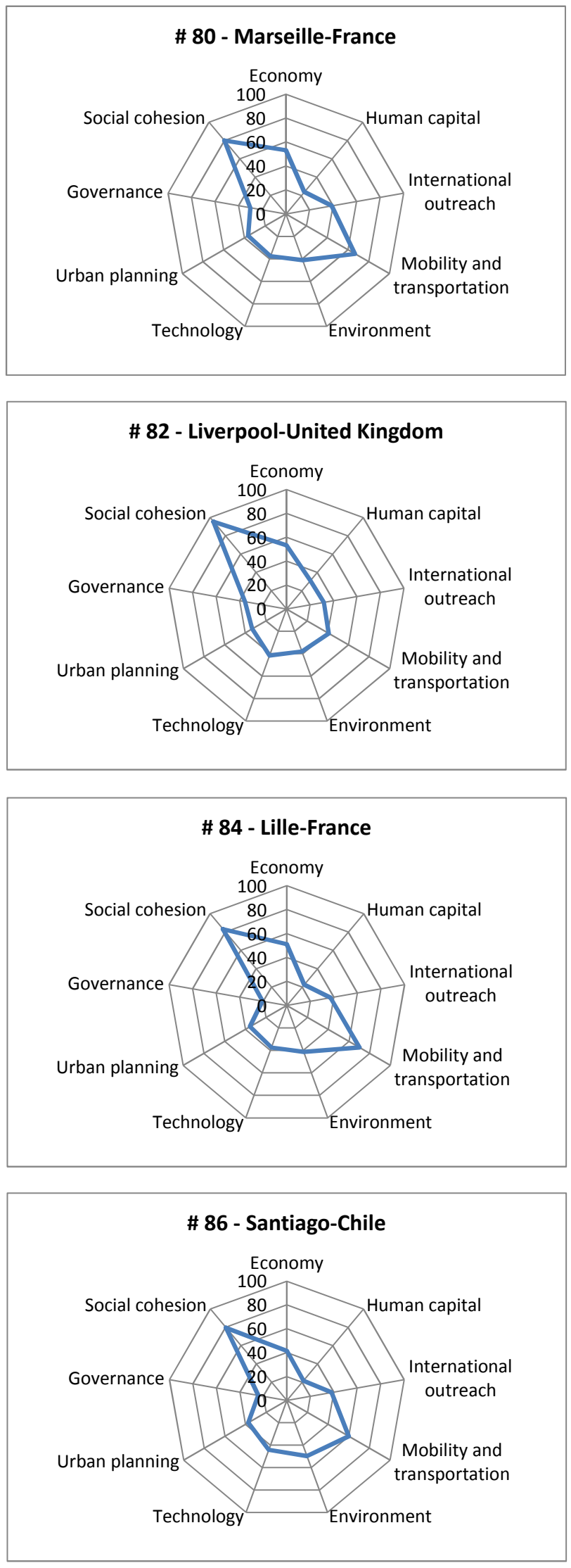

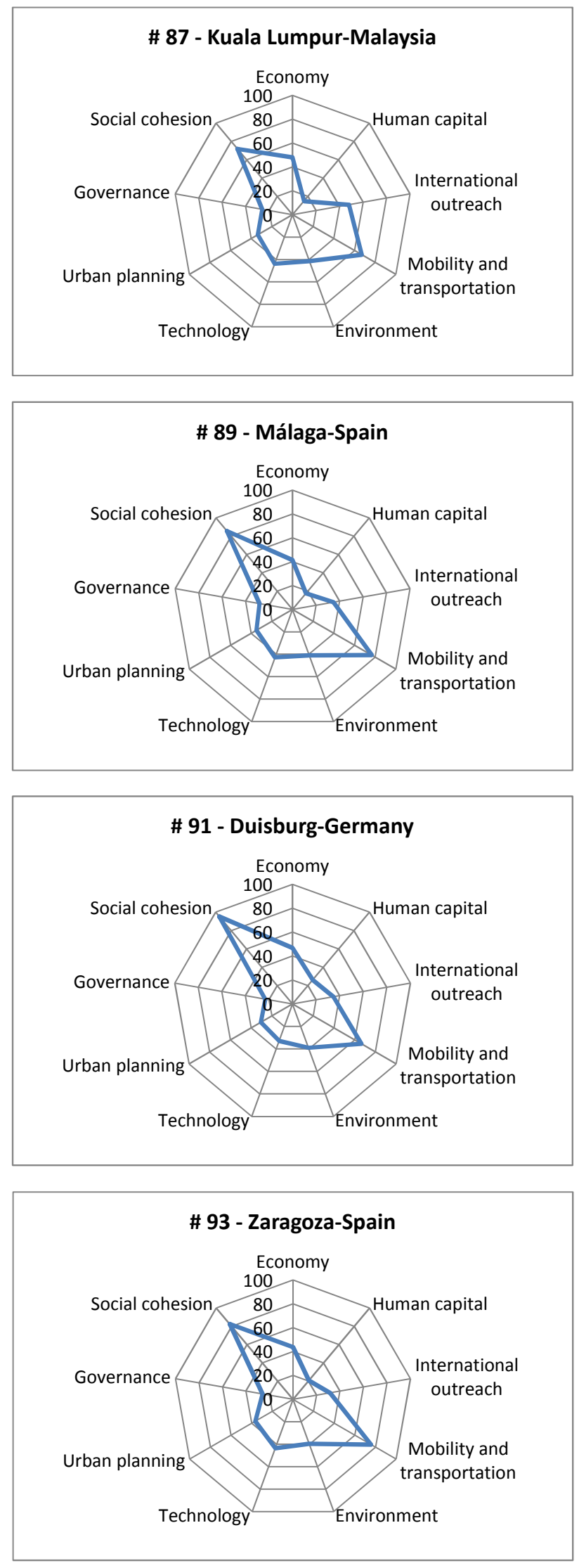
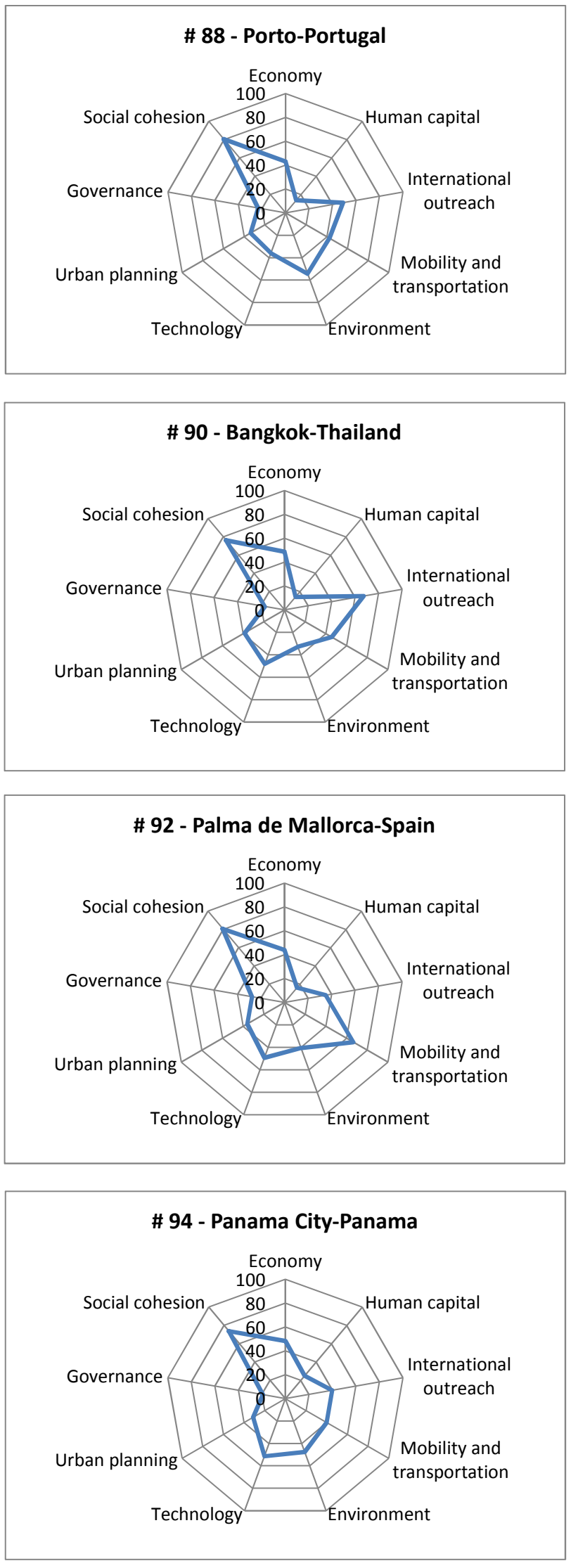

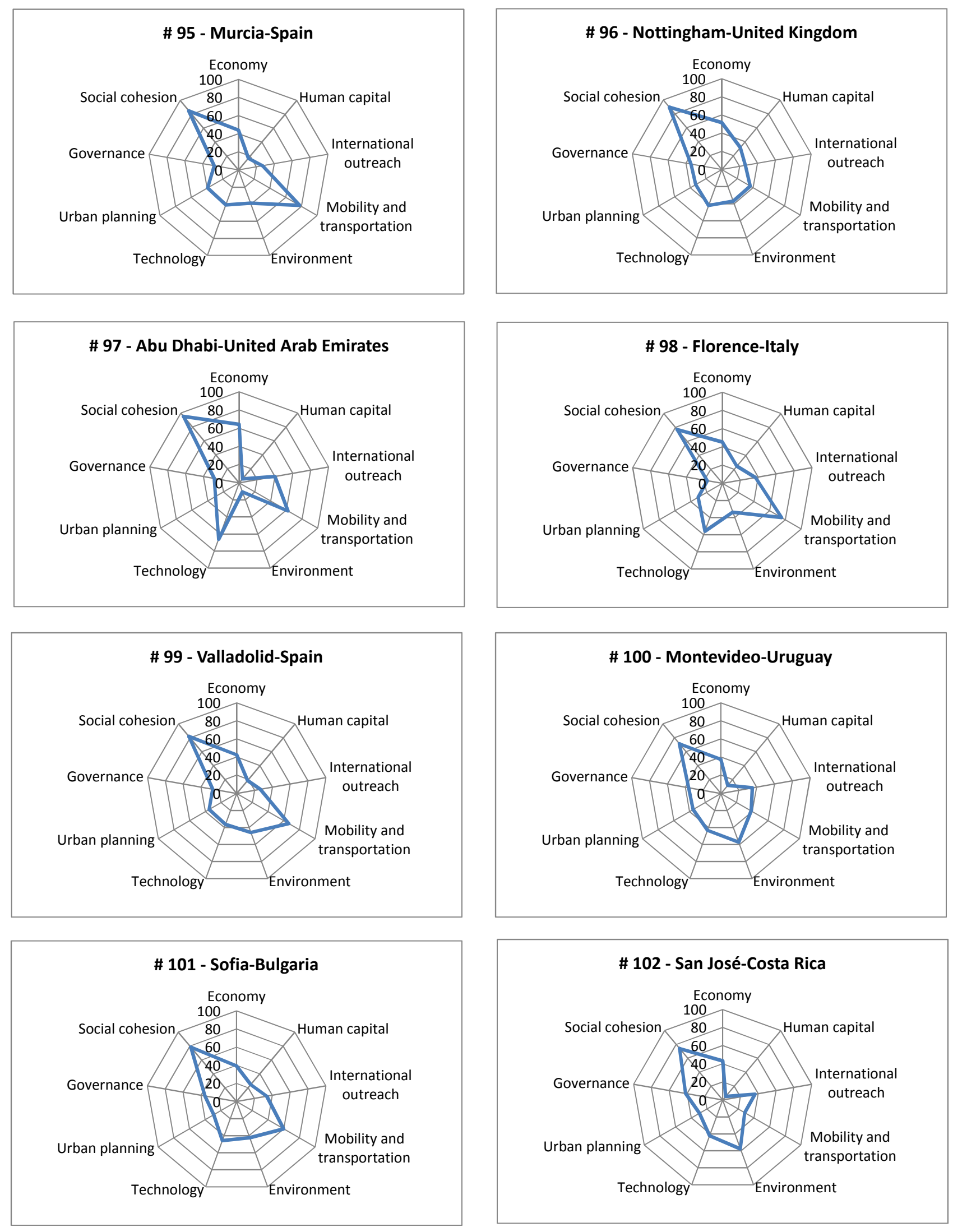

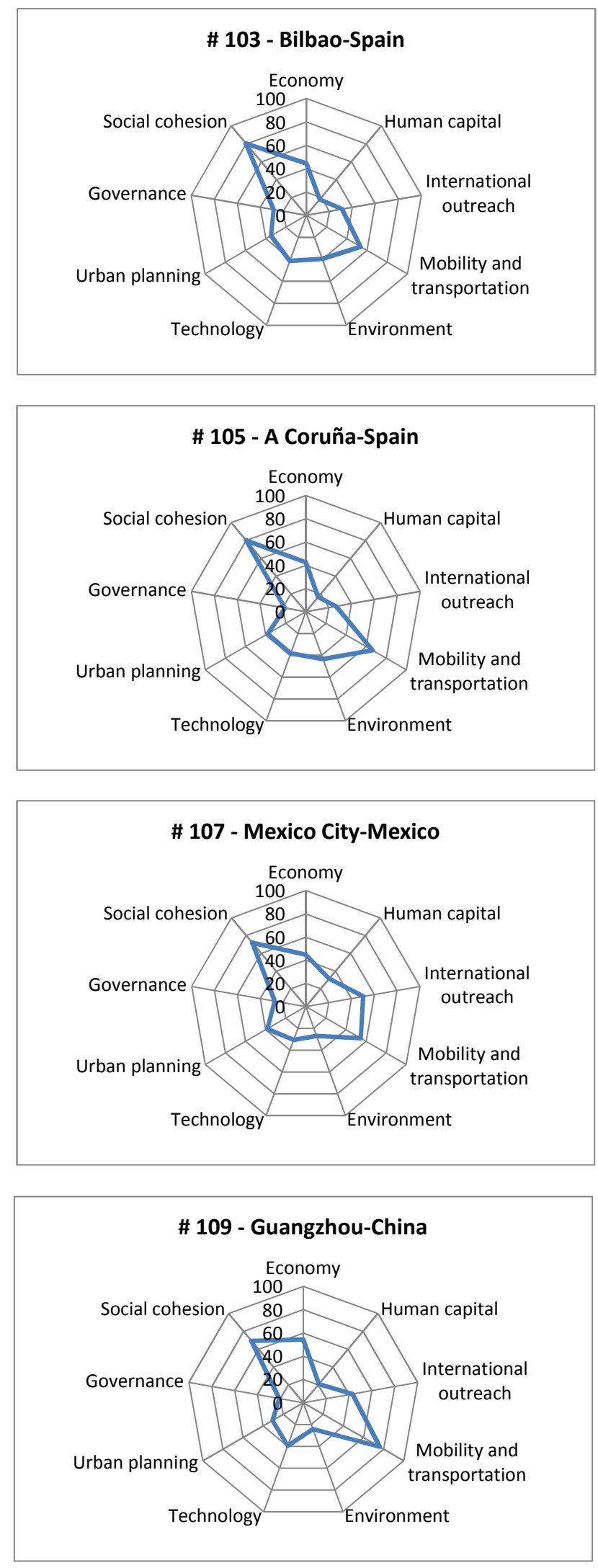
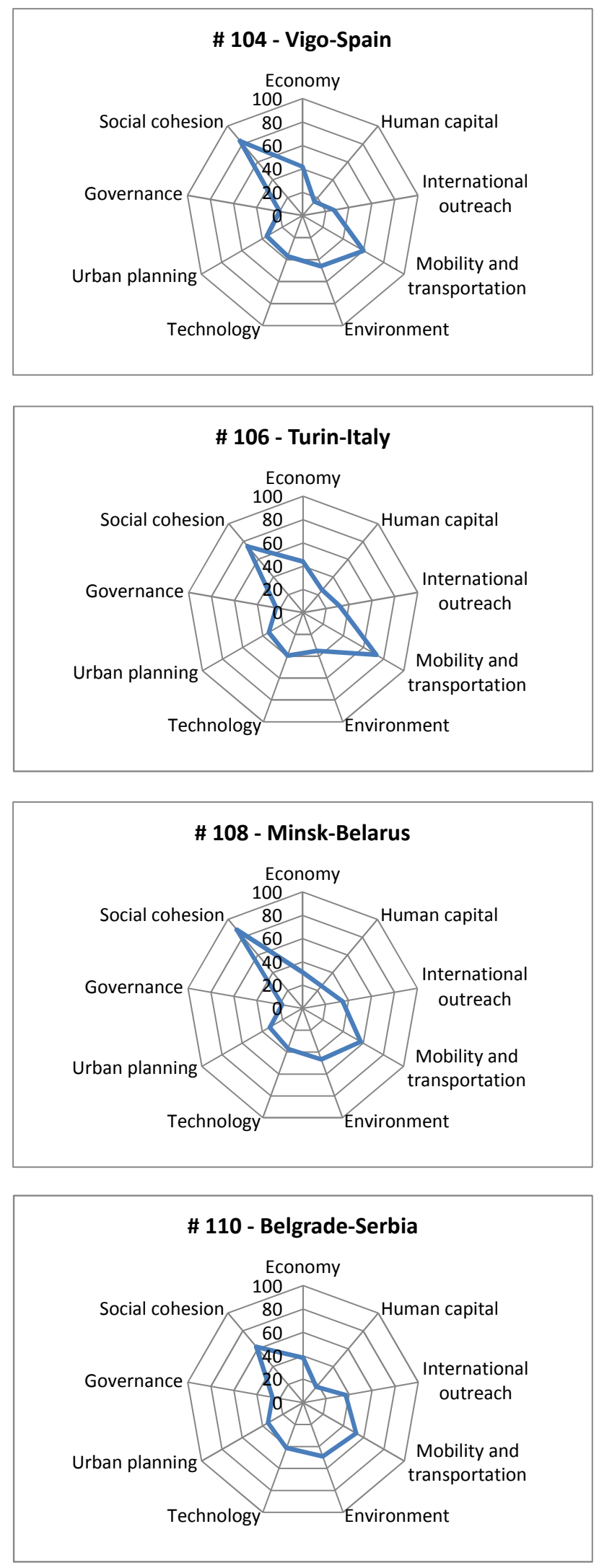

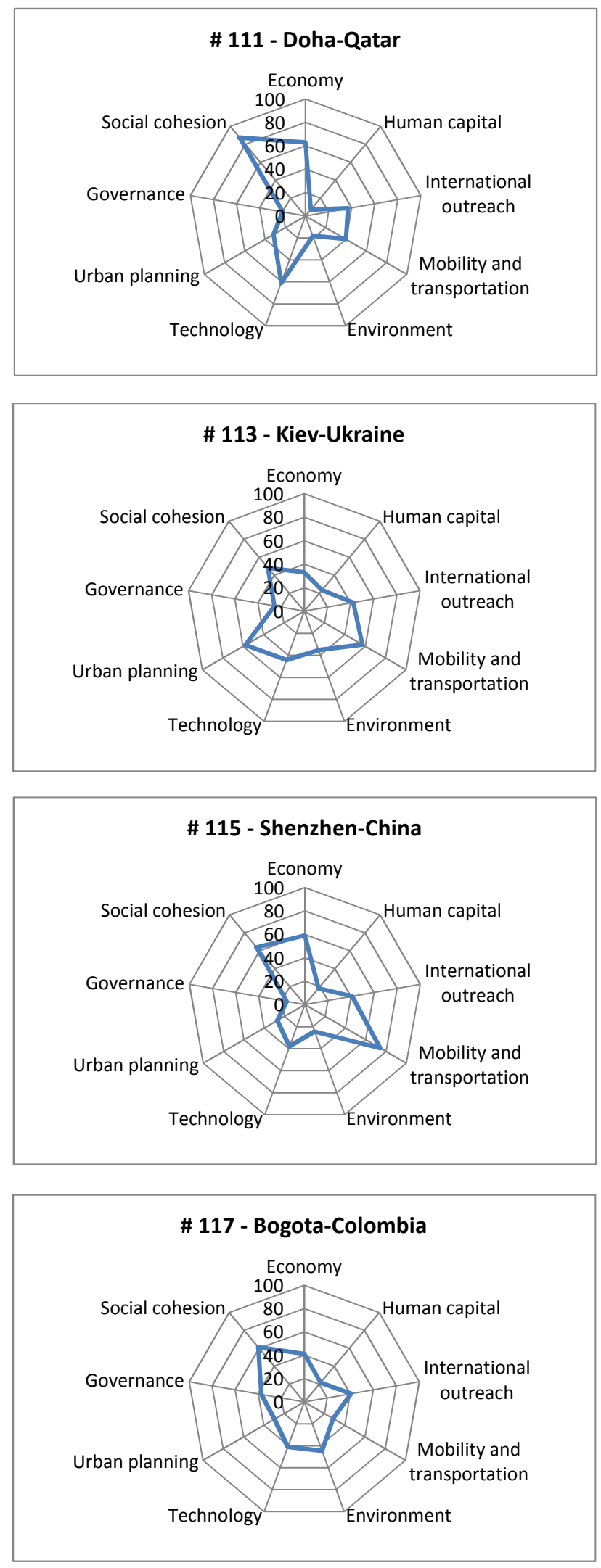
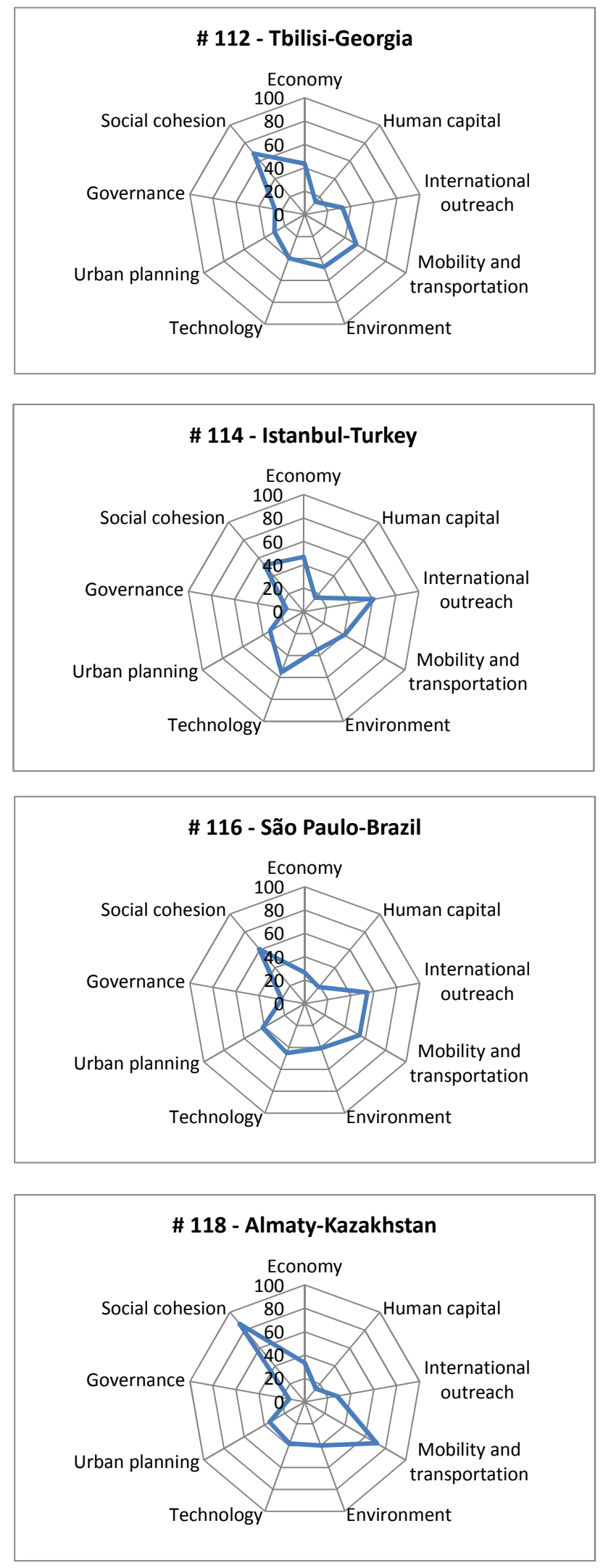

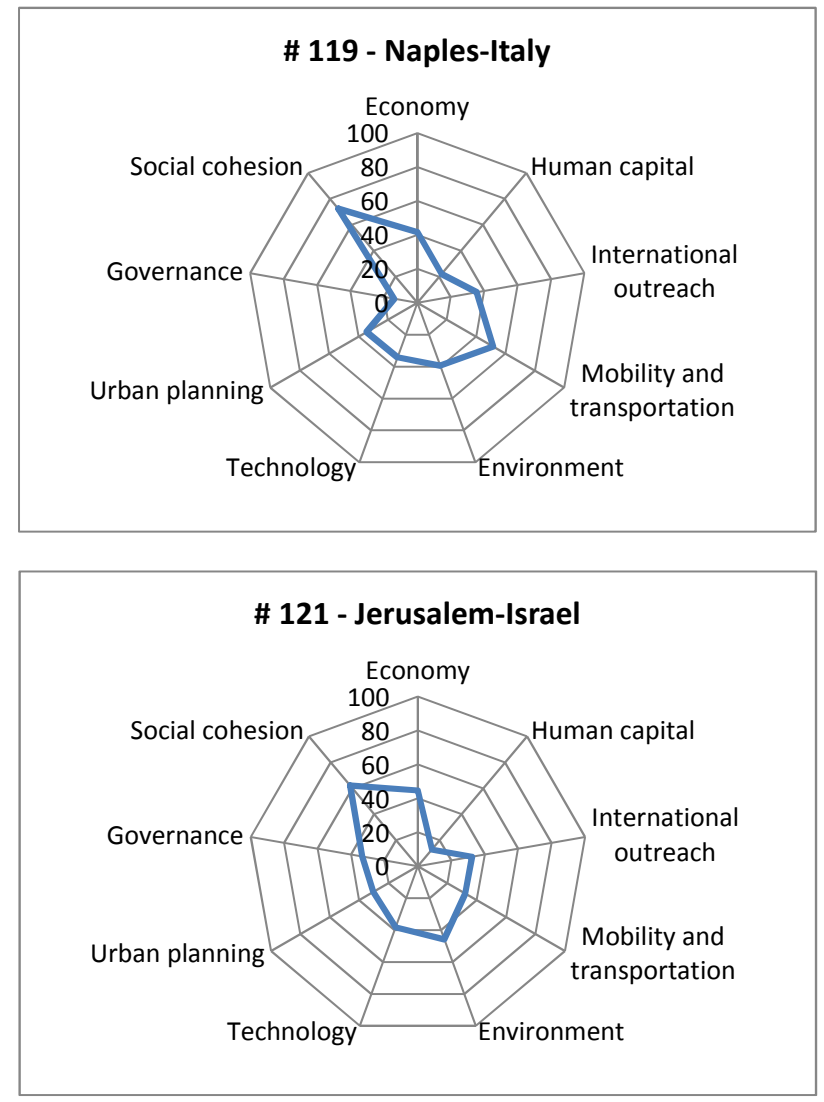

\section{\# 123 - Saint Petersburg-Russia}
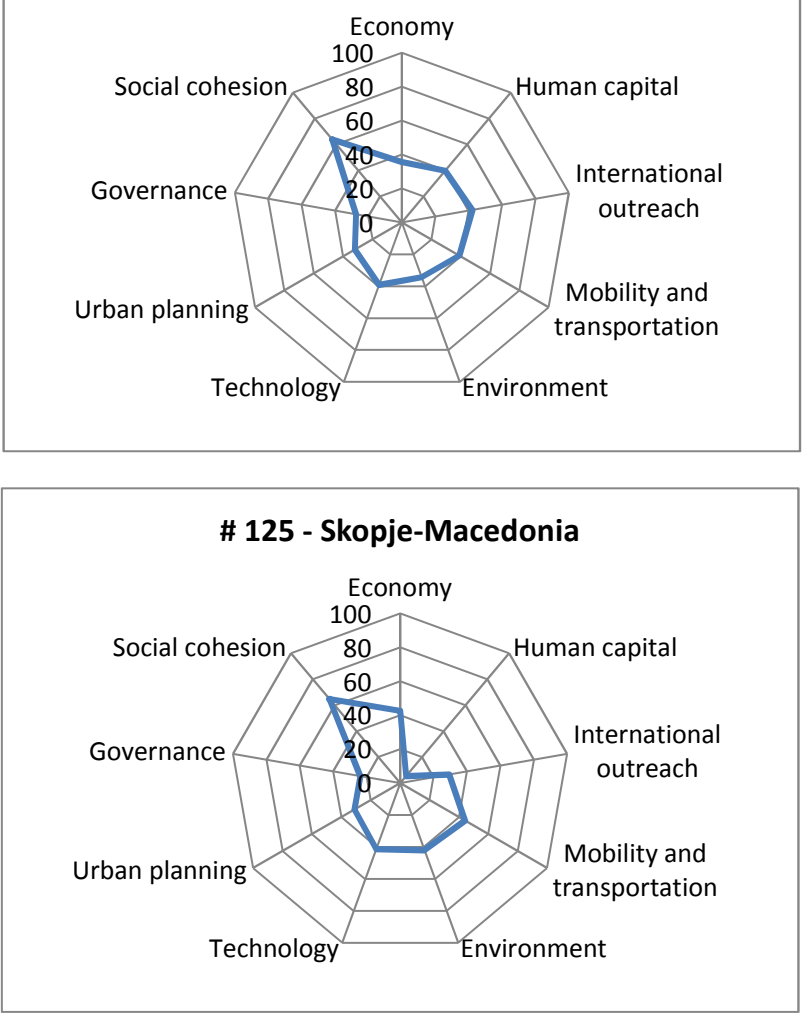
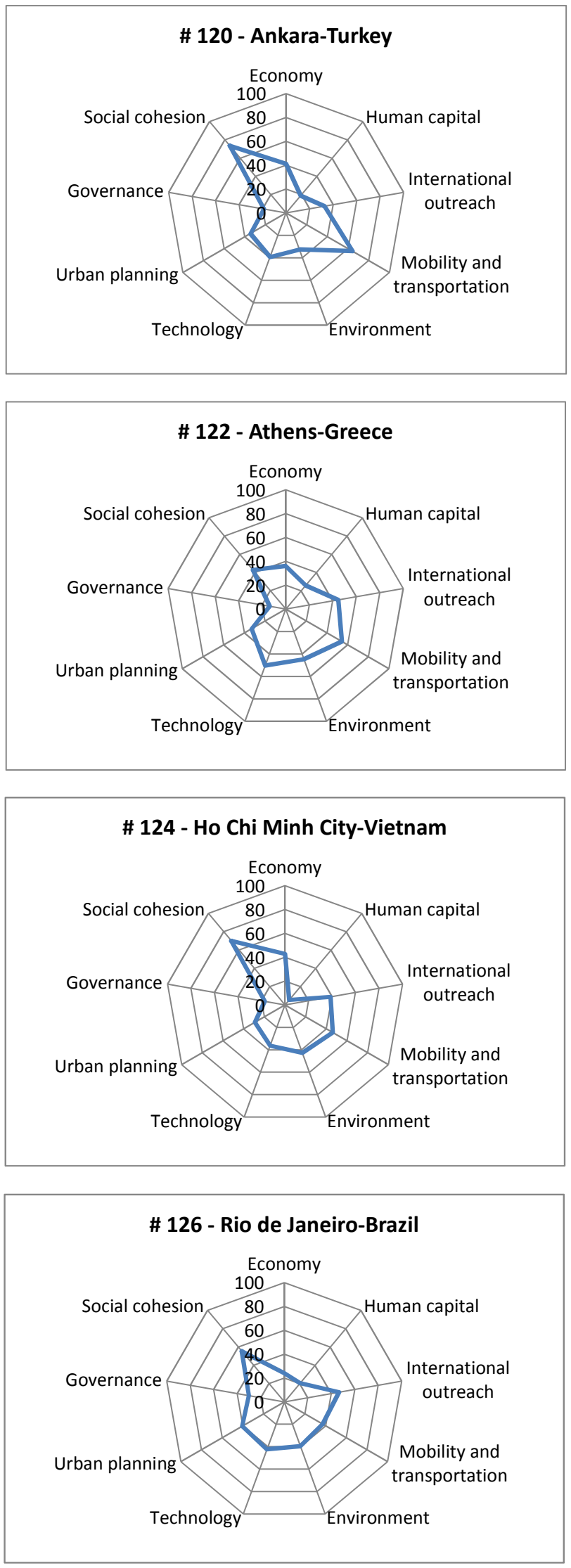

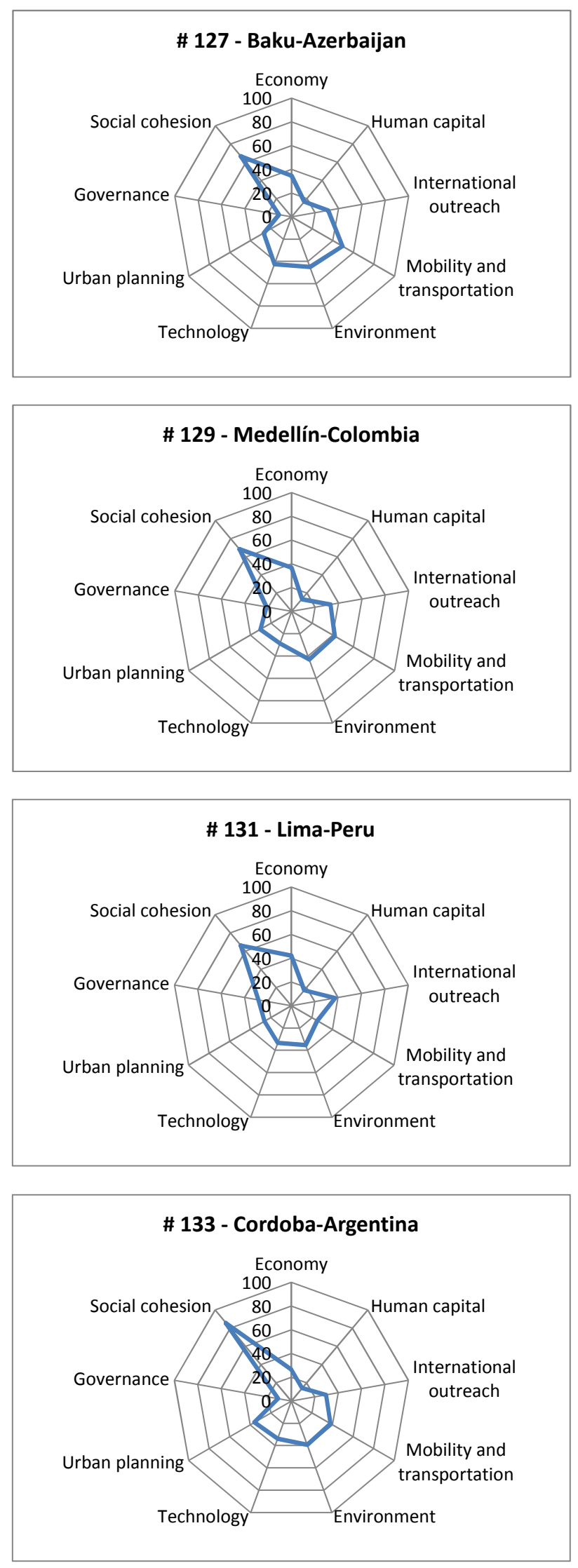
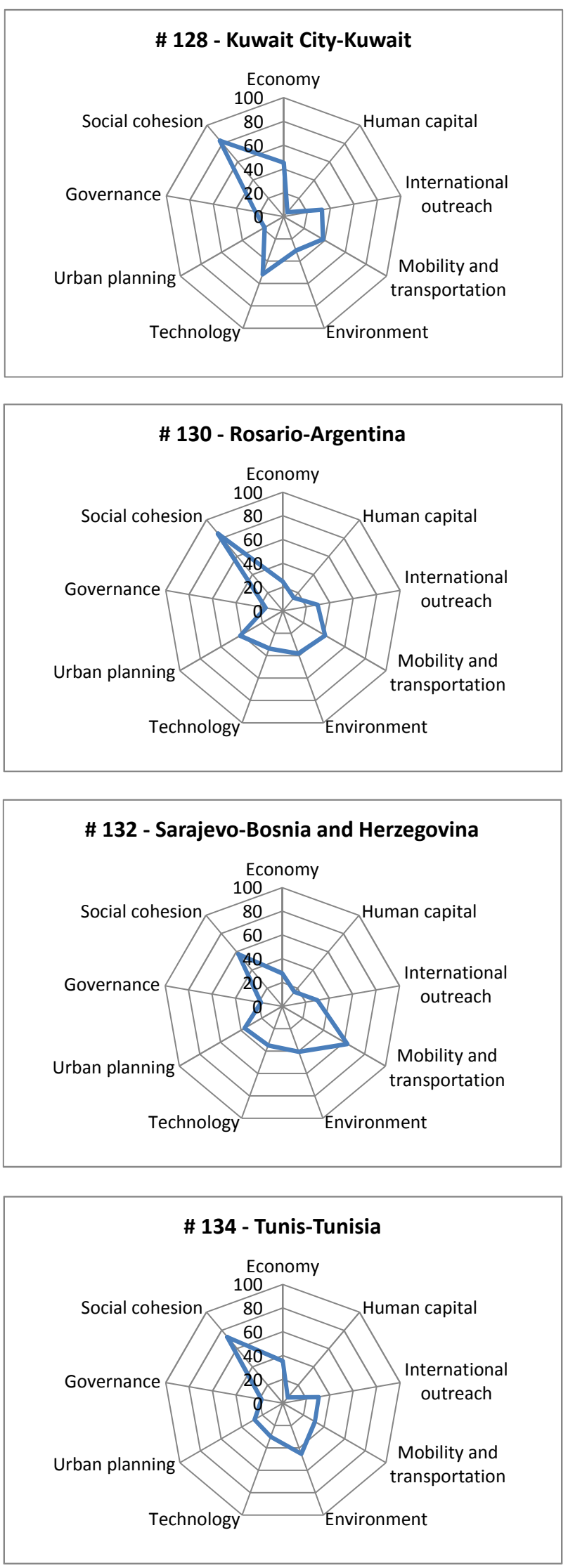

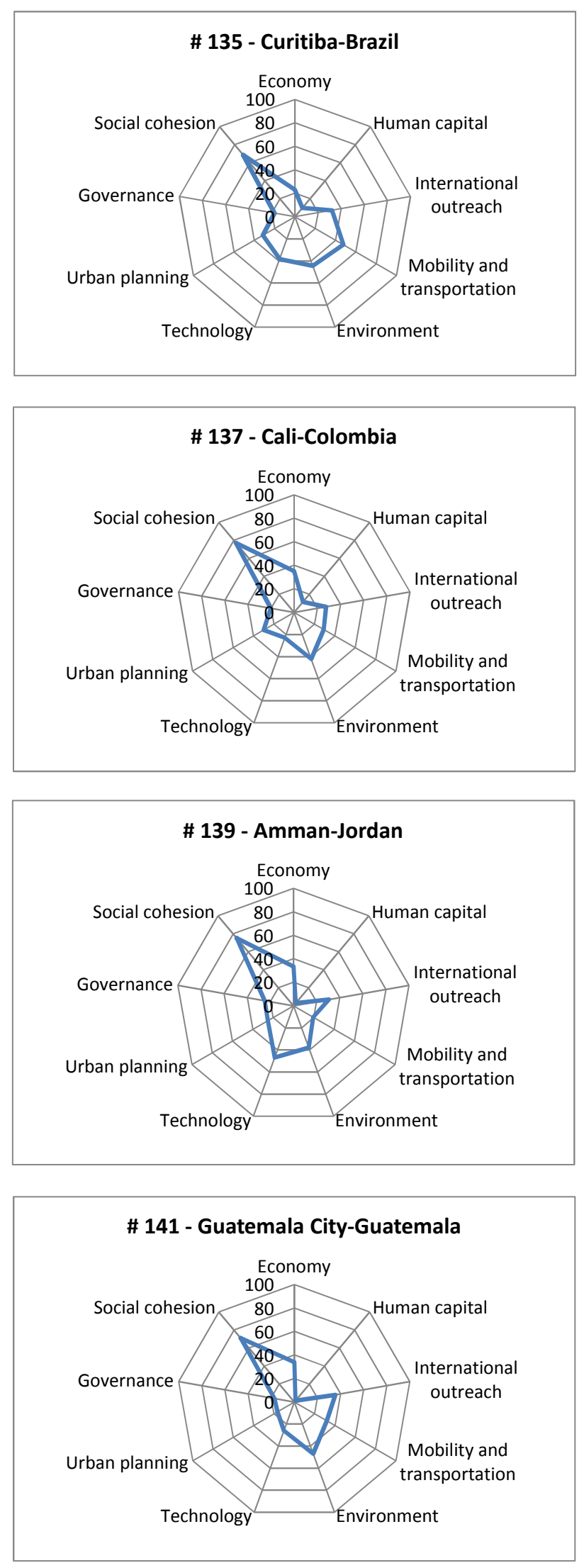
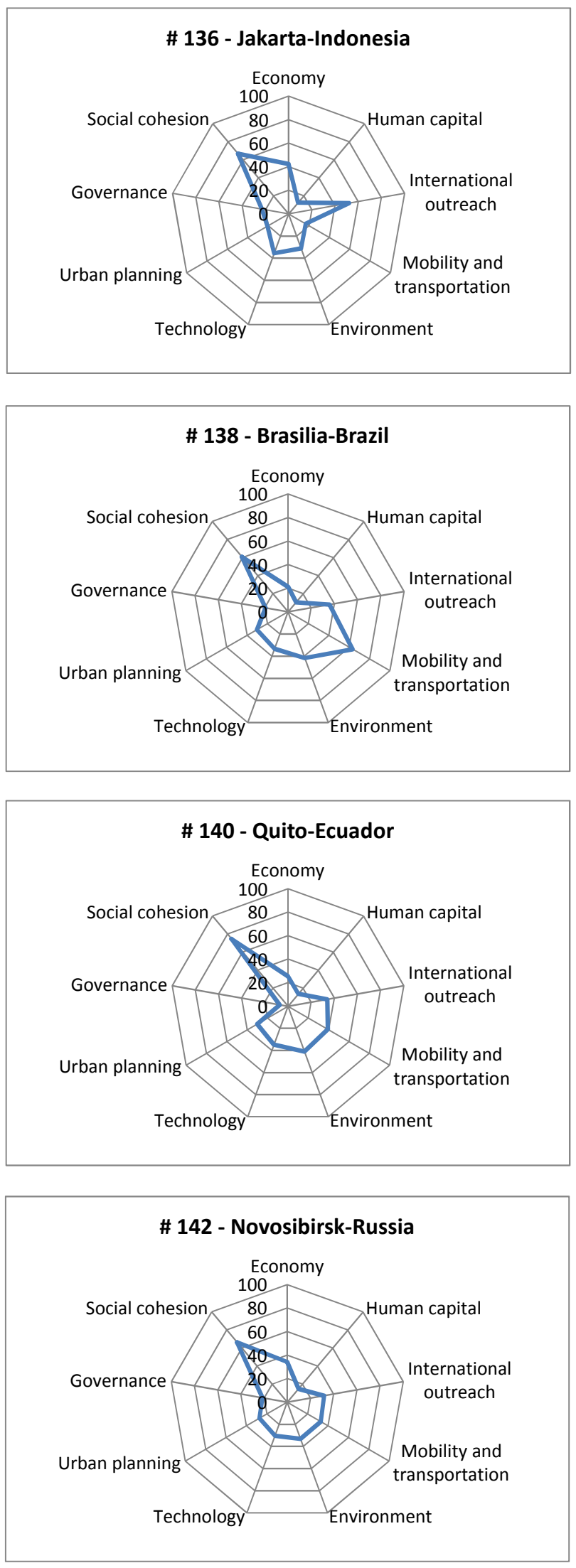

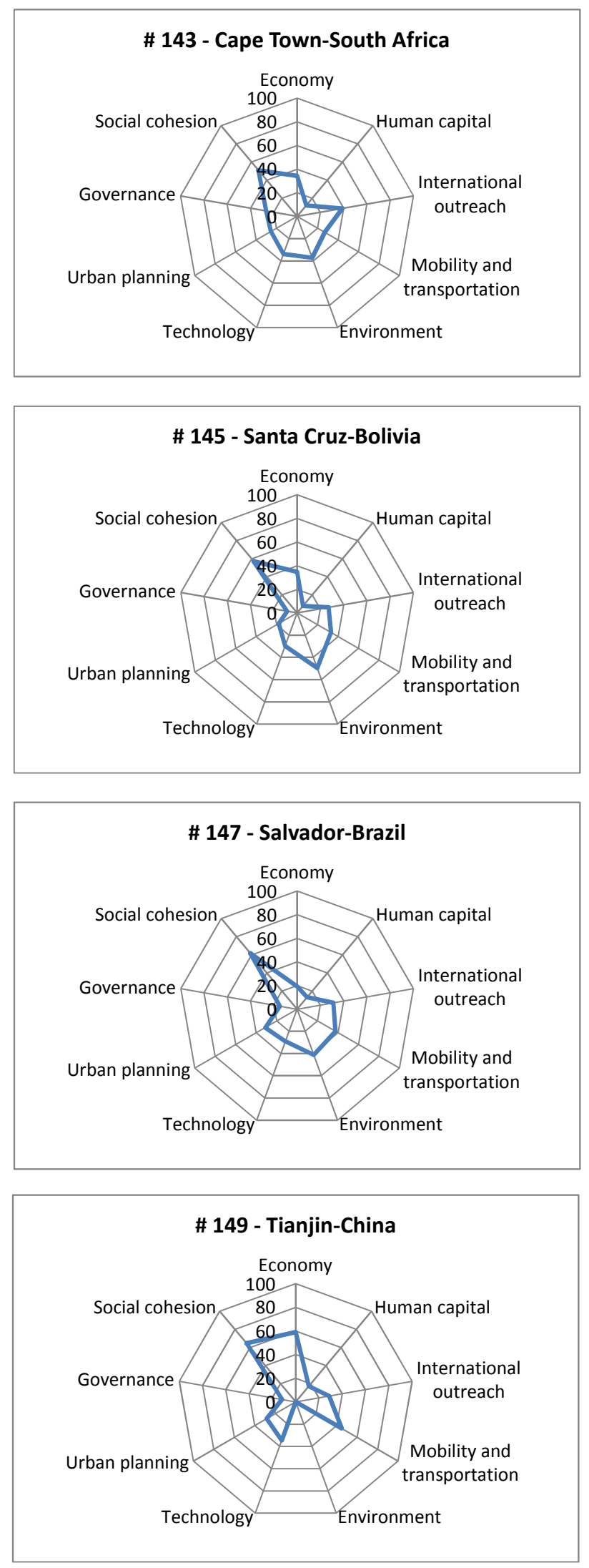
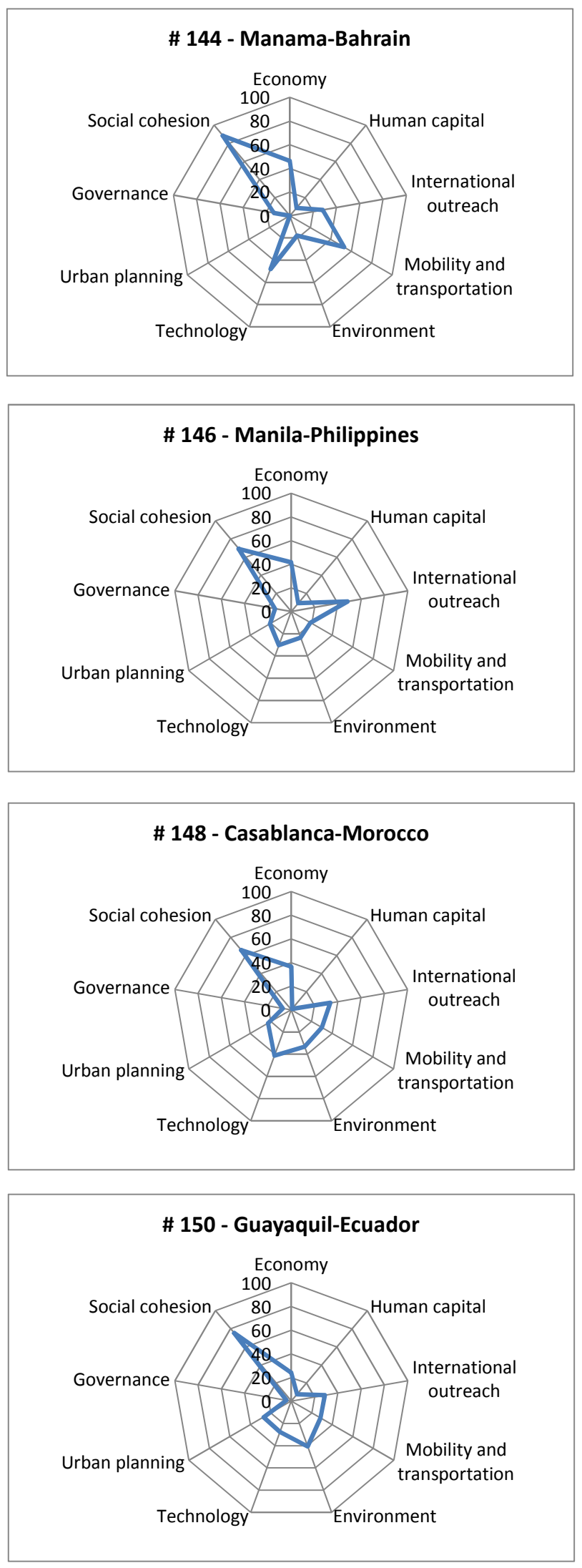

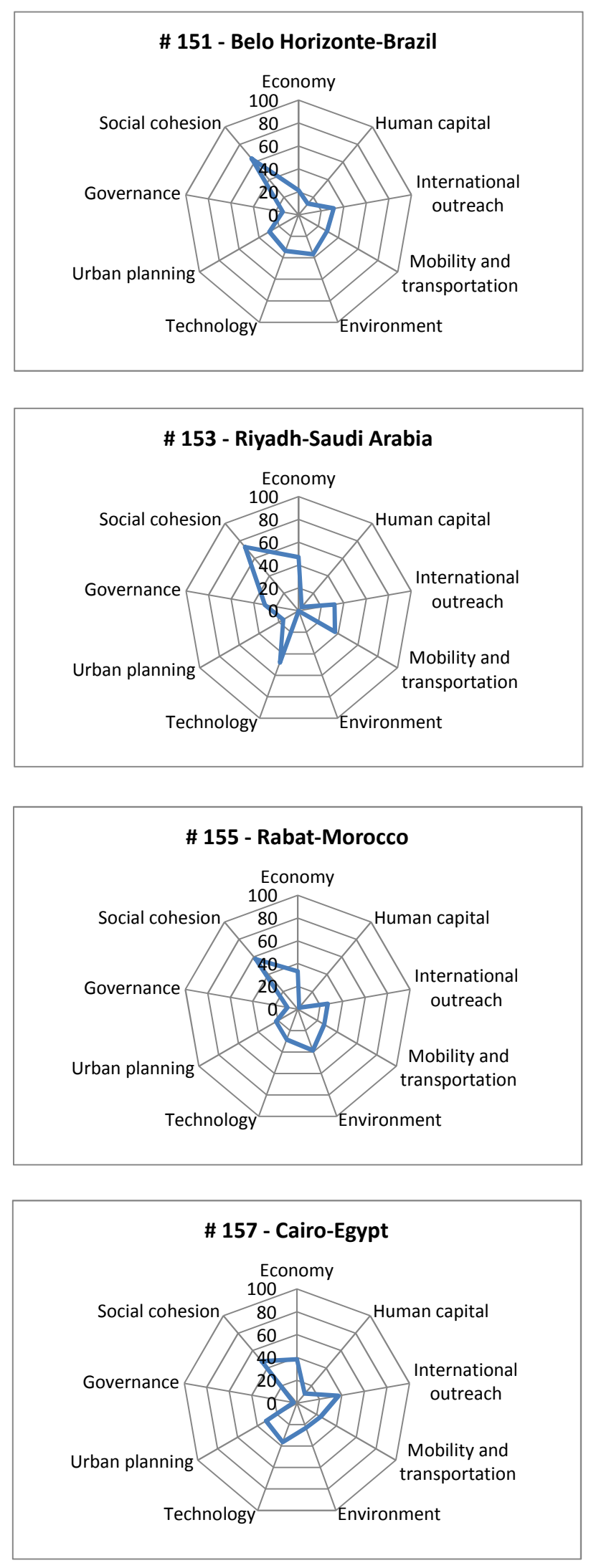
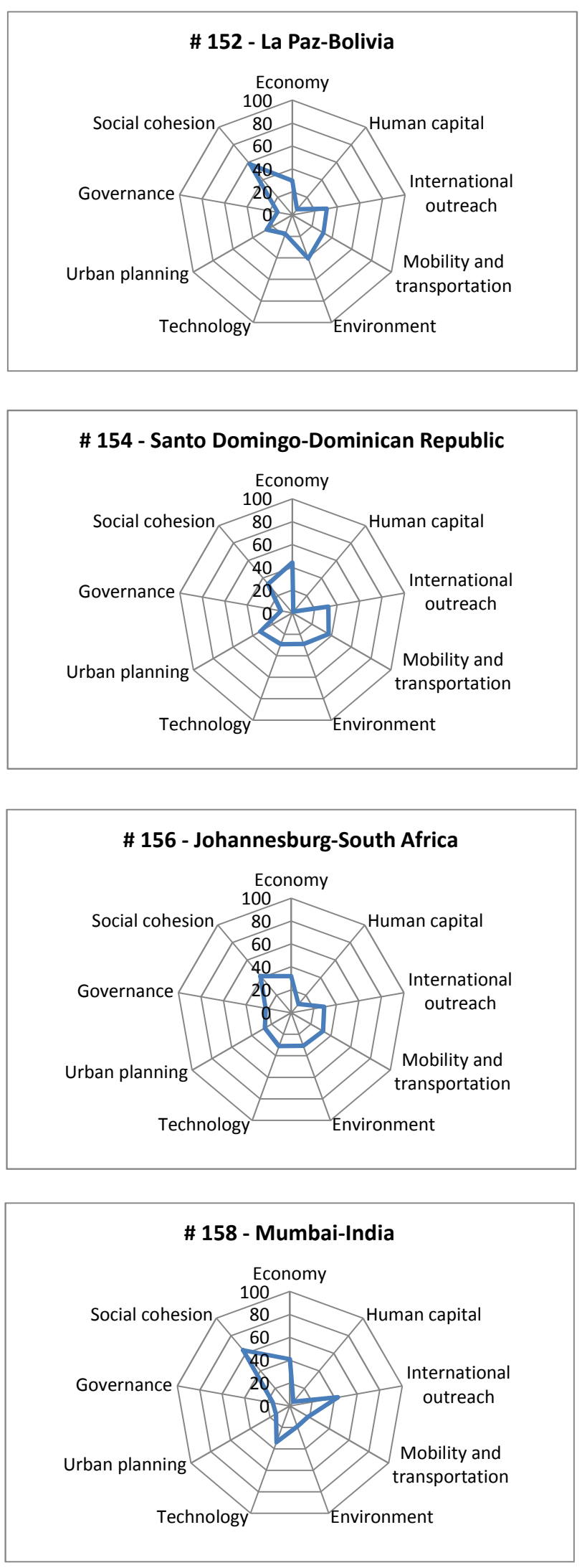

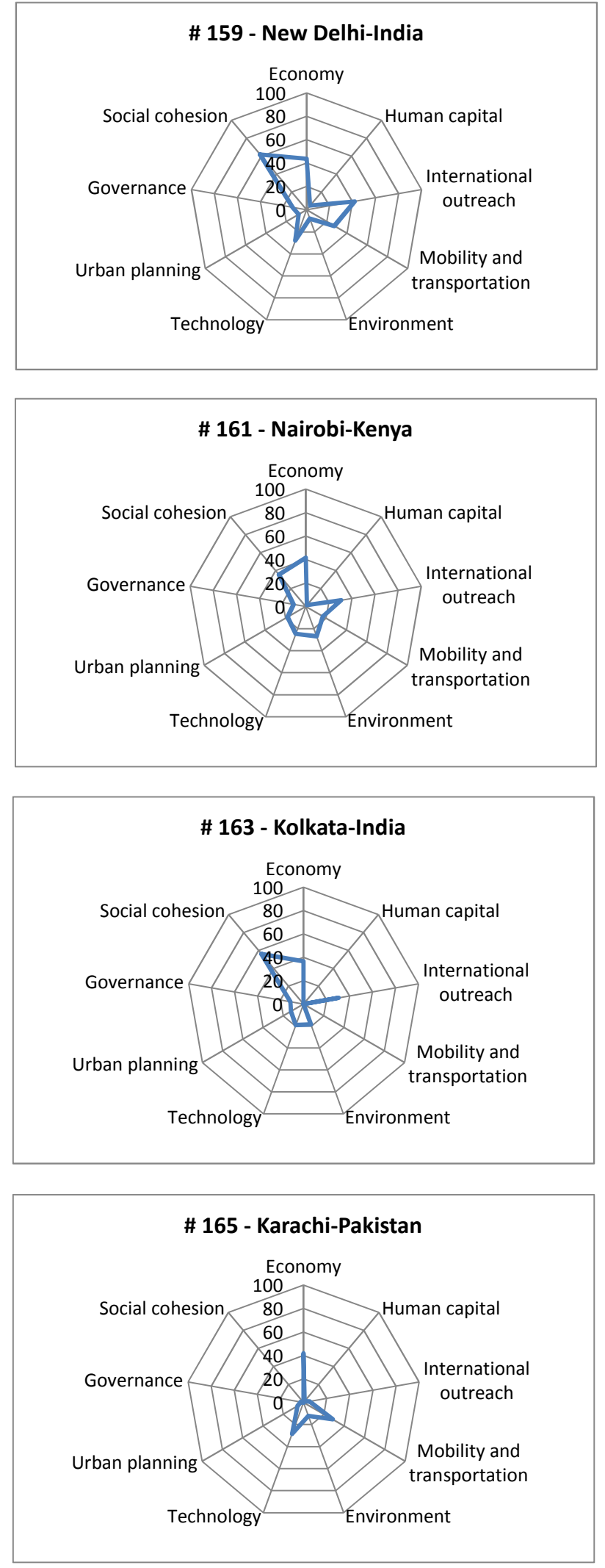
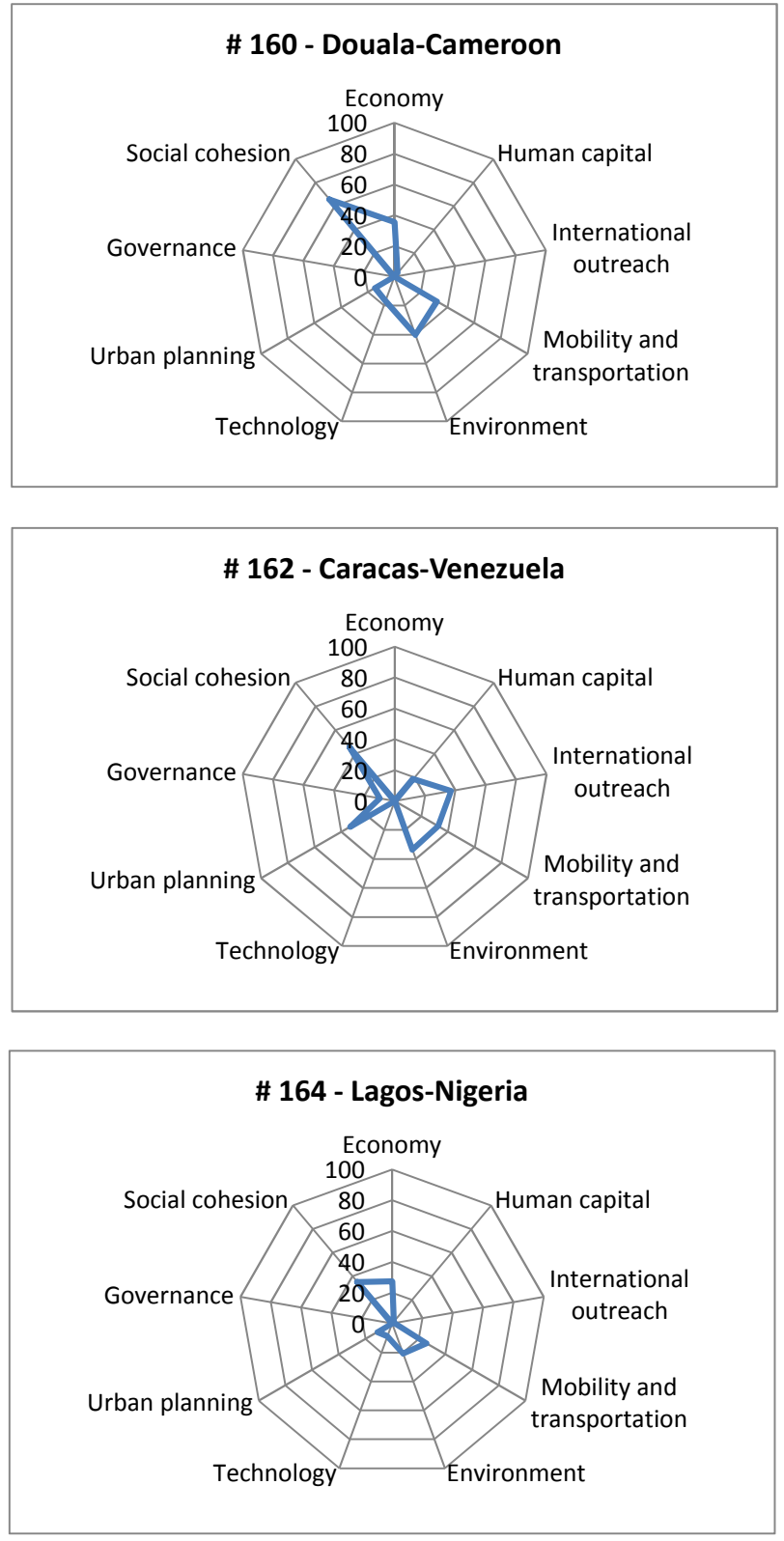


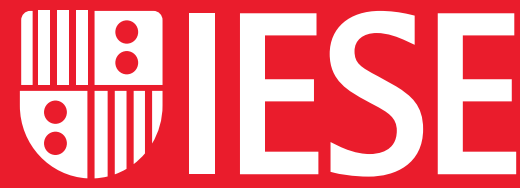 \\ Business School \\ University of Navarra}

\section{A WAY TO LEARN \\ A MARK TO MAKE \\ A WORLD TO CHANGE}

\footnotetext{
Follow us

(in IESE Business School

(f) IESE Business School

(2) iesebs

Youb iese
}

\section{Barcelona}

Av. Pearson, 21

08034 Barcelona, Spain

(+ 34) 932534200

\section{Madrid}

Camino del Cerro

del Águila, 3

28023 Madrid, Spain

(+34) 912113000

\section{New York}

165 W. 57th Street

New York,

NY 10019-2201 USA

(+1) 6463468850

\section{Munich}

Maria-Theresia-Straße 15

81675 Munich, Germany

(+49) 8924209790

\section{Sao Paulo}

Rua Martiniano de

Carvalho, 573

Bela Vista

01321001 Sao Paulo,

Brazil

(+55) 1131778221 